\title{
The Latin Manuscript about the Dutch War and Its Translation in English
}

\author{
Veronie Meeuwsen (ed.)
}

\section{Transcription of the manuscript}

The manuscript could not be transcribed completely because it is partly damaged. At the bottom of the folios we find large blank spaces as a result of moisture, so that these parts of the text are hard or even impossible to read and to transcribe. Still the text that remains is valuable and provides a good idea of what Maria Petyt has written about her experiences during the Dutch War.

The transcription of the text provides the basis for a critical reading. I have tried to provide a transcription that is as literal as possible from the original text. Please keep in mind the following stylistic guide. The summaries of Michael of St. Augustine are indented texts as in the manuscript. Where the text is impossible to read this is indicated with dots: .... Uncertainties in the text I indicate with square parentheses: [ ]. Augmented texts on grounds of probability are indicated by pointed parentheses: $<>$. Line numbers between square brackets [ ] are added to make it easier to refer to the original text. Lines as in the original text, are separated by slashes (/). Folio breaks have an extra double slash $(/ /)$ indication. Other signs like parentheses, underlinings etc. are literal reproductions of the text in the manuscript. The punctuation is adapted to modern usage. Abbreviations are written out in full.

I have transcribed all the text as literally as possible. However, I have some remarks about the transcription of some particular letters. For the letters $i$ and $u$ both as vowel or consonant the notation of the manuscript is followed, which makes clear that the scribe does not differentiate between $i / j$ and $u / v$, which is usual in Latin texts from that time. With capitals it is the other way around: $I / J$ and $U / V$ are respectively written as $J$ and $V$.

* Special thanks to dr. Rijcklof Hofman for his help with the transcription.

(C) VERONIE MEEUWSEN (ED.), 2015 | DOI 10.1163/9789004291874_009

This is an open access chapter distributed under the terms of the Creative Commons AttributionNoncommercial 3.o Unported (CC-BY-NC 3.0) License. 


\section{Vita Venerabilis Matris Mariae a Sancta Theresia}

Rome, Arch. Carm. Post. III, 7of.3or-49v

3or

[1] Iussu Dei sequentia scribit Suo Patri Spirituali suo secreto, quamdiu / ipsa uiuet. Sic autem incipit 7 Nouembris $1672 . /$

Sit nomen Domini benedictum ex hoc nunc et usque in saeculum. / Quantum possum percipere et iudicare de mandato diuini Amatoris mei, arripui calamum in manu, ut an- / [5] notem sequentia, cum quasi mandato, quod debeant manere secreta et occulta sub meo patre spirituali / solo, nulli alteri quidquam de illis notificando directe uel indirecte, quam diu ego uixero, ne malignus spi- / ritus inde sumat instrumentum, quo me oppugnet tempore tentationis. /

Post mensem internae derelictionis redit spiritus trahitur ad intimam quietem / A Dilecto possidetur, et eum possidet. Renouatur in ea spiritus orandi pro Rege / [10] Galliae, et amor maternus cum confirmatione praeteritorum. /

Cessante statu internae derelictionis et afflictionis, quem per litteras datas 16 et 17 octobris 1672 / Reuerentiae Vestrae notum feci, qui durauit circiter per 


\title{
Life of the venerable Maria of Saint Teresa ${ }^{1}$
}

\author{
Rome, Carm. Archive, Post. III, yo
}

3 or $^{2}$

At the command of God, she writes the following to her spiritual father, binding him to secrecy for as long as she would live. So she begins on the 7th of November 1672 .

The name of the Lord be praised from now and forever more. As far as I can perceive and judge the mandate of my divine Beloved, I have taken my pen in hand, to note the following, with the instruction that it should remain secret, and known to my spiritual father alone. It may not be disclosed to anyone else, directly or indirectly, as long as I live ${ }^{3}$, so that no evil spirit may derive from it anything with which to attack me in a time of trial.

After a month of inner dereliction the spirit turns back. She is drawn to the most intimate peace, she is possessed by the Beloved, and she possesses Him. The spirit of praying for the King of France is renewed in her, as well as her motherly love with the confirmation of the previous things.

When my state of inner dereliction and desolation ended - a state that I have made known in letters of the 16th and 17 th of October to Your Reverence, a

1 I thank Miceál O'Neill O. Carm. and Joseph Chalmers O. Carm for their help as native speakers with the English translation and also Dr Antoine Jacobs for his support in historical questions.

2 The manuscript is not bound in the original sequence. The original sequence should be as follows: First part: f.38r-41v, a half section: concerning the period of May 1672. (38r 1-3 can be seen as an introduction to the entire text about the Dutch War. It is the only place in the text where Maria Petyt is described and introduced with all her names and titles); Second part: $\mathrm{f}$. 3or-33v, a half section: concerning the period of 7-15 November 1672; Third part: f. 42r-49v, a complete section, concerning the periods: a. 21 November -17 December 1672 (f. $42 \mathrm{v}-45 \mathrm{v} 3$ ); b. New experiences in February 1673 (f. 45v); c. And 28-29 June 1673 (f. 45v-49v); Fourth part: f. 34r-37v, a half section: concerning: a. 4 July $1673-15$ January 1674 (f. $34 \mathrm{r}-37 \mathrm{v}$ ); b. A last mystical experience on $24 / 25$ August 1676 (37v). In this original sequence the chronology of the text is correct. For this edition of the text we have chosen to keep the text in the sequence in which it has been preserved. See also the article of Giovanni Grosso, p. 83-91.

3 Here Maria explicitly asks Michael to keep her letters secret, for as long as she lives. See also the article of Esther van de Vate, 92-118. 
mensem, euigilauit in me et resuscitatus est nouus spiritus / qui aliquot mensibus in me quasi dormierat, et euanuerat, absque ulla operatione aut perceptione eiusdem / enim ab eo tempore quo rex Galliae recesserat in patriam suam. /

[15] In primis Dilectus me introsumpsit in se cum perceptibili et amabili obumbratione alicuius luminis / et splendoris suae diuinitatis, quod lumen illustrabat et penetrabat omnes animae potentias. /

Aliquot diebus fui tracta ad profundam intimam quietem in Dilecto quasi in somno amoris cum / euanescentia omnium, quae non sunt ipse, nihil aliud in me percipiendo quam eius praesentiam. /

Aliquando eram quasi ab ipso possessa, ipse possidebat me et ego possidebam ipsum tunc iterum mihi infun- / [20] debatur spiritus orandi pro Rege Galliae, sicut antehac, qui spiritus ualde uinaciter et efficaciter / incipiebat operari ad eius succursum, et assistentiam, et omnes praeteritae internae d.... icticones illumi- / nationes amorosae ad illum Regem inclinationes, maternus animus etcetera iterum dabantur cum / noua confirmatione ueritatis. /

Dilectus eam ponit ad latus Regis istius, ut eum iuuet ..............t / [25] benedictionem super illum et exercitum. Mira facit in [structu] ...... circa Regem / cuius intentionem intellegit esse Deiformem. /

Percipiebam, quod Dilectus me constitueret ad latus huius Regis, et quod Dilectus me faceret ad illum / inclinari, quasi debuissem cooperari cum isto Rege: benedictionem quam iubente Dilecto antehac ipsi dederam / iterato impertiebar super ipsum et super illius exercitum cum efficaci et uiuaci amore /

[30] Ab illo tempore continuo sine cessatione mihi remanet spiritus orandi pro ipso. Quidquid Dilectus uidetur / desiderare, ut faciam et offeram sponte et ultro intus in fundo dictatur et per spiritum ...... mandatur / cum uiua fide, firma fiducia et forti d........e oblationes quas debeo facere pr...... hauriebam / omnes ex Dilecto Iesu meo Deo homine. Omnes factae communiones, quas facio, sunt .......o ipso sola ...nt / possit acquirere uirtutem, et gratiam, qua possit superare inimicos suos. / 
state that lasted for about a month - a new spirit awakened and rekindled in me, that for a few months so to speak had been sleeping and had disappeared without any effect or perception of the same, namely right from the time when the King of France had returned to his homeland. ${ }^{4}$

In the beginning, the Beloved drew me inward with a noticeable and pleasant dimming of the light and with the radiance of his divinity, a light that lit up and penetrated all the powers of my soul.

For some days I was drawn to a profound and intimate quiet in the Beloved as a sleep of love with the passing of all things that are not Him, perceiving nothing in me other than his presence.

Sometimes I was as if he had taken possession of me. He possessed me and I possessed him. Then again the spirit of prayer for the King of France penetrated me, as before. A spirit that began to work vividly and powerfully, for his assistance and support, and all those past inner ... illuminations, loving tendencies towards that King, a motherly spirit etc. were again ... given with further confirmation of the truth.

The Beloved places her on the side of that King, to help him ... and to give his blessing to him and his army. She marvels at ........ the King whose intention she understands to be Godlike.

I perceived that the Beloved put me on the side of this King, and that the Beloved made me inclined towards him, as if I had to cooperate with that King. The blessing, which I on the Beloved's demand had given him in advance, I again bestowed on him and his army with powerful and vibrant love.

From that time on the spirit of praying for him stays with me constantly, without interruption. Whatever the Beloved seems to require me to do and to offer voluntarily and on my own accord, that is in my depth commanded, and by the spirit ... entrusted with lively faith, firm confidence and powerful ... The sacrifices I must make ... I drew all from my Beloved Jesus, God and man. All communions made, those that I make ... for him alone ..., might obtain a power and grace, by which he might overcome his enemies.

4 At 7 April 1672 Louis XIV declared war on the Republic of the Seven United Provinces and quickly marched by way of the Prince-Bishopric of Liège and the Prince-Bishopric of Münster. After having conquered Utrecht, the French advances were stopped by deliberate inundations along the Dutch water line. A couple of weeks later Louis XIV handed over the command to Marshal Luxembourg and left the Republic with 20,000 soldiers. 
[35] Quippe interius intelligo eius animi decretum et expositum, ac zelum circa Hollandiam esse plane Deiformem / nihil intendendo nisi honorem et gloriam Dei, ac conuersionem animarum et multi eum falso accusent et ..... / nentur qui spargunt contraria iudicia: uerum alia sunt iudicia Dei, alia hominum; ueritas semel patebitur / quia Deus erit cum ipso, et est cum ipso, et uidebimus potentiam Dei in ipso et cum ipso / operari. //

\section{$30 \mathrm{~V}$}

[1] Intelligit Iesum diligere istum Regem et ipsa eum diligit ut filium, et omnes / eius milites ut filios, circa quos materne occupatur, exercitum amando, / Angelos mittendo etc. /

Vidi et intellexi quod ille Rex sit a Jesu Dilectus, et per eumdem amorem etiam a me diligitur / [5] uelut ..[aharut] filius, quem diligit Iesus; ideo quando pro ipso oro, dico ad Iesum; Dilecte, adiuua / tuum et meum filium, tua uirtute sapientia et amore; et inde resultat ulterior dilectio, quae fluit / ad omnes eius subditos et milites, quasi omnes essent mei filii. /

Maternum meum cor et affectus ualde bene circa illos fertur et operatur, praesertim circa infirmos / .....sos ut eos commendem Dilecto meo quatenus eos uelit sanare confortare etc. ut sint apti et / [10] parati ad proelium; alius spiritus quasi igne amoris accensus dat Regi et militibus animos ne timeant / hostes suos, ut eos in nomine, et ad amorem Christi generose aggrediantur; ipsis ex parte Jesu / addicendo uictoriam. /

Spiritus amoris stabiliter se tenet ex parte Regis Franciae, cum tota anima, propensione, et / uidetur illum exercitum quasi supercomplecti, et supercomprehendere, quasi cum uirtute aliqua distri- / [15] butiua quae prouenit et fluit ex meo corde et intimo amore; spiritus amoris facit etiam instantias apud / [Dilectum] ut uelut mittere multitudinem Angelorum in eorum subsideum et assistentiam. / 
For I understand inwardly the decision and the conviction of his soul, and that his zeal for Holland is clearly Godlike, intending nothing but the honour and glory of God, and the conversion of souls. And I understand that many people falsely accuse him ... and there are those who spread opposite judgments. But the judgments of God are unlike those of humans. The truth will be revealed once, that God will be with him and is with him and we will see God's power working in him and with him.

3ov

She understands that Jesus loves the King and she also loves him as her child, and all his soldiers as her children, about whom she is worried like a mother, while she loves the army, and sends angels etc.

I have seen and understood that the King is loved by Jesus and by the same love he is also loved by me ... like a child whom Jesus loves. So when I pray for him, I say to Jesus: "My Beloved, help your child and mine, with your strength, wisdom and love." And from there results a further love which flows to all his subordinates and soldiers, as if all of them were my children.

My motherly heart and feelings are gathered very strongly around them and especially around the weak ... to recommend them to my Beloved, so that he might heal and comfort them etc, in order for them to be equipped and ready for battle. Another spirit ${ }^{5}$ that is as it were kindled by a fire of love gives to the King and his soldiers the courage not to fear their enemies, so that in the name of and for the love of Christ they may go generous (whole-heartedly) towards them, while on the part of Jesus victory is promised to them.

The spirit of love remains firmly on the side of the King of France, with its entire heart and affection, it seems as it were to surround and include the army as a special virtue that comes and flows from my heart and my tender love. The spirit of love also makes intercessions to the Beloved, to send a host of angels to help and support them.

5 Maria distinguishes different spirits in her mind. 
Ex corde diuino fugit aliquam uirtutem, quae ex illa fluit in adiutorium Regis / Galliae, quem asserit uere conuersus, et continuatur spiritus orandi pro illo cum / perceptione diuinae maiestatis ad hoc allicientis cum certitudine boni successus. /

[20] Dum a 2 uel 3 diebus essem in oratione, uidebar ex corde diuino fugere diuinam quamdam uirtutem / et gratiam quae ex eodem uidebatur ulterius fluere in auxilium Regis Franciae. / .......................dicunt Regem Galliae non esse uere conuersum, et quod ipse suscitet Turcas, ut / inuadat Rege.. .......itores Christianorum; si enim hoc sic esset, quomodo Iesus eum tanto uere diligeret / [Regem] ut uide.......................... Iesum eum diligere. /

[25] Die................. Nouembris 1672. continuatur spiritus orationis, ut supra et continuo / ........................................ et uiuacior, cum perceptione suauis diuinae maiestatis intus in me / quae mihi...............................entiam me allicit, et consortat, cum praemagna fiducia, fide et certitudine / de bono successu. /

Hanc suauem maiestatem uideo et continuo gesto intra me siue in oratione siue extra; nihil me / [30] potest impedire [quo minus] illam percipiam: continuo contempler, ei amorose adhaeream ac fami- / liariter et amicabiliter cum illo agam et conuerser; nam spiritus solutus et liber ab omnibus et ab / aliis rebus <in>tactus se potest conseruare intus in castro animae: quasi seorsim ab aliis quae sunt / multiplic. .r corporalia sensualia, et a spiritu non assumpta, uel permissa; nam omnes / praedictae.................. spiritus amoris sunt condita, et penetrata unitate Dei et consequenter / [35] sine medi ........ est unus et idem Spiritus Dei qui facit omnes istas diuersas operationes /

$<$ Co $>$ ntra naturae inclinationem a Deo mouetur, ut oret pro successu / [Re] gis Galliae, cum assecuratione, quod Deus illi faueat, et quod ille / praeualeat, contrarios exercitus reputat, ut muscas: spiritu circum- / plectitur exercitum Francorum, quomodo id faciat. /

[40] Experio[r] et animaduerto, quod istae operationes fiant in me supernaturaliter etiam contra na- / turalem meam inclinationem; nam secundum 
From the divine heart comes a power, that flows from her to help the King of France, whom she declares to be truly converted. The spirit of prayer for him continues while she perceives that the divine majesty reassures her of the certainty of success.

When I was about 2 or 3 days in prayer, I saw some divine virtue and grace flowing from the divine heart ... which seemed ... to continue to flow to help the King of France.... say that the King of France is not truly converted, and that he encourages the Turks to attack the King ... of the Christians ${ }^{6}$, if indeed this were so, how then could Jesus love the King as truly as I see that ... Jesus loves him.

... November 1672 the spirit of prayer continues, as described above and immediately ... and more vivid, with the perception of the sweet divine majesty within me, that for me ... lures and guides me ... with very great confidence, faith and certainty about the good result.

This sweet majesty I see and carry constantly within me either in prayer or elsewhere. Nothing can prevent me from perceiving him: that I constantly contemplate him and lovingly cling to him and speak and talk to him confidentially and as between friends, for the spirit that is unbound and free from everything and from all other things can reside in the interior castle of the soul: ${ }^{7}$ as if he is separated from other things that are manifold ........... corporeal and sensual things, and not assumed but permitted by the spirit, for all the foretold ... of the spirit of love are founded and penetrated by the unity of God and so without ....... is one and the same spirit of God that brings about all these different effects.

Against the tendency of her nature she is moved by God to pray for the success of the King of France, with the assurance that God is favourable to him, and that he prevails. She considers the enemy armies as flies: with her spirit she surrounds the French army, the way the spirit does.

I experience and perceive that these effects occur in me supernaturally and even against my natural inclination, because by nature I am more inclined to

6 It is not clear to which contact of the French King with the Turks Maria refers here. But we have to see this in the light of the history of the struggle for power in Europe. In the ongoing fight between the Hapsburg and the Ottoman empire, France benefited from the opposition of the Turks against the Habsburgs and the Spaniards, who otherwise would have had too much power in Europe. This implicit support of the French though was contrary to the conflict of religions of the western Christian World against the Islamic World of the Ottomans. But all of this occurred mainly in the late sixteenth century (Lesaffer 1999, 21).

7 See the article of Elisabeth Hense, 253-265. 
naturam magis inclinor ad iuuandum Regem Hispaniarum, / ut desiderem et postulem prosperitatem in illius armis, quia ipse est noster Rex, et etiam Ca- / tholicus. //

[1] Ideo cogito, quod Deus decreuerit Regem Galliae honorare et eius regnum ampliare, et ideo me contra na- / turalem affectum faciat propendere, et stare pro parte huius Regis, ut eum iuuem. / Spiritus amoris et orationis pergit, uti supra dictum est, sed cum maiori tranquilitate, et intimitate Spiritus / etiam agitur, et certificatur, quod Deus se teneat pro parte Regis Galliae, et ideo ipse reportabit uictorias de ini- / [5] micis suis; de hoc non est dubitandum; hoc est certum et fixum; etiamsi exterior apparentia se aliter manifestet / utpote cum duo uel tres potentes exercitus ualidorum, robustorum, et in militia expertorum militum, sese illi opponunt, / nam si sunt in mente et animo meo uelut multitudo muscarum, sine uirtute, sine fortitudine, sine robore comparatiue / ad uirtutem et potentiam Dei, qui se inclinat, et beneuolum exhibet erga exercitum Regis Galliae. / Spiritus sese dispergit et expandit super hunc exercitum, illum quasi circumprehendendo: neque hoc in me operatur / [10] meus humanus Spiritus, sed est Spiritus Dei meo Spiritui unitus, qui id in me et per me et mecum operatur; / hoc fit tempore tranquillissimae quietis, et intimae coniunctionis, seu unionis mei spiritus cum diuino, sine uerbis / sine cogitationibus, et fere sine aliqua imaginatione alicuius rei corporeae. / Haec dispositio est nimis nobilis et nimis intima quam ut admittat, uel compatiatur aliquam imaginariam seu / corpoream imaginationem seu speciem alicuius rei in Deo cognitae aut memoratae ut summum sunt imaginationes / [15] seu species intellectuales (ut mihi uidetur) quae ibi tolerantur; quod si quidpiam, quantum ac ubique parum / de meo ibi uellem intermiscere, spiritus illico totaliter euanesceret, et obnubilaretur, ac redirem in meam naturam. / 
help the King of Spain, ${ }^{8}$ so as to desire and demand the prosperity of his arms, because he is our King and he is catholic. ${ }^{9}$

311

I therefore believe that God has decided to honour the King of France and to expand his empire, and therefore he makes me incline against my natural feeling and stand on the side of this King, to help him. The spirit of love and prayer continues, as stated above, but with greater tranquillity and in the intimacy of the Spirit it is even said and assured that God is on the side of the King of France and that therefore he will bring back the victory over his enemies. There is no doubt about this, it is for sure, even if appearances might suggest otherwise, as it is when two or three strong armies of mighty and solid soldiers experienced in war would oppose him, because in my mind and in my heart they are like a swarm of flies ${ }^{10}$, without courage, without strength or power that might be compared with the strength and power of God, who inclines towards and shows kindness to the army of the King of France. The spirit spreads and extends itself over the army, as if going around it, and my human spirit is not doing this in me, but it is the Spirit of God united with my spirit that works in me and through me and with me. This happens at a time of very great quiet and calm, of intimate connection or union of my spirit with the divine, without words, without thoughts, and almost without any imagination of any corporeal thing. This disposition is too noble and too intimate to allow or tolerate any imaginative or physical representation of the image of a thing known or remembered in God, as if intellectual visions or images (as seems to me) are the highest, ${ }^{11}$ which are tolerated there, but if I would intermingle myself in it, no matter how much and no matter where, the spirit would immediately and completely evaporate and would be obscured and I would return to my nature.

8 I.e. King Charles II.

9 She should by nature be more inclined to the Spanish King, for the King of Spain is also the King of the Southern Netherlands, where she lives, which is still part of the Spanish kingdom.

This comparison with flies also occurs in Maria's letters. There she speaks about infernal spirits and compares them with flies. This image is known from Dutch spiritual tradition (see e.g. Lutgarde of Aywiers) and is used to indicate she has no fear of them, for flies can easily be beaten to death. In her trust in God there is nothing that can intimidate her. Even though these hostile armies are strong and powerful in this world, against the power of God they are nothing.

See the article of Elisabeth Hense, 253-265. 
Nihil aliud debeo facere quam manere in unione cum diuino spiritu, et pati diuinam istam in operationem; est / etiam idem spiritus, qui orat modo inenarrabili, prout ab aliquot mensibus: quando autem haec tam manifeste / in me percipio et experior, non habeo rationem, cur non exspectem uictoriosum successum et bonum exitum in fa- / [20] uorem Gallorum; cum neque malignus spiritus, nec natura talia possit operari, hoc bene scio. /

Magis confirmatur de uictorioso successu quam diu manet unio animae / cum Deo; et contra contrariam apparentiam iterum certificatur de / uictoria Gallorum. /

Die 12 dicti mensis continuatur in me certitudo ut ante, cum noua continu e et illumina- / [25] tione. Quando spiritus decrescit in puritate et flacessit in actuali dilectione et inim......... dilectum / conuersione; tunc etiam euanescit istud lumen, ista certitudo, et spiritus orandi et timore / quod omnes hae[c] praeuisiones deuenient in nihilum et abibunt in fumum; quod quadam uoc.....................debam / et timebam, quia erat mihi relatum de magna potentia et potentissimis exercitibus ibus con- / gregabantur, ut unanimiter aggrederentur et obruerent Regem Galliae; inde diceba...............extra omnem spem / [30] quod ipse posset euadere et in conflictu uictoriam reportare. /

Postquam meam uoluntatem conformassem, et uniuissem uoluntati dilecti mei, ut cum equanimitate et gaudio / spiritus hanc humiliationem sustinerem; subito reuertebatur spiritus et confirmabat omnes praedictas cert. [Sceneo] et spiritus non poterit cohibere, quia interius clamaret uictoria Gallis, uicto......... / quod spiritus plus uel minus est in Deo, proportionaliter etiam est maior uel minor conue.

[35] Quando eius spiritus est unitus Deo tunc est maio. / intellectus unitus intellectui diuino uidet sicut / uoluntas est una cum diuina unde etiam uult.

Quando spiritus humanus est unitus cum Deo, seu cum spiritu diuino tunc re............. / millum est lumen nec illuminatio quae mihi praebeat lumen, aut cognitionem........... / [40] humanus unitus intellectui diuino intelligit, cognoscit, uidet et scit ist.................... / praeuidet, et scit; quia tunc anima est unum cum Deo, et consequenter int................... / cum diuino uoluntas humana est tunc perfecte unita seu......um cum diuin 
I ought to do nothing but to remain in union with the divine spirit and to endure that divine operation. It is even the same spirit that is praying in an indescribable way, for so many months now, but when I perceive and experience these things so clearly in me, I have no reason, not to expect the winning success and the good result in favour of the French, for neither a bad spirit nor such a nature could bring about this, which I know very well.

She is more certain about the winning success as long as she stays in the union of her soul with God, and contrary to appearances she is again assured of the victory of the French.

On the 12th day of that month ${ }^{12}$, the certainty in me continues as before, with new ... and illumination. When the spirit decreases in purity and fades in active love and ... the Beloved by conversion. Then even the light, that certainty will fade and the spirit of prayer ... and by fear that all these visions would come to nothing and go up in smoke, what I by some ... and feared, because as I was told about the great power and powerful armies ${ }^{13}$... that were gathered to attack the King of France unanimously and overpower him, so I said ... beyond all hope that he might escape and carry the victory in the conflict.

After I had conformed my own will in oneness with the will of my Beloved, so as to endure this humiliation with equanimity and joy of spirit, suddenly the spirit returned and confirmed all that was said before ... and the spirit will not be able to restrain it, because from within the victory of the French cried out ... because the spirit is more or less in God, it is also proportionally greater or less ...

When her spirit is united with God, then ... is greater ... her intellect united with the divine intellect sees like ... the will is one with the divine and therefore also wants ...

When the human mind is united with God, or with the divine spirit, then ... there is no light nor illumination, which gives me the light or the knowledge ... the human ... united with the divine intellect understands, recognizes, sees and knows those ... foresees and knows. Because then the soul is one with God, and as a result ... with the divine ... the human will is then perfectly united or

\footnotetext{
12 I.e. November 1672.

13 In September 1672 the Elector of Brandenburg and the German Emperor raised a relief army of 6o,0oo soldiers in Halberstadt.
} 
Ideo uoluntas cum omnibus animae affectibus eo pro[uenue .et.] inclinatur.............. / et amplectatur, nam anima tunc est aliter maneri ..[0........ pelli...ad............]//

[1] nec minus quam Deus illa <sc. anima > desiderat uel uult: ad quaecumque Deus se conuertit ad ea etiam anima debet se / conuertere; quod Deus diligit, id etiam ipsa diligit, a quo Deus se auertit, ab eo etiam ipsa se auertit, nec / potest aliter, eo quod Deus eam possideat, moueat, regat, et cum ipsa sit unitus, ubi ipsa est unum esse, unum ope- / rari, et unum intelligere, unum uelle cum Deo. /

[5] Agitur diuersis modis orandi pro aliis, per instantias, per urgentem dilec- / tionem per sponsalem fiduciam ante faciem Dei, aliquando est apud Dilectum / in qualitate Reginae, quasi aequalis auctoritatis, et mittit Archangelum / Michaelem cum suis in adiutorium Gallorum. /

[10] Diuersi mihi adueniunt modi orandi, pro ut antehac; subinde cum instantia intima in spiritu, subinde cum urgente et efficaci amore, subinde cum sponsali amorosa confidentia. / Et familiaritate, quia haec uidetur animae intus dari; aliquando est quaedam profundior introtractio in spiritu / [ubi] spiritus est quasi ante faciem Dei, orans instanter cum amorosa instantia, sed nonformando aliqua uerba, ut cogi- / tationes. Haec oratio fit in spiritu per spiritum, absque cooperatione aliquarum aliarum potentiarum; haec oratio / facile duraret ad horas sine fatigatione; nam secundum omnem perceptibilitatem, est ipse ..et spirititus Dei qui / [15] orat in me et per me. /

Non debet Reuerentiae Vestrae uideri mirum quod dicam spiritum stare ante faciem Dei; placeat scire quod interiora mea / sint quasi caelum, in quo deus regnat, et perceptibiliter ac deprehensibiliter habet suam mansionem; tam certo / ac si ipsum oculis meis corporalibus uiderem, quamquam ego hoc caelum (quod in praesenti, et adhuc aliquando / [arias] sese manifestat cum 
... with the divine ... Therefore the will with all the emotions of the soul ... is inclined ... and is embraced, for the soul then ... is otherwise to stay ... ... $^{14}$

$31 \mathrm{~V}$

and the soul does not want or desire anything less than God: to whatever God turns, to that also my soul ought to turn. Whatever God loves, the soul also has to love that, from whatever God turns away, from that also the soul turns away, nor can the soul act in any other way, because God possesses it, moves it, leads it and is united with it, where it is one being, one working, one understanding and one willing with God.

She is driven by diverse ways of praying for others, with intercessions, with urgent love, with the Bride's confidence before the countenance of God. Sometimes she is with the Beloved in the quality of a Queen, as with an equal authority, and sends the Archangel Michael with his men to the aid of the French.

Diverse ways of praying came to me as before: now with an intimate intercession in the spirit, then with urgent and strong love, then with the loving confidentiality of a bride, because these seem to be given to the soul from within. Sometimes it is somehow drawn more deeply into ... the spirit is like as if it was before the countenance of God, praying earnestly with loving intercession, but not forming any words like thoughts. This prayer comes up in the spirit, by the spirit, without the cooperation of any other powers. ${ }^{15}$ This prayer easily lasts for hours without tiring, because according to all perception it is ... self and the spirit of God, who prays in me and through me.

To your Reverence it must not look strange that I say that my spirit stands before the countenance of God. It may please you to know that my inner self is like heaven, in which God reigns, and perceptibly and understandably has his dwelling, as certain as if I had seen him with my eyes, although I obscure this heaven (which in the present and again at other times will manifest itself with

14 Here the manuscript is at many places unreadable.

15 Maria Petyt speaks about higher and lower powers: potentiae superiores et inferiores. The lower powers are the sensory and emotional powers, and partly also the imaginary powers. The higher powers are spiritual powers of the human soul: intellect, will and memory. 
tam diuina claritate et gloria, ut id uerbis explicare nequem ) saepius per rem / [20] rudem actiuitatem, et alias imperfectiones obnubilem. /

Ibi uidet spiritus Deum Dilectum suum quasi facie ad faciem, ibi cum meo loquitur quasi ore ad os, corde ad / cor, ubi permittitur quasi quiescere et fugere ad cor Dei aliquid diuinum, quod anima non potest explicare / Aliquando spiritus est ante hanc diuinam faciem instar ignitae et ardentis scintillae tranquille et efficaciter / [eualdes] ead.....[a]more Dei. /

[25] Aliquando [anima] ... se sentit apud Dilectum suum plusquam in qualitate sponsae, sed etiam in qualitate Reginae / quasi constituta ....... [uslatus] in honoroficentia, aequali potestate, et auctoritate iuxta ipsum u.g. dum / rogans [Doler] b.... quatenus illi placeret mittere Sanctum Archangelum Michaëlem ad exercitum Francorum / et ipsu....... e quasi generalem istius exercitus cum multitudine ad huc aliorum Angelorum simul / cum ipso ..........andum exercitum aduersarius uidebatur mihi interius respondere tantum debes mandare / [30] ut regina su..... tis........ /

Intelligit quanti referat Gallos habere uictoriam in <imminenti> conflictu / in Charleroii, et quomodo Hollandi intendant Hispanos decipere / tur ad orandum ut Belgeum cedat Gallis. /

....tellexi in spiritu quanti sit momenti quod Rex Galliae imminentem conflictum lucretur atque ita / [35] ....................... [uinoiis ] sine iurisdictioni subicere; eo quod ubi mihi significatis ...eo.... / ...................a promotio S.tae Romanae num li et multi illud $\mathrm{s}$ / pro ....plausibilia et Bona [promessa] quae status Hollandiae uidentur facere / ............................ ...... atet ibi deceptio et dolus sub istis pro missis; nempe statum ac praeualuerint / .tatum recuperanierint se subtrasent Hispanis et cum his prouinciis facient / [40] egent, sine subiectione uel dependentia ab Hispanis nullis supremum dominum / ud se regiones multo magis intecientur Haeresibus et libertae Religionis / .....................um certa quod fuerat aliqua illuminatio supernaturalis sicut superior, sed / acta ex ratione et externa apparentia. / ditur cor meum nouo igne et relo ad orandum Deum ut potius ..a cum Hollandia / [45]

[1] Iterum agitur spiritu orandi pro Rege Galliae in spiritu per spiritum passiue se / habendo Deo per se orante per efficaces instantias. / 
divine clarity and glory, as I cannot explain in words), more often by some rude activity and other imperfections.

There the spirit sees his Beloved God as it were face to face, there he speaks as it were with my mouth to His mouth, with my heart to His heart, there he is allowed as it were to rest and take refuge within the heart of God, something divine which the soul cannot explain. Sometimes the spirit is before this divine countenance like a burning and fiery flame calmly and effectively ... love of God.

Sometimes the soul feels with the Beloved more in the quality of a Bride, but also in the quality of a Queen, as determined ... to honour, with equal power and authority with him e.g. while asking ... that it would please him that I would send the holy Archangel Michael to the French army ... and him ... as a general of that army with the multitude of other angels together with him ... the army seemed to answer contrary ...

She understands of how much importance it is that the French will have the victory in the imminent conflict in Charleroi, ${ }^{16}$ and how the Dutch ${ }^{17}$ intend to deceive the Spaniards ... to the praying that Belgium yields to the French.

$\ldots^{18}$

$32 \mathbf{r}$

Again she is driven by the spirit of praying for the French King, in the spirit, through the spirit, resting passively while God prayed through her with effective intercessions.

16 This is about the attack of the Dutch army supported by the Spaniards on the power base of the French in Charleroi which took place in December 1672. This power base was an important strategic location of the French, which they wanted to keep at all costs so as to preserve the connection with France. The French succeeded in retaining Charleroi. On December 22 the siege of the Dutch was lifted, but the French were not capable of getting hold of Belgium. They had to keep defending against the attacks of the Dutch Prince. See Rooms, 2007, 46ff.

17 By "the Dutch" we refer to the people from the Northern Netherlands.

18 In the manuscript here about ten lines are following, which are not transcribed, because they were too difficult to read and interpret. 
Die 14 Nouembris 1672. circa uesperas mihi iterum concedebatur spiritus orandi pro Rege Galliae, / sicut ante, n. ita ut oratio fieret in spiritu per spiritum, id est non per meam propriam actiuitatem, uel / [5] cooperationem, sed quam Deus operatur in fundo animae, anima se passiue habente; ista oratio fit ualde / uiuaciter, efficaciter, et incessanter, et tamen ualde tranquille, simpliciter, et intime (quantum / potui meminisse). Haec oratio fluebat ualde nobiliter et uigorose ex Deo, uelut ex suo scaturigine, seu / origine, et iterum refluebat in Deum, uelut ad suum finem cum eadem tranquillitate, pace, intimitate / et sine imaginatione alicuius rei corporeae, sine formatione uerborum aut sensus, nihil aliud distincte / [10] percipiendo nisi Deum, quem aspectebam et diligebam ardenti animo, et cum ardentibus desideriis exauditi- / onis; qui ardens animus, et feruentia desideria stabant quasi aperta ante Deum cum efficaci et feruen- / ti instantia, continua quasi fluendo in Deum modo informi et intimo, quem aliter uerbis explicare / non possum. /

Dico quod Deum et alias inoperationes illas distincte perciperem et alio sensu id fiebat indistincte et abs- / [15] que intellectuali comprehensione, prae intimitate, abstractione imaginum seu formarum, et sine / absorptione, in qua spiritus stabat, et erat introsumptus. /

Eius spiritus subinde quasi expansus ante faciem Dei cum magna reue- / rentia aperit desideria coram Deo quasi urgens cor Dei ut exaudiatur. /

Aliquando erat spiritus quasi extreme expansus seu extensus ante diuinam faciem cum magna / [20] uiuacitate amoris et reuerentia desideria animae stant quasi aperta coram Deo cum urgenti / et amabili applicatione appressione ad cor Dei, ut exaudiatur iuxta beneplacitum Dei quod agnoscit / esse situm in exaudiri in illis, quae per desideria modo silentioso propon..ntur; percipit ....... , quod Deus / in his suis potentiis taliter operetur, et haec desideria ab ipso proueniant, et his ........ntur, ut / ipsa diuino hoc modo Deum orat per Deum. /

[25] Intelligit etiam, sicut antehac quod Deus illa non intenderit dare nisi sic rogat<us $>$...co...cidetur / ipse mittere spiritum suum in nos, ut oremus, et postulemus gemitibus inenarrabil $<$ ibus $>$ |

Spiritus ita expansus ante faciem Dei habet diuersas <inoperationes> cogni- / tionis et amoris sine communicatione cum parte ....iore subinde / uidetur ibi liquefieri etc. occulto tamen modo efficiatur. orat. / 
On November the 14th 1672 about the time of Vespers again the spirit of praying for the French King was granted to me as before, for the prayer happened in the spirit through the spirit, which means not by my own activity of cooperation, but as if God works in the soil of my soul while the soul holds still. This prayer occurs very vividly, effectively and incessantly and yet quietly, simply and intimately (as far as I could remember). This prayer flowed very nobly and vigorously from God, like from his spring water, or origin, and flowed back to God, like to his goal with the same tranquillity, peace and intimacy and without the imagination of any other corporeal thing, without forming words or sentences, distinguishing nothing but God, to whom I looked up and loved with a burning mind and with burning desires of being heard. This burning mind and these fiery desires stood as it were open before God with an effective and burning intercession, continuously as it were flowing to God in a unformed and intimate way, which I cannot explain otherwise with words.

I say, that I perceived God and those others operations distinctly and this happened indistinctly with another sense and without intellectual understanding, rather with intimacy, abstraction from images and forms, and without absorption, in which the spirit stood and was taken in.

Her spirit as it were stretched out before the countenance of God and with great reverence expresses her desires before God as if to urge the heart of God to hear her.

Sometimes the spirit was as it were extremely stretched out or extended before the divine countenance, and with a great vivacity of love and reverential desires of the soul stood as it were open in front of God with an urgent and loving affection urging the heart of God, so as to be heard according to God's will, that she acknowledges to be found in being heard in these things, that are proposed by the desires in a silent way. I $\mathrm{t}^{19}$ understands ..., that God in his powers operates in such manner and that its desires come from Him and by these ... are ..., so that in this divine way she prays to God through God.

She understands as well, as before, that God has not intended giving unless he is asked, ... to send his spirit to us, so that we might pray and ask with indescribable sighs.

The spirit that is thus stretched out before the countenance of God, has diverse operations of thought and love without communication with the .... part, immediately afterwards she seemed to melt there etc. In a way that is hidden, she prays. 
[30] Quando spiritus interius ante faciem Dei stat quasi apertus et expansus, tam habet diuersas operati- / ones cognitionis et dilectionis, quibus se in Deo et per Deum occupat subinde cum [feruente] et off..... / te amore qui solummodo operatur scintillat, et fluit in potentiis superioribus et ....[rsiti] / ista inoperatio non d..stendit ... profunde, ut potentiae inferiores cum illa habeant..... / cationem nisi quasi de longi parte possent aliquid inuestigare quid fiat et tra....... / [35] in quadam aurora. /

Aliquando uidetur spiritus ante faciem diuinam quasi liquefieri euanes....... / se ipso; subinde uidetur se dimittere in aliquod profundum quasi in aliquo[d]........... / essentialis nihileitatis et indignitatis, quasi indignus apparere cord...... / orationes impendi et eo audiri. /

[40] Tali modo, in hac dimissione et muto silentio, spiritus se expandit uel....... / coram facie diuina, quasi non ausus stare ante illam et illam.......... / nostro modo loquendi prae magna reuerentia ueritus illum intuerit .......... //

[1] ..... tan .... Occulto quodam modo, quem $<$ non po $>$ ssum exprimere, quomodo spiritus adhuc facit instan- / tias et orat. uerbi gratia pro prosperitate istius Regis, pro conuersione haereticorum ad ueram fidem etc. Atque / haec omnia operatur spiritus per se ipsum, per influxus supernaturales et illuminationes a diuino spi- / ritu actus et directus, quae mihi nunc praeter exspectationem, fluide in mentem ueniunt, uti supra/ [5] cooperante Dilecto, ut Reuerentia Vestra melius ad omnia possit attendere et apprehendere discretiones spi- / rituum /

Agitur spiritu amoris erga Iesum ut sponsum et confidenter ac zelose / agit pro conuersione Hollandiae, ut constituta illius mater; et / renouatur in ea maternus affectus erga Hollandos conuertendos /

[10] Die 15. dicti mensis Nouembris 1672. post meridiem incipiebat spiritus amoris operari ualde suauiter / et affectuose erga Iesum Dilectum meum et erga Regem Galliae eiusque subditos, primo erga Iesum Dilectum / meum 
When the spirit internally stands before the countenance of God, as it were open and stretched out, still it has diverse operations of thought and love, with which it occupies itself in God and through God. Then with fervent and ... love, working only in one way, sparkles and flows in the higher powers and ... this operation doesn't descend ... deeply, so that the lower powers with that ... have ... unless as it were they could from a distant part trace something that happens and ... at some daybreak.

Sometimes the spirit seems as it were to melt before the divine countenance ... itself. Then it seems to let itself slip away in some profound place as it were in some ... of an essential nothingness and unworthiness, as to appear unworthy ... of prayers being dedicated and heard by Him.

Thus, in this dedication and mute silence, the spirit reaches out or ... before the divine countenance, as if not daring to stand before that countenance and that ... in our way of speaking, because of a great reverence, fearing to look up at $\operatorname{Him} . .$.

.$^{20}$

$32 \mathrm{v}$

... some hidden way, that I cannot express, how the spirit yet makes intercessions and prays, e.g. for the prosperity of that King, for the conversion of the heretics to the true faith etc. And the spirit operates all these things by itself through supernatural influences and illuminations given and driven by the divine spirit, that now above all expectations come to my mind like before, cooperating with the Beloved, so that Your Reverence might better apply and employ the discernment of the spirits to all of this. ${ }^{21}$

She is guided by the spirit of love towards Jesus and confidentially and zealously she acts for the conversion of Holland, as if she were its mother. And in her a motherly feeling is renewed for the conversion of the Dutch.

On the 15th of November 1672 in the afternoon the spirit of love began to work very pleasantly and tenderly towards Jesus my Beloved and towards the King of France and his subjects, first towards Jesus my Beloved as if I were his chosen

\footnotetext{
20 Here a part of the translation is omitted, because the original text (lines 34-45) is too badly damaged, and translation of the few words left would not add to the understanding of the text.

21 See the article of Veronie Meeuwsen, 240-251 and Anne-Marie Bos, 266-281.
} 
uelut electa et carissima eius sponsa cum confidentia, sic cum illo agendi; multis colloquiis Ze- / losi et Zelotypi, dementati et quasi insanientis amoris de promouendo eius honore et gloria per conuer- / siones animarum in Hollandia, cum renouatione memoriae, quod Dilectus me antehac fecerit quasi illius / [15] matrem; per quod in me renouabatur maternum cor; et maternus amor erga illos sicut antehac. /

Multa sic occurrebant postulanda a Dilecto meo ad eorum salutem procurandam et assecurandam / etiam erga milites Gallos; hi omnes erant adeo suaues et amabiles in mea mente et animo, quasi / omnes fuissent mei gemini filioli, et ego naturalis eorum mater; ideo sentiebam in me tenerrimam / cum ipsis compassionem quasi ipsamet sensissem eorum incommoda, frigus, penuriam etc. sicut natura[lis mater / [20] sentit] ..se compati et sentire incommoda dolores et inediam etc. naturalium filiorum. / ...................multae amorosae querimoniae ad Dilectum, quod hi mei filii istas omnes incommoditates / ............ $<$ in $>$ iurias ......suras infirmitates etc. sustinerent amore ipsius, ut eum iuuarent et con- / .............. regno, quos propterea deberet confortare refocillare, et calefacere interna di- $/$....lla .to. 1

[25] Redit in ipsa confidentia, et animus quasi Reginae, et ut talis agit / cum Dilecto et Angelis; et quod Traiectum / non capietur; postea cessat spiritus orandi et materne agendi. /

Adueni<unt $>$.......... quaedam confidentia et animus quasi Reginae in[uad]antis, adhuc efficace et uiu[ace] / qua.. ab aliquot cum tali animo plane confidenter ag[eb]am cum meo dilecto, et cum sanctis Angelis quasi / [30] iterum illis mandando, ut [unum] regnum Dilecti mei in Hollandia bene conseruarent et protegerent, ac generose / .....entur contra quoscumque qui Dilectum ibidem ex suo throno tentarent extrudere et ex suo regno expel- / ..Deu..... infernales iterum ibi ponerent in possesione uel saltem permitterent, ut Satan ibi haberet / ..................siones iuxta Dilectum per tolerantiam seu permissionem liber[ae] religionis Catholicae ad... / ...............intendunt) quam iniuriam Dilecto meo irrogari non possum pati. / [35] ................i et habere certitudinem, quod Dilectus impios qui inde ipsum exturbare inte- $/$ geret per uictoriosum conflictum Gallorum et alios qui irent in [Prosidium] Hollan- / ntionem, quod Rex Franciae lucraretur conflictum, et quod ciuitas Traiectensis / . bant ab illis non interciperentur. /

[40] e spiritus amoris et etiam spiritus orandi, nec mihi erat amplius poss[ine]/ .riore dispositionem animi, per quod mihi incederat, quod [forte] / ..............eram amplius orare uel exercere officia animi materni // 
and most beloved bride full of confidence, to act with Him in this way, in many conversations of a zealous, jealous, foolish and almost insane love, to promote his honour and glory by the conversion of the souls in Holland, with the renewal of the memory, that the Beloved already before had made me so to speak its mother. Through this, my motherly heart was renewed in me, and a motherly love towards them as before.

Many things occurred to me: that I had to ask my Beloved to take care of and secure salvation also with regard to the French soldiers. All of them were so pleasant and beloved to my mind and to my heart, as if they all were my little twin sons and I was their natural mother. Therefore I felt a very tender compassion for them, as if I myself felt their discomforts, their cold, their hardship etc., like a natural mother notices ... that she sympathises and feels the discomforts, pains and the lack of food etc. of her natural sons ... many loving complaints to the Beloved, that my sons endure all their discomforts ... injustices ... infirmities etc. out of love for Him, to help Him and ... his kingdom, whom she therefore has to comfort, refresh and warm with inner ...

In her the confidence returns as well as the heart of a Queen, and as such she speaks with the Beloved and the angels. She asks that Maastricht will not be captured ${ }^{22}$. Afterwards the spirit of praying and of motherly acting ceases.

Some kind of confidence and the heart of a Queen come to me, even more powerfully and vividly ... of so many ... with such a heart I spoke quite confidently with my Beloved and with the holy angels as if to ask them again to preserve and protect the kingdom of my Beloved in Holland and generously ... against all those who would try to remove the Beloved from his throne and expel Him from his kingdom ....

.$^{23}$

\footnotetext{
22 By reasons of chronology Trajectum is translated as Maastricht instead of Utrecht. From 7 November till 22 December 1672 William III marched from Roosendaal to Maastricht. He freed the city temporarily from the French troops, who had taken the city.

23 Lines 23-38 are omitted, because the manuscript has too many gaps here.
} 
[1] In intimitate spiritus habet impressiones, quod Dilectus [conqueratur] de / effusione sanguinis innocentis in Hollandia et de iniuria sibi facta / ab Hispanis, qui impediunt Regnum Iesu in Hollandia. /

Iam ab aliquot diebus fiebant in meo fundo aliquae subitae illuminationes et impressiones, modo / [5] alibi explicato ubi agebam de aliquibus subtilibus et rapidis scintillis fundo animae iniectis (nisi errem). / hae scintillae et impressiones uidebantur me illuminare et mihi ex parte Dilecti, notificare quomodo / ipse ualde conquereretur de innocente sanguine, qui iniuste ab utraque parte in Hollandia effunditur, / et de iniuria sibi irrogata ex parte Hispanorum, qui uidentur uelle impendere omnes suas uires, / extrema uti potentia ad Iesum expellendum ex suo nouo regno, et quantum est in se, conantur / [10] impedire pacificam possessionem desiderati regni illius et fidei Catholicae ibidem plantari caeptae etc. / Non quod Hispani habeant expressam illam intentionem; sed quia commodant arma sua Haereticis ad ex- / pellendum Regem Galliae, [nixi] aliquibus promissis ab impia illa natione sibi factis, et sub spe, quod / [ipsimet] Hollandiam paulatim occupabant, et tandem totaliter suae subiicient ditioni. /

Verum iuxta ea; quae ego tunc ulterius uidebam et intelligebam, ista spes uana est et nulla, absque u........ / [15] secuturo effectu. Intelligebam etiam quod promissa haereticorum et praesentationes ab illis Reginae facta...... / non subsistent, et sint plenae dolis, et deceptionibus. Aliquo tempore Regina habebit possessionem et <iurisdictionem> / in aliquot eorum ciuitatibus. Seu si Deus permittat (quod Deus auertat) ut Rex Galliae cladem accipiat / et succumbat, et acceptae ciuitates ui armorum ipsi eripiantur; ista possessio Hispanorum <numquam $>$ / durabit nec etiam unio quam Hollandi et Hispani habent inter se./

[20] Sed Haeretici a suis hostibus liberati et pristinis uiribus restituti, aliquos alios hostes............... / ut Hispanos et Religionem Catholicam exterminent: quo casu et tempore Rex Gal..... / Regina Hispaniarum etiam frustrabitur omni spe exspectatione et promissis sibi fact....... / O quantam iniuriam et praeiudicium inde patentur Iesus quam infinita mala et ................... / ...eni.ent .. qualem uindictam clamaret apud Deum innocens ille sanguis ex utraque po. allorum / [25] t..m c...e effusus! eo quod utrumque esset effusum sine fructu, de quibus ............... deberent / spon...ere apud Deum; quippe Rex Galliae usque modo effundit illum sanguinis ipso titulo ex zelo et inter- / ....e plantandi ibidem ueram et ortodoxam fidem et plantabam conseruan...... haec effusio sanguinis ex parte / Regis Galliae est sancta et iusta. / 
In the intimacy of the spirit she has impressions, that the Beloved complains of the effusion of innocent blood in Holland and of the injustice done to Him by the Spaniards, who try to prevent the kingdom of Jesus in Holland.

Already for so many days now some sudden illuminations and impressions occurred in my depths, in a way that I explained elsewhere when I spoke about some subtle and consuming sparks emerging from the bottom of my soul (if I'm not mistaken). These sparks and impressions seemed to enlighten me and to notify me from the side of the Beloved how He complained very much about the innocent blood, which is unjustly shed by both sides in Holland and about the injustice done to Him from the side of the Spaniards, who seemed to use all of their forces and an extreme power to expel Jesus from his new kingdom, and, as far as they could, they tried to prevent the peaceful possession of His desired kingdom and of the catholic faith that began to be planted there etc. Not that the Spaniards have expressed this intention, but because they supply the heretics with their arms in order to expel the King of France, trusting in some promises made to them by that impious nation, hoping that they themselves would occupy Holland, gradually and eventually would subject them to their power.

But because of those things, which I then saw and understood, this hope is vain and worth nothing, without ... the effect which will follow. I understood even that the promises of the heretics and the proposals made by them to the queen ${ }^{24}$ would not last and that they are full of tricks and deceptions. Some time the queen will have possession and jurisdiction in some of their cities. Or, if God would allow (which God forbid!) that the King of France is defeated and succumbs and that also the conquered cities are captured by force of arms, then this possession of the Spaniards would never last; neither would the unity that the Dutch and the Spaniards have between them.

But the heretics freed from their enemies and restored to their former powers, will unite with some other enemies in order to expel the Spaniards and the Catholic Religion, in which case and time the King of France ... the queen of the Spaniards will be also frustrated by all the hope, expectation and promises made to her ... ${ }^{25}$

24 Maria refers here to queen Mariana of Austria, the mother of Charles II.

25 Lines 20-35 are omitted, because the manuscript is too difficult to read there. 
Deum uae et uae illis, qui ex liuore ex inuidia et propria quaesitione compluerunt, et persuase... / [30] ........... lo me Regis istius propositum et intentum impediret ciuitates interceptas a ......... / aliquo sensu iterum [tradet] in [man]us haereticorum. / Etsi Galli praeualeant equidem Hispani [sunt] ......... / guinis effusi; nec eorum intentio ualet apud Deu....... / tasset praesentationem Regis Galliae. Holland....... / [35] Reges mansistent uniti. /

Et....... licet Dilectus per suam omnipotentem manum permitteret u........ / ..... num ..ominem temeret equidem Hispani magna ex parte............ / [apud sustanem] et in fructu[sla] effusio [omnis] istius innocentis sangui................ //

\section{$33 \mathbf{v}$}

[1] tionem et resistentiam isti Regi in laudabili et deiformi illo intento factam: neque eos apud Deum excusabit / putata ipsorum bona intentio quia destruunt certam Dei gratiam, et salutem tot millium animarum, quae cum / habet stabilitatem et locum propter incertam et propria quaesitione mixta[m] gloriam Dei a se praetensam ut exspec- / tatam, quae est fundata super arenam, uel in uento, quem uolunt apprehendere sed qui e manibus auolant / [5] ad magnum eorum paenitere postea quando erit serius. /

Utinam Consiliarii Reginae haberent oculum ad promouendam in Hollandia puram et nudam gloriam Dei, et / salutem animarum, nam sicut uidebar intelligere diuinum illud lumen improbabat et culpabat ipsorum / conceptus proposita et concordiam seu pactum initum cum Hollandis. /

Intellegebam etiam, quod Regina melius et satius fecisset pro se et Deo gratius, si praesentationes Regis / [10] Franciae acceptasset; sic regnum ipsius mansisset in parte, et plus profecisset, quam iam (ubique postmodum) / et rex cum modica effusione sanguinis prosperasset et progressus fuisset in Deiformi suo proposito et inten- / to; accedit quod sic inter Reges Catholicos mansisset maior unio, pax et concordia; ubi iam apparenter / inter eos exorietur capitale odium, dissentio et inimicitia in ruinam totius patriae /

Explicat., quales fuerint praedictae cognitiones, quae supernaturales, quae / [15] non; timet Hispanis; et haec scribit inuita. /

Non dico quod haec omnes fuerint cognitiones supernaturales; sed a tempore, quo mihi contigerunt / dictae impressiones etc. omnes praetactae cognitiones stabiliter manserunt impressae in fundo meo, et / quando spiritus in me operatur, renouantur illae iterum et confirmantur, ut uerae; et manent tam / ...uc et certo mihi insitae, ut non possim illas reiicere uel diffiteri. / [20] lectas 
$33 \mathbf{v}$

... and resistance committed against this King in his laudable and godly intention: and their putative good intention will not excuse them before God, because they destroy the certain grace of God and the salvation of so many souls, which now has stability and place, because of the glory of God which is to them uncertain and mixed with self-interest, presented by them as expected, which is founded on sand ${ }^{26}$, or in the wind, which they want to $\operatorname{catch}^{27}$ but which will fly away from their hands to their great regret later when it will be too late.

$\mathrm{O}$, if only the Counsellors of the queen had an eye to promote the pure and naked glory of God in Holland and the salvation of the souls, because as I seem to understand that divine light it rejects and disapproves of their concepts and plans, and their agreement or pact with the Dutch.

I understood as well that the queen would have acted better and satisfyingly to herself and more pleasingly to God, if she had accepted the proposals of the King of France. In that way she would have kept her kingdom and would have profited more than now (a little bit later) and the King would have brought about a good end with moderate spilling of blood and he would have been progressed in his godlike proposal and intention. Also there would have been a greater unity, peace and concord between the catholic Kings, while now apparently between them a profound hatred, discord and enmity is emerging, which ruins the entire land.

She explains of what kind the aforementioned thoughts were, which were supernatural and which were not. She fears the Spaniards and writes about this unwillingly.

I do not say that all these thoughts were supernatural, but from the time, that these impressions came to me, all thoughts that I obtained before stayed firmly impressed deep within me, and when the spirit worked in me, then they were renewed and confirmed as being true. And they remain so ... and certainly rooted in me, so that I could not reject or deny them.

She returns ${ }^{28}$

26 Cf. Mt. 7,26-27.

27 Cf. Prov. 30,4; Eccl. 1,14.

28 At the bottom of this page is written the custode (catchword) Redit. This is an indication that the next page should begin with this word Redit. But the next page in the manuscript 
mihi [faciet ut] illas querelas de iniuriis ab Hispanis sibi illatis, et de ista effusione / ......inis innocentis cuius Hispani sunt causa; secundum omnem apparentiam et quantum/ illuminatio supernaturalis in magna tranquilitate et abstractione sine / ..one potentiarum inferiorum; id fiebat celeriter et uelociter, sed cum plena / .......titudo ......ntione ueritatis; et ista certitudo ab illo tempore sic mansit aliquando cum / [25] ......aliquo..........itudine amoris propter iniuriam quae Dilecto meo et multis animabus / ........rogatur. /

......u ..b[is] intimae illae que....iae Dilecti aliquid portendunt, et ad illas bene attendere oportet / ...............nde [aff]ectus p.............os; nam si haec sint uera, non tam suauiter trans[ibunt] / .......nius, sine post aliquod te ....... pro certo Dilectus ista non permittet sic transire, quia / [30] ........[ennis], magnum isi forte in meis illuminationibus decipiar; quod / .............uodem non potui.. me cohibere, quem haec annotarim, postquam saepius / .......... f f.... in abundantia inter scribendum cum tali pondere et sertim / haeream consternata. Tempus docebit, a quo spiritus / .................... mihi quod auaritia fefellerit sapientiam Hispaniorum. /

[35] Redit //

[1] Die 4 Julii intellexi, ciuitatem Traiectensem Regi Galliae traditum eodem / die quo mihi significabatur, Regem accepisse auxiliam et assistentiam a sanctis / Angelis, n. die 3 o Junii; sit inde Deus benedictus in saecula. /

Patitur quasi infernale tormentum pro peccatis Regis Galliae, quod/ [5] tormentum utcumque describit, et diu patitur sine solatio. /

Usque ad octauam Julii, Dilectus secundum omnem apparentiam, me usus est, ut satis- / facerem pro delictis Regis Galliae, accepta mea praesentatione ad satisfaciendum / pro illo, et patiendas etiam paenas infernales; quod certo quodam modo mihi fuit / concessum per insolitum, et a me hactenus non probatum tormentum, quod debui / [10] sustinere in anima mea, et mihi uidebatur esse poena infernalis./ Mihi uidebatur, quod sub corde meo quasi accenderetur ignis, quo cor ineffabili / modo cruciabatur, et tormentabatur; praeterea omnia, quae per sensus, per auditum, / uisum, tactum, et gustum poterant intrare; Item per imaginationem, uel alias / potentias sensitiuas, ista omnia, ista abiecta uidebantur tendere ad cor, ad / [15] illud cruciandum modo ineffabili. / 
On the 4th of July ${ }^{29}$ I understood that the city of Maastricht was delivered to the King of France on the same day on which to me a sign was given that the King had accepted my help and assistance from the holy angels, namely on the 3oth of June..$^{30}$ May God be blessed therefore in eternity.

She suffers as it were infernal torment for the sins of the King of France, which she describes as well as she can, and she suffers for a long period of time without consolation.

After my proposal to make reparation for him and even to suffer infernal penances, the Beloved used me until the 8th of July, according to all appearances, to make reparation for the faults of the King of France. For sure that was something that was allowed to happen to me in some way by an unusual and by me not yet endured torment, which I had to undergo in my soul, and which seemed to me to be an infernal punishment. To me it seemed that under my heart as it were a fire was ignited, through which my heart was tortured and tormented. Besides all of this, there was all that came to me through the senses, through hearing, through vision, touch and taste. Also through imagination or other sensory powers, all these things, that I had rejected seemed to press upon my heart, to torture it in an ineffable manner.

begins with a different word. This is an important evidence that the manuscript has not been bound in the right sequence. The next page should be 42 r, which begins with the custode Redit, and which also connects to this page $33 \mathrm{v}$ chronologically. See footnote 1 about the original sequence of the manuscript.

29 Here begins the fourth part of the document. 4 July 1673 is intended. The Siege of Maastricht took place between 13 June and 26 June 1673 .

$30 \quad$ On 30 June the surrender of the city had taken place. 
Insuper omnes creaturae uidebantur insurgere contra me, quasi a Deo fuissent ad- / hibitae, uelut instrumenta ad me cruciandum; in omnibus rebus, et occurentiis, sen- / tiebam extremam contrarietatem, et repugnantiam; pars superior erat quasi - / cooperta, et sepulta in sensualitatibus naturae, et quasi submersa in mari amari- / [20] tudinis; aliquando prae uehementia paenarum, eram quasi extra me, et ualde ob- / tenebrata in intellectu, et de facto, prae nimia duratione patiebar quasi de- / liquia; quippe uires consumebantur per praemagnam illam et omnis solatii / expertem passionem in spiritu, et naturam. /

Postea subinde parum consolabar, et confortabar per aliquem suauem, inti- / [25] mum occursum et fruitionem praesentiae Dilecti mei, sed plerumque uersor in statibus / paenalibus, praesertim sentiendo naturales meas passiones, quae iterum quasi reuiriscunt / imo uidentur uiuaciores, quam umquam C praesertim prouitas ad subitandum Chole- / ram. Ac, quamuis enim per Dei gratiam passiones illas non sequar, equidem / illas sentire tam uiuas, est mihi magna crux. /

[30] Agitur uehementibus passionum motibus, quasi sibi relicta, et / tristis usque ad mortem etc tandem cessant penalitates, quas / partim pro Rege partim ad exercitium humilitatis sustinuit. /

Passiones, quas sentio, sunt quasi tortores, seu crudeles lictores, ad torquendam / animam, eo magis, quod debeam eas comprimere, et earum motibus incessanter resistere, / [35] et quia sentio aliqua apparentia mala, uel inuita, subinde timeo, ne sim in malo / [stratu], quippe istae sensibilitates, et passionum uiuacitates sunt ualde peregrinae, et / insolitae, inde nescio quid cogitare; an non sit ibi manifest<atio>..ignium defectionis / in uia perfectionis, quae mihi persuadebam me iam supra endisse, et per- / fectioni ualde appropinquare; aliquando uereor, ne alicu.....ittam aliquod / [40] magnum scandalum; inde quasi timeo a me ipsa, et mihi ipsi plane diffido. /

Passio tristitiae etiam non est minor, nec eam possum diuertere; anima mea / est quasi tota perfusa, et penetrata interno [maerore], tristitia, et pressura; uide< or $>$ / aliquo modo experiri tristitiam et pressuram, quam Jesus sustinuit in hortu/ quando dicebat, tristis est anima mea usque mortem: o quantopere qua....// 
Besides all creatures seemed to rise against me, as if they were used by God as instruments to torture me. In all these things and occurrences I felt an extreme contrariety and contradiction. My superior part was as it were covered up and buried in the sensations of nature, and as it were submersed in a sea of bitterness. Sometimes because of the violence of the punishments I was as it were outside myself and my intellect was darkened and in fact because of the long lasting duration I suffered like a criminal. For my powers were (strength was) consumed by that very great suffering in spirit and nature.

After that suddenly I was consoled somewhat and comforted by some pleasant intimate encounter and the joy of the presence of my Beloved. Mostly I remained in a harassing (distressing) state, feeling particularly my natural suffering, which comes back to life and even seems to become more vigorous than ever, especially making me feel as if I was about to contract Cholera. And although by God's grace I will not catch that disease, it still is a heavy cross for me to feel these things so in such a lifelike way.

She is seized by violent motions of suffering, as if she were left to herself, and saddened to death etc. Finally the punishments stop, punishments she had endured partly for the King and partly as an exercise of humility.

The passions that I am feeling are like the torture of a cruel flogging, to torment my soul, even more because I must suppress them and resist their motions incessantly. And because I experience some bad or unwanted appearances, I suddenly fear to be in a bad situation, for these sensations and the vividness of this suffering are very strange and unusual. Therefore I do not know what I should think: whether or not it is a manifest sign of weakening on the way to perfection, of which I had persuaded myself that I had already ... and truly approach perfection. Sometimes I fear, that some ... some great scandal. Therefore I am somewhat afraid of myself, and distrust myself completely.

The suffering of sadness is not less, and I cannot turn it away. My soul is as it were totally invaded and penetrated with inner sadness, sorrow and depression. I seem in some way to experience the sorrow and depression that Jesus endured in the garden, when he said: "my soul is saddened to death". ${ }^{31} \mathrm{O}$ how much ... 
[1] hi itatus! quam procul absum ab omni uana praesumptione! quidquid / umquam boni in me fuit, hic quasi euanescit, et est, quasi numquam fuisset; / etiam quae antecedenter scripta sunt de Rege Galliae, non possunt mihi seruire ad / aliquod solatium. /

[5] Die 11 dicti mensis totaliter cessauit passibilis illa et sensibilis dispositio; et / sentio me, sicut antea, plane suauem et mitem, a motibus passionum, et oppug- / nationibus partis inferioris plane liberam; et licet laboriose conarer, non / possem tales naturae sensibilitates causare; uidentur ista iam transacta / esse in alio homine; cum interna certificatione, quod istos paenales status / [10] sustinuerim ex speciali dispositione et permissione Dilecti, partim, ut satis- / facerem pro Rege Galliae, et partim, ut sic melius conseruarer humilitate. / Sic Dilectus nouit prudenter mecum agere; ne uane me extollam in / eius donis; ipse me ponit in meo nihilo, et me facit experiri meam impossibilitatem /

Post aliquam animi repugnantiam scribit ex obedientia aliqua / [15] de sua interiori dispositione; iussa orare contra Gallos in / Hollandia, agitur diuino spiritu orandi in illorum fauorem. /

Die 6. Januarii 1674, ad honorem et gloriam ssmae Trinitatis. quando qui- / dem Reuerentiae Vestrae desiderium sit, ut aliqua scribam, quae in me aguntur, faciam / quod potero, et scribam ea, quae mihi occurunt; sensi aliquam in hoc animi / [20] repugnantiam, sed iam me sentio suauius inclinatam, propter spem, quod/ per hoc inueniam aliquam occasionem humiliationis, eo quod per omnes / istas nugas, omnes aliae meae apparenter perfectiones, et inoperationes / spiritus, etiam parui fient, nec approbabuntur; haec spes me allicit et / exstimulat, ut omnes meas nugas resolute edicam. /

[25] Cum ad requisitionem suae Excellentiae, Gubernatoris Patriae, esset in- / dictus generalis dies precum in omnibus huius urbis Ecclesiis, n. in ipsa / uigilia natalitiorum, et primo ac secundo festo, ut attentatum contra Gallos / in Hollandia ad uotum succederet; conabar una cum aliis iungere preces / meas, et ad intentum orare. Sed spiritus meus non uolebat se conforma[re] / [30] nec 
... How far away am I from every vain presumption! Whatever good has ever been in me, that evaporates now as it were and it is as if it had never been there. Even what I have written before about the King of France, cannot serve me now as consolation. ${ }^{32}$

On the 11th of this month ${ }^{33}$ this suffering and sensitive state ceased in me totally. And I feel as before, completely pleasant and gentle, completely free from motions of suffering and attacks of my inferior part. And although I tried strenuously, I could not cause such sensitivities of nature. They seemed already to have transferred to another human being. With inner certainty that I had endured those tormenting states because of a special disposition and permission of the Beloved, partly to make reparation for the King of France, and partly so that I would be kept in greater humility. Thus the Beloved knew how to act prudently with me, so that I would not extol myself in his gifts in vain; he placed me in my nothingness, and made me experience my powerlessness.

After some repugnance in her heart she writes out of obedience some things about her inner state. Although she is commanded to pray against the French in Holland, she is driven by a divine spirit to pray in their favour.

On the 6th of January 1674 , to the honour and glory of the most holy Trinity. When Your Reverence wishes, that I write about some of the things that happen in me, I will do whatever I can and will write those things that occur to me. I have felt some repugnance of heart in this, but I already feel more pleasantly inclined, because of the hope that I will find in this some occasion of humility, because through all these trifles, all these apparent perfections of mine and the workings of the spirit, will also become little, and they will not be approved. This hope allures and stimulates me, to proclaim all my trifles resolutely.

When at the request of His Excellency, the Governor of the country ${ }^{34}$, a general day of prayer in Churches of this city ${ }^{35}$ was announced, to take place on Christmas eve, and on the first and second feast day, so that the attack against the French in Holland would succeed as desired, I tried to unite my prayers with the others and to pray according to his intention. But my spirit did not

\footnotetext{
32 N.B. This is the fourth part of the document. Maria refers here to following passages.

33 I.e. July 1673.

34 I.e. Don Juan Domingo Mendez de Haro, See also n. 78.

35 I.e. Mechelen.
} 
cooperari; furiebam interim secundum uoluntatem et spiritum humanum / quod poteram, ut obtemperarem mandato superiorum. /

Die 30 natalitiorum, n. in festo S. Joannis, uidebatur spiritus diuinus in / me orare, et postulare gemitibus inenarrabilibus, et in me operari modo insolito / et inexspectato, plane contrario requisitioni et intentioni nostri Principis; / [35] imprimis eram [in]trosumpta seu introtracta in illa extraordinaria et prae- / magna unione cum Diuinitate, quasi etiam ab uno aut altero anno fruita / fui; In hac unione, subinde per uires nonnihil demittebar cum aliquali / mei ipsius perceptione, non rudi, sed ualde sublimi, spirituali, et nobili modo / nempe in qualitate tenerrimae et amantissimae sponsae, quae permittitur, uel / [40] potius a diuino spiritu taliter agitur, ut cum suo diuino Dilecto confidenter / et familiariter conuersetur, et agat de rebus ipsum concernentibus: / non tamen //

\section{$35^{r}$}

[1] Non tamen uidebam Christi humanitatem, sed erat comprehensa, et abscon- / dita sub summo illo Bono, seu diuina Essentia, quae se mihi manifestabat; / et sui fruitionem indulgebat; nam nullae species imaginariae in me tole- / rabantur, sed solae intellectuales. /

[5] Tenerrimus ille sponsalis amor dabat mihi confidentiam postulandi et / orandi Dilectum meum, ut, cum ipsi notum esset, per quos eius honor et gloria, / deberet promoueri, et Bonum Sanctae Ecclesiae, ac salus animarum prosperari,/ et iuuari, siue per exercitum Caesarium, siue per exercitum Hispanorum, siue / per exercitum Gallorum, dignaretur benedicere illis, per quos maius / [10] bonum fieret; ac proinde, ut secundum diuinam suam prouidentiam, et / Charissimum beneplacitum uellet illis auxiliari, et dare uictoriam. /

Videbar percipere, quod Deus inclinaretur, et se conuerteret ad exercitum / Gallorum, et se ab illis auerteret; tali modo mihi insinuando, et spem dando, / quod daret suam benedictionem, et manus auxiliatrices Gallis, ut sic diuinae / [15] prouidentiae dispositio fortiretur effectum, non obstante, quod humanitus loquendo / id uideretur esse extra omnem apparentiam et econtra esset summa appa- / rentia, quod Galli succumberent, et ad internecionem redigerentur, propter / potentissimos exercitus Imperatoris et Regis Hispaniarum illos aggredi paratos. / 
want to conform and cooperate. I exerted myself in the meantime with all my will and human spirit, as far as I could, to obey the command of my superiors.

On the 3oth of December, on the feast of St. John, the divine spirit seemed to pray in me and to postulate with indescribable sighs and to operate in me in an unusual and unexpected way, clearly contrary to the request and the intention of our Prince. ${ }^{36}$ Firstly I was turned or drawn inward in that extraordinary and very great union with the Divinity, as I had enjoyed it for one year or another. In this union, suddenly I was somewhat brought down by forces with some perception of myself, not in a rude, but in a very sublime, spiritual and noble way, in the quality of a very tender and loving bride, who is permitted or better who is so by the divine spirit, that she associates with her divine Beloved confidently and familiarly, and speaks about things that concern Him:

Yet I did not see the humanity of Christ, but that was enclosed and hidden under that highest Good, or the divine Essence, that manifested itself to me and that allowed me to enjoy it. For no image was tolerated in me, but only intellectual images.

That very tender bridal love gave me the confidence to ask and pray to my Beloved, that - while it was known to Him, by whom his honour and glory should be promoted and the salvation of souls should be advanced and helped, whether by the army of the Emperor ${ }^{37}$ or by the army of the Spaniards or by the army of the French - that he should bless them, by whom a greater good could happen and then, according to his divine providence and his most beloved will, that he would help them and grant them victory.

I seemed to perceive that God inclined towards and turned to the army of the French, and that He turned away from the others. In this way suggesting to me and giving me hope that He would give his blessing and a helpful hand to the French, so that in this way the disposition of divine providence would strengthen the effect, notwithstanding that humanly speaking this seemed to be beyond all appearance and that to the contrary it was the most likely outcome that the French would succumb and would be destroyed because of the most powerful armies of the Emperor and of the King of the Spaniards that were ready to attack them.

${ }_{36}$ Perhaps she refers here to Don John of Austria, natural son of Philip IV. In 1672 he still was titular Governor of the Southern Netherlands.

37 I.e Leopold I. 
Porro Dilectus uidebatur a me requirere, ut Gallis impertirer eius / [20] benedictionem; quod sic ipso facto faciebam, et videbar aliquo modo imprecari / maledictionem nostro exercitui, nimirum nostris subtrahendo omnem sapientiam, / animos, et uirtutem; id non faciebam ex me ipsa, sed diuinus spiritus uide- / batur id in me, et per me operari, absque eo, quod id possem impedire. /

Familiariter agit cum Angelis pro auxilio Gallorum, intellectus / [25] unitur intellectui diuino, cum assecuratione diuinae inoperationis pro Gallis. /

Isto tempore etiam agebam ualde familiariter cum sanctis Angelis, uelut / cum administratoriis spiritibus Dilecti mei, ipsis committendo omnem curam/ conuersandi, amplificandi, et stabiliendi regnum Dilecti mei, et in istum / finem, personaliter accedendi, et in congressibus auxiliandi illis, quos Dilectus / [30] ad hoc elegerat: id fiebat cum tanta fiducia, fide et animi libertate, ut / de ueritate illorum ne uel semel possim dubitare. /

Post quam familiarem cum Angelis conuersationem [e]t communicationem / continuo introsumebar et introtrahebar in praedicta ....ni...ente unione, / non solum in unione mei spiritus cum spiritu Dei, s[ed] ....... Unione / [35] potentiarum superiorum, nempe intellectus cum intellectu diuino, memoriae / cum memoria diuina, uoluntatis cum uoluntate diuina, hoc est aliquid / aliud, quam quod ordinarie nominatur uel dicitur unio cum Deo; ad hanc / unionem explicandam, multa occurerent dicenda, quae tempus iam non permitt.... / Eodem tempore iterum plene certificabar quod omnes illae inoperatio[nes] //

[1] illuminationes, et modi orandi spiritus etc quae a duobus annis in me / fuerunt quoad Regem Galliae, omnia prouenerint, et in me acta sint / a diuino spiritu; pro illa ueritate bene uoluissem sustinere tot mortes / quot habeo in corpore meo membra. /

[5] Continuatur in ea spiritus orandi totus diuinus, uidet in / Deo, pro quibus Deus uult orari; pro Ecclesia contra Iansenistas / contra imminentes haereses; quomodo oret. /

Vlterius spiritus orandi continuabatur in me multis horis, absque de- / ficientia uel flaccescentia, et absque eo, quod per aliquid possem im- / [10] pediri, siue 
Further it seemed that the Beloved required from me, that I would give his blessing to the French. Indeed I did so and I seemed in some way to curse our own army, by withdrawing all wisdom, courage and virtue from them. I did not do that on my own account, but the divine spirit seemed to operate that in me and through me, without me being able to prevent it.

She speaks in a familiar way with the angels for them to help the French, her intellect is united with the divine intellect, with the assurance of the divine working for the French.

In that time I also spoke very familiarly with the holy angels, as the helping spirits of my Beloved, committing to them all my care about handling, amplifying and establishing the kingdom of my Beloved, and I asked them to go there personally, and help them in their confrontations, those whom the Beloved had chosen for that purpose. This happened with great confidence trust and freedom of heart, so that I could not even for a moment doubt the truth of these things.

After that familiar talk and communication with the angels I was continuously drawn and pulled inwards in the aforementioned ... union, not only in the union of my spirit with the spirit of God, but ... the union of higher powers, namely of my intellect with the divine intellect, of my memory with the divine memory, of my will with the divine will. This is something different from what is usually called or named union with God. To explain this union many things occur that must be said, which time does not allow any more ... At the same time I was fully assured again that all those operations,

\section{$35 \mathrm{~V}$}

illuminations and ways of praying of the spirit etc, which have been in me for two years in relation to the King of France, all occurred and have been produced in me by the divine spirit. For that truth I would have well wanted to sustain as many deaths as I have members in my body.

The completely divine spirit of praying continues in her. She sees in God that for which God wants her to pray: the Church, against the Jansenists, against imminent heresies. So she prays.

The spirit of praying continued in me for many hours, without interruption or relaxation, and without being hindered by anything, whether I was reciting the 
cum aliis recitarem officium, siue hinc inde irem per / domum; nam ista oratio fit omnino in spiritu, per spiritum, et, meo / uideri, est plane supernaturalis; quippe omnes potentiae uidentur esse / suspensae a suis naturalibus operationibus, quam diu ista oratio / durat; ipsae se continent in quiete, et habent se permissiue. /

[15] Ista oratio est insolitus, efficax, et uiuus ad Deum intuitus, et conformis / ad ipsum amoris affectus; ubi anima non loquitur, nec supplicat, nec blande / deprecatur, nec aliquid repraesentat, nec expresse commendat aliquam / rem tamquam procul absentem, sed uidet in Deo uelut in speculo, ea, / pro quibus Deus uult orari; et Deus conformiter uidet in anima, ea, / [20] quae ipsa postulat, uel postulare uult, absque eo, quod ipsa expresse proponat / quid, aut quomodo; totum est conclusum et implicite, seu tacite, com- / prehensum in isto diuino intuitu, et pariformi amore Dei. /

Verumtamen anima bene scit, in quem finem spiritus taliter oret / et postulet; erat tunc pro conseruatione et amplificatione Sanctae / [25] Ecclesiae; in illo intuitu, seu aspectu et dilectione Dei etiam comitatur / quaedam feruens et urgens instantia, quae quasi cor diuinum uult penetrare / et ideo uoco istum aspectum efficacem et uiuum. /

Necessitas Sanctae Ecclesiae, quae mihi imprimebatur, partim erat / propter tumultus et commotiones, etc, quas Iansenistae causant in Sancta/ [30] Ecclesia, per eorum doctrinas apprehendendo magnam inhonorationem / contumelias, e[t] blasphemias contra Suam uirginem, et multos errores / quos ingerunt <cor>dibus fidelium; partim propter incursum Turcorum / partim propter interitum fidei in Hollandia plantari caeptae: etiam in hac / patria periclitantis; nam paucis diebus ante, dum accederem ad sacram/ [35] communionem, mihi ad uinum repraesentabatur iconomachia, et uiolationes / templorum, et sacrarum imaginum, quae uidebantur exerceri per haereticos / et a fide apostatas in his Prouinciis. /

Post quam repraesentationem ueniebat in me spiritus orandi, ad summa // 
liturgy of the hours with others, or I was going to and fro through the house. Because that prayer was given totally in the spirit, through the spirit and is, as it seems to me, clearly supernatural. For all powers seem to be suspended in their natural operations, as long as that prayer lasts. They find themselves in a state of quietness and devotion.

That prayer is an uncommon, efficient and vivid intuition in relation to God and corresponds to the affection of love that a person has for Him. There the soul does not speak or beg, nor does it pray blandly for forgiveness, nor does it represent anything, nor does it commend something expressly that is far away, but it sees in God as in a mirror those things for which God wants it to pray, just as if God sees in my soul those things for which it begs or wants to beg, without the soul proposing expressly to Him what and how. Everything is included and implicit or concealed, and comprehended in that divine look and in conformity with the love of God.

Still the soul knows well to what purpose the spirit prays and begs in such a way. It was then for the preservation and expansion of the Holy Church. That look or sight and love of God is accompanied by fervent and urgent intercession, which as it were wants to penetrate the divine heart, and therefore I call that sight efficient and vivid.

The necessity of the Holy Church, that was impressed upon me, was partly because of the uproars and commotions etc, which the Jansenists caused in the Holy Church, by their doctrines that they proposed as a great insult, criticism and blasphemy against the Holy Virgin, and the many errors that they thrust upon the hearts of the faithful..$^{38}$ Partly the necessity came to me because of the attack of the Turks ${ }^{39}$ and partly because of the destruction of the faith that had begun to be planted in Holland. Even in this country there was a danger. For some days before, while I went to holy communion, at the wine the iconoclasm was represented to me, and the violations of the temples and of sacred images, which seemed to be done by heretics and apostates from the faith in these Provinces.

After that representation the spirit of praying came to me,

38 Maria Petyt is a fervent opponent of Jansenism, which she saw as a heretical movement. She saw Jansenism and other heretics as a great danger for the unity of the Church. This is also the main reason why she chooses the side of the French, because she believes that the French want to bring back Holland - also a heretical country because of the dominance of Protestantism there - to the true faith of the Roman Catholic Church. 
$36 r$

[1] ista mala inuertenda, et deprecanda, per oblationem praetiosi sanguinis Christi / aeterno Patri; eadem oblatio mihi etiam mandabatur in praedicta ora- / tione, cum uariis adhuc aliis amoris inuentionibus, et amorosis allocuti- / onibus ad Jesum, et ad aeternum Patrem, quae mihi iam clare non occurrunt. /

[5] Sponsaliter agit cum Dilecto, et familiariter cum angelis, orans / pro ecclesia, et mandans caedere Caesarianos et Hispanos, / quos uidet nihil effecturos. /

Quando eodem tertio festo natalitiorum subinde tantisper remittebar / ab ista supermagna unione, et ponebar in dispositione, et statu amantis- / [10] simae sponsae, et familiaris, ac confidentialis conuersationis cum Dilecto / meo, ut dictum est, tunc manebam eleuata supra me ipsam, sed non / extra me ipsam, id est, habebam adhuc aliquam perceptionem mei ipsius in / Deo, et discretionem, seu distinctum cognitionem eorum, quae Dilectus in / me, et per me operabatur, et me uolebat operari, nempe attentissimum illum, / [15] et amorosum aspectum diuinae presentiae ipsius, istam orationem pro / Sancta Ecclesia, et oblationem praetiosi sanguinis Christi, conuersationem / et familiaria colloquia cum Sanctis Angelis, instar regalis sponsae cum / aulicis et nobilibus sui regalis Sponsi, agendo praecipue de rebus concernen- / tibus prosperitatem et promotionem regni Dilecti sui. /

[20] Idcirco cum a Dilecto meo intellexissem, quod Hispani et Caesariani ope- / rarentur et agerent contra ipsum et eius honorem, et gloriam etc, dabat / spiritus amoris mandatum Sanctis Angelis, ut istos exercitus profligarent, / et eneruarent, ipsis auferendo uires et animos, ne possent effectuare suum / intentum et propositum, in praeiudicium regni Dilect mei, Sanctae Ecclesiae. /

[25] Sentiebam quod hoc sic fieret; quod nostri Principes nihil efficerent, prout / ante Caroloreginum, ab illo tempore apparebat noster exercitus in mente mea / quasi congregatio muscarum, sine potentia, sine uiribus, quia Deus non erat cum / illis; Idem iterum renouabatur subsequenti die precum, quod n. nostri / Principes cum omnibus istis orationibus nullum a Deo acciperent auxilium. /

[30] haec scripsit 6 . Januarii 1674 , quando illa contigerant circa natalitia $1673 . /$ 
$36 r$

to turn aside that greatest evil and to pray that it would not happen, by the offering of the precious blood of Christ. That same offering was also demanded of me in the aforementioned prayer, with various other expressions of love and loving utterances to Jesus and to the eternal Father, that do not clearly occur to me anymore.

Like a bride she speaks with the Beloved, and familiarly with the angels, praying for the Church, and asking that the imperial forces and the Spaniards retreat, whom she sees will not reach any success.

When afterwards on the third day of Christmas I was somewhat released from that very great union, and I was placed in the disposition and state of a most loving bride, and of a familiar and confidential conversation with the Beloved, as it is said, then I remained lifted up above myself, but not outside myself, that is, I had still some perception of myself in God, and a discretion or distinct comprehension of the things, which the Beloved operates in and through me and which he wants me to operate. Namely the most attentive and loving sight of his divine presence, that prayer for the Holy Church, and the offering of the precious blood of Christ, the conversation and familiar talks with the holy angels, like a royal bride with the courtiers and nobles of her royal Bridegroom, preferably speaking about questions concerning the prosperity and promotion of the kingdom of her Beloved.

Therefore when I had understood from my Beloved, that the Spaniards and the imperial forces operated and acted against him and against his honour and glory etc, the spirit of love gave the order to the holy angels, that they should defeat and enervate those armies, taking away their forces and courage, so that they could not carry out their intention and plan of harming the kingdom of my Beloved and the Holy Church.

I felt that this happened like this. That our leaders did not achieve anything, like it was before Charleroi. ${ }^{40}$ From that time on our army appeared in my mind like a swarm of flies without power, without strength, because God was not with them. The same thing happened again on the next day of prayer, that our leaders with all their prayers would receive no help from God.

She wrote this on January 6 th 1674 , while these things happened during the days of Christmas in 1673 .

$40 \quad$ See n. 16. 
Imperatorem et Hispanos male facere assistendo Hollandis contra / Gallos, et Deum puniturum illos, qui Gallos impediuerunt in Hollandia. /

Reuerentia Vestra mihi asserit, quod Princeps noster tam bene intendat, et quod Imperator / sit pius uir; uerum, uti mihi uidetur, ipsi non faciunt pia [o] pera, sicut Zelosos, et / [35] Catholicos Principes decet, qui deberent armis suis uti ad .....em Sanctae / Ecclesiae, ad eradicationem haereticorum, etc; cuius contrarium nostri faciunt, impedi- / endo, quantum in se est, omnem profectum et propagationem sacrae nostrae fidei in / Hollandia, nec uoluerunt consentire, ut Hollandi cum Rege Galliae concordarent / cum titulo, et conditione permittendi templa Catholica in omnibus suis Ciuitatibus; / [40] uti dicitur et uero simile est, ex inuidia et maleuolentia, ne Rex Galliae haberet / honorem, quod in istis partibus sanctam Ecclesiam promouisset. / Ipsi impediunt, ne ille Rex gentem illam haereticam etc euertat, et regn............ //

$36 v$

[1] Jesu ibi plantet et stabiliat; et interim ipsi id non intendunt, cum tamen sit in / illorum potestate iam multas urbes haereticas pro se intercipere, uel apud status / praetendere libertatem fidei Catholicae in compensationem subsidii Hollandis / praestiti; quod iam uix ipsis posset recusari. /

[5] Sciat Reuerentia Vestra, quae seminauerunt nostri, haec et metent; Deus qui corda nouit / omnium, retribuet secundum opera eorum, et non secundum iudicium hominum, si / Imperator, et noster Princeps unanimiter cum Rege Galliae Hollandiam agg- / ressi fuissent, uel saltem sese continuissent, nullum Hollandis praestando subsidium / spatio medii anni Hollandia fuisset intercepta, et omnia cum bono ordine et pace, / [10] ualde Christiane processissent; pro ut Rex Galliae in principio incipiebat cum bono / zelo, pietate et laudabili regimine in populo suo; uerum praedicti nostri Princip[es] / in supremo gradu ei dederunt occasionem exacerbationis, et iracundiae; et inde / tam multa mala prouenerunt, et adhuc sequentur etiam in hac Patria, pro / ut ex nunc incipiunt. /

[15] Omnis conspiratio humana nihil ualet, quando Deus non uult cooperari, et(...) / Deus non cooperabitur, et in similibus non uult cooperari contra 
She says that the Emperor and the Spaniards do evil by assisting the Dutch against the French, and that God will punish them, because they impede the French in Holland.

Your Reverence assures me that our Leader conducts himself well, and that the Emperor is a devout man. But as it seems to me they do not do pious works, as would befit zealous and catholic leaders, who should use their weapons to ... of the Holy Church, to the eradication of the heretics etc. They do the contrary, impeding, as much as they can, the progress and the extension of our holy faith in Holland. They did not want to consent that the Dutch would come to an agreement with the King of France about the legal foundation and condition to permit Catholic churches in all its cities. As it is said and as it truly is, this was on grounds of envy and malevolence, so that the King of France would not have the honour of promoting the holy Church in these regions. They prevent the King from destroying those heretic people, and planting and establishing the kingdom

\section{$36 v$}

of Jesus there. And in the meantime they do not intend to do this, although yet it is in their power to already win over many heretic cities for themselves, as a compensation for the support given to the Dutch. That could hardly be refused to them.

May Your Reverence know that what our people have sown they will also harvest ${ }^{41}$, that God who knows the hearts of all, will recompense according to the works of each one, and not according to the judgement of men. If the Emperor and our leader, unanimously with the King of France, had attacked Holland, or if they at least had restrained themselves from supplying the Dutch with their support, then Holland would have been occupied in the space of half a year, and all would have been ended in good order and peace, in a Christian way, as the King of France began to do in the beginning with zeal, piety and laudable rule over his people. But our aforementioned leaders have, to the highest degree, provided the opportunity for bitterness and rage. And so many bad things have come forth from that and many things will follow also in this country, like those beginning already.

No human collaboration can achieve anything, if God does not want to cooperate, and ... God will not cooperate and in similar cases does not want to 
diuinam suam / dispositionem, et promissionem: quippe in spiritu saepe intellexi istud uerbum/ quando uidebam contrariam apparentiam alicuius boni successus etc contra / Regem Galliae, et in istum finem indicebantur multi dies precum etc, ad / [20] bonum successum sui propositi, et intenti, caelum et terra transibunt, uerba / autem mea non praeteribunt. /

Attamen ab aliquot hactenus mensibus, non uideo, quod Rex Galliae tanto / Dei fauores, et benedictionem mereatur, sicut antehac; quia Dilectus ( ) / nullum mihi de hoc dat signum, sed ex parte hoc me celat / [25] subinde mihi aduenit aliqua intima notitia seu suauis impressio in fundo animae / associata paruo et humili animo; quod Dilectus eo utatur, ut instrumento, qui / perferiatur id, quod sua Maiestas mihi promisit; secundum quod Reuerentiae Vestrae scripsi / significaui: et non obstante quod multi ualde male loquantur, et indicent de / isto Rege Galliae, tamen remanet aliquid diuinum scintillans in meo fundo, / [30] quod ipse cum tempore adhuc fiet ualde bonus, et Deo gratus.

Scripsit haec die 15. / Januarii 1674. /

Agitur spiritu orandi, ne Traiectum occupetur ab haereticis, et im- / perat Angelis, ut sponsa Jesu; et in festo S. Ludouici cogitur orare / pro uictoria Gallorum, quae succedit; conuentio cum hereticis / [35] prouocat iram Dei, quam praedicit. /

Reuerende et aman.... Pater, mihi adhuc aliquid uenit in memoriam, nempe quod / spiritus meus s....pere moueatur, et trahatur, ut efficaciter et amorose / agat, ad [ciuitatem] Traiectensem conseruandam sanctae Ecclesiae, ad quod / mihi infunditur uigorosus, et efficax spiritus orandi, iam fere quatuor/ [40] septimanis continuo per totum diem, absque relaxatione. /

Iste modus orandi exercetur modo singulari; non esset mihi possibile istum ad / talem orationem tractum annihilare, reiicere, uel dimittere; quippe secundum / omnem experientiam, ista oratio est plane supernaturalis extra propriam / [o]rationem; ideo tunc deprecor Ssmam Trinitatem cum mire humili / $[45](\mathrm{am} . ..) / /$ 
cooperate against his own divine disposition and promise. For in the spirit I often understood this word, when I saw the contrary appearance of success etc against the King of France, and for that purpose many days of prayer were indicated for the good success of his intention and plan: "Heaven and earth will perish, but my words will not pass." ${ }^{22}$

Still for some months now I do not see that the King of France merits so much the favours and blessing of God, as before, because the Beloved gives no sign to me about this, but he keeps it hidden from me. Right after that some intimate knowledge or pleasant impression comes to me in the depths of my soul, associated with a small and humble heart: that the Beloved uses him ${ }^{43}$ as an instrument, to complete what his Majesty has promised me. According to what I have written to Your Reverence, I have made it clear. And notwithstanding that many speak very ill and badly about that King of France, yet there remains some divine sparkling in my inner depths, that in time he will become very good and dear to God.

She wrote this on January 15 th $1674 .{ }^{44}$

She is led by the spirit to pray, that Maastricht will not be occupied by heretics, and thus she commands the angels, as the bride of Jesus..$^{45}$ And during the feast of St. Louis ${ }^{46}$ she is forced to pray for the victory of the French, which succeeds. An agreement with the heretics provokes the wrath of God, which she predicts.

Reverent and most beloved Father, to me something else has come to my memory, namely, that my spirit ... is moved and attracted, to speak powerfully and lovingly, to preserve the city of Maastricht for the Holy Church, to which end a vigorous and powerful spirit of praying has been infused in me, for almost four weeks continuously throughout the day without relaxation.

That way of praying is practised in a particular way: it was not possible for me who was drawn to such prayer to annihilate, reject or let it go. For according to all experience, that prayer is clearly supernatural beyond my own prayer. Therefore I then beg the most holy Trinity with a marvellous, humble ...

\footnotetext{
42 Mt. 24,35

43 I.e. the King of France.

44 In this document there are no letters from the period 15 January 1674 till 24 August 1676.

45 In 1676 Maastricht was still occupied by the French. From 6 July till 26 August 1676 William III besieged the city. It was not until the Peace of Nijmegen in 1678 that Maastricht became again part of The Dutch Republic.

46 The feast of St. Louis is on the 25th of August, feast of Louis IX, King of France in the period 1226-1270.
} 
[1] amorosa, et urgenti instantia; haec oratio habet diuersos modos, sed potissimum / spiritus cum humili demissione, sese coram diuina Maiestate quasi annihilando, / orat et postulat gemitibus inenarrabilibus, cum mire uiua fide, firma spe / exauditionis, et feruenti dilectione, absque multis uerbis, solum modo cum simplici / [5] repraesentatione, et aspectu ad Deum, modo essentiali implorando diuinam / uirtutem, et omnipotentiam, ac simul ministerium, et auxilium sanctorum / Angelorum, aliquando per modum mandantis, seu instar sponsae mandando / ministris Dilecti sui, ut istos sanctae Ecclesiae inimicos repellant, destruant, / profligent; hoc totum fit fiducialiter, cum sponsali confidentia, et ami- / [10] cabilitate, ac una cum magno zelo, et zelotypia ad curandum et pro- / mouendum interesse Dilecti, pro quo iam unice uiuit. /

Aliquando coram ssmo sacramento in extraordinaria, et insolita dispo- / sitione (nescio quomodo hoc nominabo, uel quibus uerbis explicabo) est ibi / spiritus quasi expansus, et attractus supra propriam suam operationem; ubi / [15] diuinus spiritus Jesu, istum superpurum, extaticum, et supra se raptum spi- / ritum tenet occupatum, et in eo operatur, ut oret et postulet, quatenus / ista Ciuitas possit remanere sanctae Ecclesiae. /

In festo Sancti Ludouici Regis, die 25. Augusti 1676, et die praecendenti, / saepius interius mouebar, et mouebar ad orandum, hoc modo, festina, et / [20] exoccupa te, ad orandum, quia iam tempus est; quasi iam aliquis conflic- / tus uel assultus fuisset prae manibus, uel in fieri, uel imminuisset: uidebatur/ spiritus tam diu in oratione debere perseuerare, quam diu iste conflictus, / seu assultus duraret; et postea intellexi, quod noster exercitus amiserit / conflictum cum internecione multorum militum, et uirorum illustrium, / [25] quantum existimo, eodem tempore, quo spiritus tam instanter interius moue- / batur, et instigabatur ad orandum. /

Reuerentia Vestra existimabat, quod si ista Ciuitas fuisset intercepta, cessisset Hispanis, / sed mihi uidebatur plane contrarium; nam in fundo meo erat aliud testi- / monium, quod iste rumor esset falsus: amantissime Pater, quid est mirum, / [30] quod Dilectus permittat cladem pro parte nostra? nam quam diu nostri / adhaerent, et suppetias ferunt isti impiae nationi, prouocant, et attrahunt / super se, et super Patriam, iram et indignationem Dei. /

Iam a pluribus annis uidi in spiritu, quod Deus istam unionem et con- / uentionem cum Hollandis mire reprobaret, et odio hab $<$ ere $>$ t, et ideo huic / 
loving and urgent intercession. This prayer has various forms, but preferably the spirit prays and begs with humble meekness, as it were annihilating itself before the divine Majesty, with ineffable sighs, with a marvellously vivid faith, a firm hope of being heard, and with fervent love, without many words, but only with a simple representation and vision of God, in a way that is essential to implore the divine virtue and omnipotence and at the same time the support and help of the holy angels, sometimes by way of ordering and like a bride ordering the servants of her Beloved, so that they might drive away, destroy and defeat those enemies of the holy Church. All of this happens intimately with the confidence of a bride, and with friendliness and at the same time with great zeal and effort to take care of and promote the concerns of the Beloved, for whom it ${ }^{47}$ has lived pre-eminently.

Sometimes in the presence of the most Blessed Sacrament in an extraordinary and exceptional disposition (I don't know how I should call this, or with which words I will explain it) there the spirit is in some way spread out and extended above its own operation. There the divine spirit of Jesus in that great purity, in ecstatic condition and as one risen beyond itself, keeps the spirit occupied, so that it prays and begs, to that extent that the city might remain with the Holy ChurchDuring the feast of the holy King Louis, on the 25th of August 1676 and the previous day, I was often internally moved and I was moved to pray in this way: "Hurry, and commit yourself to praying, because it's time already." As if already some conflict or assault was impending or happening or imminent. It seemed that my spirit should persevere for so long in prayer, as long as that conflict or assault would last. And afterwards I understood, that our army had lost the conflict with the loss of so many soldiers and illustrious men, as I believe, at the same time that my spirit was so insistently internally moved, and was instigated to pray.

Your Reverence believed that if that city had been occupied, it would go to the Spaniards, but it seemed clearly to me to be the contrary. For in my depths there was some indication that that rumour was false. Most beloved Father, no wonder that the Beloved allows our side to be defeated! For how long do our people cling to and support that impious nation and draw down upon them and their country the wrath and indignation of God.

For many years I have seen in the spirit, that God in a wonderful manner disapproves of that union and agreement with the Dutch ${ }^{48}$, and looks upon it

$47 \quad$ I.e. the spirit.

48 Probably Maria refers to the Quadruple Alliance of 1673. 
[35] quamquam innocentes id praecipue debeant luere; quomodo negocium / successit cum Comite Monti, cui etiam tanta comminatio facta est, / quia ipse ad istam unionem et conuentionem plurimum contulit, et / Hollandis suppetias dedit, cum pluribus aliis, qui non impune euadent. /fa xit Deus, ut punitio ipsorum sit tantum temporalis, et animae illorum / [40] seruentur. //

$37 \mathrm{v}$

[1] Deus ostendit potentiam suam in obsidione Traiectensi, / ne cedat haereticis, Angelis coöperantibus pro Gallis. /

Postea, Dominus Lucas Commissarius regius in nostro exercitu, nos / certiores fecit, quod noster exercitus recesserit a Traiecto, et cum / [5] infamia illam Ciuitatem deserere debuerit; sit Deus ideo benedictus, / o quam mirabiliter Deus ostendit omnipotentiam suam in ista obsidione / et quid possint illi, quorum Deus adiutor est; mira de istis dicuntur, / quae tamen abusiue magis tribuuntur generositati, et subtilitati Gallorum/ quam cooperationi, et auxilio omnipotentis. /

[10] Inter alia refertur, quod cuniculi a nostris facti ad euertenda fortalitia / Ciuitatis, ante tempus, accenso puluere tormentario, eruperint uersus nos- / trum exercitum, et magnam in eo stragem fecerint, plurimos mactando / nullo damno illato fortalitiis ciuitatis, uel Gallis, in eruptionibus ex / Ciuitate in nostros obsidentes milleni occidebantur in nostro exercitu, / [15] et pauci ex Gallis: Item fortalitia de die per explosionem tormentorum / bellicorum destructa, restaurabantur de nocte, in assultibus, quibus haeretici / aggrediebantur Ciuitatem, ad eam intercipiendam, uidebantur quasi quibus- / dam instrumentis omnium colla abscindi; ita ut spargeretur, numquam / simile quid fuisse auditum. /

[20] Existimo Sanctos Angelos hic fuisse in opere, et uelut fideles Jesu ministros / ista insolita, et mirabilia fuisse operatos et restitisse tot, et [tam...] horrendis / assultibus tam potentis exercitus. / 
with hatred, therefore, although they are innocent, they will have to pay for it in particular. How the affair with the Count of Mons has succeeded, to whom also such a threat has been made, because he has contributed very much to that union and agreement and has given support to the Dutch with many others, who will not get away unpunished. May God ensure that their punishment will only be temporal and that their souls will be saved.

$37 \mathrm{v}$

God shows his power in the occupation of Maastricht, that he doesn't yield for the heretics, while the angels cooperate at the side of the French.

Afterwards, Lord Lucas ${ }^{49}$, the commissioner of the King in our army, informed us that our army had withdrawn from Maastricht, and shamefully had to leave the city. ${ }^{50}$ Therefore God be blessed, o how wonderfully has God shown his omnipotence in that occupation and what could they do, whose helper is God! Miraculous things are said of them, that nevertheless unjustly are ascribed more to the generosity and attention of the French than to the cooperation and help of the Almighty.

Among other things it is said that the trenches that our people made to destroy the fortification of the city, have exploded, because the gunpowder was ignited prematurely, to the detriment of our army, and great destruction was caused by it, whereby very many were slaughtered without any damage done to the fortifications of the city or to the French. With the outbreaks from the city against our occupiers thousands of men were killed in our army and only a few of the French. Likewise the fortifications that in the daytime were destroyed by the explosion of the cannons were restored at night. In assaults, in which the heretics attacked the city in order to occupy it, it seemed that with some kind of instrument the necks of all were ripped off, in such a way that it was said that never had anything of that kind been heard before. ${ }^{51}$

I believe that the holy angels were working here, and that as the faithful servants of Jesus they operated these uncommon and miraculous things and resisted so many and so horrendous assaults from such a powerful army.

49 The full name of this commissioner is not retrieved.

$50 \quad$ See n. 45 .

$5^{1} \quad$ It is not clear to what kind of weapon Maria refers here. The description seems to be of the guillotine, but that was not invented before the French Revolution in the 18th century. More likely Maria mentions here a weapon like a musket or bayonet, which was developed in the 17th century and capable of killing many people in a short amount of time. 
Iam experior et uideo fuisse uerum id, quod mihi in fine mensis Aprilis / in spiritu fuit manifestatum, quomodo Deus sese poneret a parte exercitus / [25] Gallorum; quod ideo Rex Galliae esset futurus uictoriosus in omnibus suis / attentatis; non obstante, quod noster exercitus esset facile triplo numerosior / exercitu ipsius, tamen omnis ista multitudo mihi apparebat quasi multitudo / imbecillium muscarum, qui ubique succumberent. /

Veritas istius manifestationis, seu uisionis semper mihi remansit, et inhaesit / [30] sine ulla dubitatione, non obstante quacumque ...... ia apparentia, et / dictis hominum ....redo Reuerentiam Vestram adhuc me......... um quae de illis tunc / Reuerenti ae Vestrae di........... quam cum magna cauti[one] et uerecundia; quia Reuerntia Vestra / praesefe ............. splicetiam, inhibendo mihi, ne orarem; sed frustra est inhibitio / humana, quando Deus iubet, et ipsemet iussa operatur et exequitur in / [35] anima, et cum anima; arcana, dispositiones, et iudicia Dei sunt mirabilia, et / [ing] eniis humanis abscondita, ideo illa oportet uenerari, et adorari.

Haec scrip[sit] / ..... Augusti 1676 //

\section{$38 r$}

[1] Aduertentia circa ea quae transacta sunt in Venerabili Matre Maria / a Sancta Theresia tertiaria Ordinis fratrum Beatissimae Virginis Maria de monte Carmelo / tempore belli Gallici in Hollandia anno 1672 et sequentibus. /

Dum Rex Galliae maximo congregato exercitu Hollandiam inuaderet animo (ut pie credere / [5] licet) illam totaliter occupandi, et ad gremium Sanctae Romanae Ecclesiae reducendi, ualde frequen- / ter Venerabilis haec mater Maria a Sancta Theresia mirabiliter acta et directa fuit spiritu orandi / pro bono et optato istius belli successu; qualiter autem spiritus orationis et diuini amoris / in ipsa tunc operatus fuerit, et cum quali fructu, hic consequenter subiiciam ex ipsius / scriptis seorsim tamen a contextu reliquae uitae ipsius, ne forte aliquibus displaceant, et / [10] nimiae uariorum Criisi exponantur, quae an a diuino spiritu processerint nec ne, aliorum/ quorum est similia examinare, et 
Yet I experience and see that it was true, what was shown to me in the spirit at the end of the month of April, how God had placed himself on the side of the army of the French. That meant therefore that the King of France would be victorious in all his efforts, notwithstanding that our army was easily three times as numerous as his army. Nevertheless all that multitude appeared to me as a multitude of weak flies, that would succumb no matter where.

The truth of that revelation or vision has always stayed with me and stuck with me without any doubt, notwithstanding some ... appearance and the talk of men ... Your Reverence yet me ... that about these things then Your Reverence ... that with great caution and respect, because Your Reverence ... preventing me from praying. But human preventing is in vain when God commands and when He himself operates and carries out what he has commanded in the soul and with the soul. The secrets, dispositions and judgements of God are miraculous and hidden for human understanding. That is why they are to be venerated and adored.

She wrote these things on ... August 1676.

\section{$38 \mathbf{r}$}

Some remarks about the things that have come to pass in the Venerable Mother Maria of St. Teresa of the third order of the friars of the blessed Virgin Mary of Mount Carmel, at the time of the French War in Holland in the year 1672 and in the following years. ${ }^{52}$

When the King of France had gathered a very large army and invaded Holland with the plan (as one might piously believe) to occupy it completely and to lead it back to the womb of the holy Roman Church, very frequently this mother Maria of St. Teresa was miraculously driven and led by the spirit of praying for the good and desired success of that war. However, how the spirit of prayer and of divine love worked in her and with what fruit, I will explain here logically from her writings, but separated from the context of her life, so that it will not displease some people too much and ${ }^{53}$... and whether these things come forth from a divine spirit or not, I leave it up to others who are capable of

\footnotetext{
$5^{2}$ This is originally the beginning of the entire text, where Michael introduces Maria Petyt and the letters that she has written about the Dutch War. He begins here first with a short introduction in which he personally addresses the readers.

53 See article of Esther van de Vate, 92-118.
} 
ponderare iudicio reliquo; referam tamen illa, ea/ sinceritate, qua ab ipsa scripta sunt, et mihi concredita. /

Dilectus ei indicat Regem Galliae sibi facere rem gratum inuadendo Hollandiam / promittit uictoriam, et uult ut ipsa eum iuuet, uidetur Deus Hispanis minari / [15] quia iuuant haereticos; non tamen Regi, qui cum suo Regno, eius curae committitur. /

Die 3. maii 1672 sub oratione uespertina uidebatur Dilectus mihi significare, quod Rex Galliae / ipsi praestaret rem gratam inuadendo Hollandiam, cui etiam addicebat uictoriam. Dilectus mandabat / mihi, quod debuerim ipsi opitulari per orationes, et hoc sensu esse coadiutrix, et compugnatrix in ipsius / exercitu. /

[20] Verum Hispanis uidebantur fieri comminationes, eo quod Dilecto multum displicerent propter assiste.... / et copias auxiliares, quas praestant Hollandis, per quas quodam modo conant..... in....di..... ne Hollan....... / reducatur ad fidem Catholicam, sed uidebatur quod displicentia et com...... Dilecti non ......esse.... / praecise contra Regem aut Reginam, sed contra aliquos eorum consiliarios ..... inistro.... quia Reg...... / non uidebatur bene de rebus informata; ideo commendabat mihi Dilectus uti uidebatur..... / [25] ut in meam curam susciperem iuuenem Regi, et eius regnum, ut illud seruarem illesum......... / qualem finem spiritus amoris de nouo accipiebat nouum accessum zelum et consapientam / ut hunc iuuans .. 1

(.....) /

Die 4 dicti mensis renouabatur hic spiritus ........ / [30] ............ //

\section{$38 v$}

[1] Dilectus se ei exhibet laetabundum de instante occupatione Hollandiae, ostendit ei / feruorem nouorum Catholicorum et regnum suum dicit / etiam esse ipsius. /

Dilectus communiter et familiariter mecum agendo et conuersando, uidebatur inter / [5] alia ostendere magnam laetitiam, gaudium et iucunditatem, eo 
examining and weighing such things. I just refer to those things with the same sincerity in which they were written by her and entrusted on me. ${ }^{54}$

The Beloved informs her that the King of France does something that pleases Him by invading Holland. He promises the victory and wants her to help Him. God seems to threaten the Spaniards, because they help the heretics, yet not the King, whom with his kingdom is entrusted to her care.

On the 3rd of May 1672 during Vespers the Beloved seemed to indicate to me, that the King of France did a pleasing thing to Him by invading Holland, and He even promised him the victory. The Beloved charged me to help him by my prayers and to be in that sense as a helper and ally in his army.

But the Spaniards seemed to be threatened, because they displeased the Beloved very much due to the assistance ... and auxiliaries, which they have given to the Dutch, by which they tried in some way ... Holland ... was led back to the catholic faith, but it seemed that the displeasure and ... of the Beloved not ... was ... straight against the King or Queen ${ }^{55}$, but against some of their allies ... because ... seemed to be not well informed about things. Therefore the Beloved commanded me as it seemed ... that I should take care of the youth for the King 56 and of his kingdom, so that I would preserve it ... to such a purpose the spirit of love received anew access, zeal and wisdom ...

On the 4th day of that month this spirit was renewed ...

$38 v$

The Beloved manifests himself to her rejoicing in the imminent occupation of Holland; he shows her the zeal of the new Catholics and says that his kingdom is also hers.

The Beloved, commonly and familiarly speaking and interacting with me seemed among other things to show me his great joy, happiness and rejoicing,

54 From the beginning of this fol.38r until here it is Michael of St. Augustine who addresses the readers, from here on it is Maria again who writes her letters to Michael. Only the summarising parts are from Michael.

55 Maria refers to the King and Queen of Spain.

$5^{6}$ Charles II was born in 1661 and suffered from physical and mental disabilities. 
quod iam tempus aduenisset quo Hollandia / fieret Catholica; sicut aliquis, qui uni suo confidenti refert, et notum facit suum instantem honorem / et gloriam, quam ibi adepturus est per lucrum, et conuersionem animarum, quasi ad hoc anhelaret, ut / ibi uelut rex constituatur in plena possessione regni sui. /

Ipse mihi proponebat feruorem et sinceritatem, qua ibidem noui Catholici, ipsi seruient, et confite- / [10] buntur nomen sanctum eius: deinde uidebatur mihi dicere, regnum meum erit etiam regnum tuum / meus hon or erit etiam tuus, mea gloria tua gloria. /

Animatur ut iuuet Exercitum Gallorum et animat ad pugnandum pure pro fide / et fertur erga illos spiritu amoris. /

Per hanc familiarem cum Dilecto Conuersationem magis in corde meo accendebatur ignis diuini / [15] amoris cum zelosis et feruentibus desideriis et affectibus ad iuuandum exercitum Gallorum eosque exci- / tandos et animandos ad zelotypum zelum pure et simpliciter praeliandi et pugnandi pro fide. /

Hic ignis amoris agit et impellit spiritum amoris in praedicto exercitu, nunc apud efficiarios, nunc / ad gregarios milites ad eos extimulandos, animandos et confortandos in amore Christi, ut corpus animam / ........ afferant et exponant ad obsequium Jesu; quo sic eum iuuent ponere in solio regni sui, profli- $/$ [20] ...... et indedii... endo expellendo, et delendo omnes eius inimicos: zelosi affectus quibus spiritus / amoris hic occupatur sunt magni et singulares, attamen cum bono ordine, et bene regulati. /

Deus uult ab ipsa orari pro Rege Galliae cuius mala uita ei manifestatur, et / quantus illi Deus sit offensus; orat pro eo cum spe exauditionis. /

Feria 2 Pentecostes 1670 existens in oratione intelligebam deum uelle orari pro Rege Galliae / [25] ...... to sum....per tangebar in corde meo ut pro illo orarem 
because the time had already come that Holland would become Catholic. Like someone who tells and notifies his imminent honour and glory to a confidant, which $\mathrm{He}$ will acquire there by the winning and converting of souls, as if $\mathrm{He}$ was yearning to be constituted as King in full possession of his kingdom. ${ }^{57}$

He put me in mind of the enthusiasm and sincerity with which the new Catholics there ${ }^{58}$ would serve him and would confess His holy name. Then $\mathrm{He}$ seemed to say to me: "My kingdom will be also your kingdom and my honour will be also yours and my glory your glory."

She is animated to help the King of the French and she animates them to fight purely for faith and she is driven towards them by the spirit of love.

By this familiar interaction with the Beloved a fire of divine love was ignited more in my heart with zealous and fervent desires and affections to help the army of the French and to encourage and animate them to a zealous zeal purely and simply to fight and battle for faith. ${ }^{59}$

This fire of love leads and impels the spirit of love in the aforementioned army, sometimes with the executive officers, then again with the ordinary soldiers, to stimulate them and animate and comfort them in the love of Christ, so that they bring body and soul ... and expose them to the obedience of Jesus, in which way they help to place Him on the throne of his kingdom, defeating, ... expelling and destroying all his enemies. The zealous affects by which the spirit of love is occupied are great and singular, nevertheless in good order and well regulated.

God wants her to pray for the King of France whose bad life is shown to her, and how God is offended by him. She prays for him with the hope of being heard. ${ }^{60}$

On the second day of Pentecost 1670 while I was in prayer I understood that God wanted me to pray for the King of France ... I am ... I was touched in my

$57 \quad$ This seems to be the main argument why Maria Petyt believes that the Beloved chooses the side of the French, namely so as to help Him recapturing his Kingdom in Holland.

58 I.e. in Holland.

59 Explicitly Maria states here that she wants this war to be purely fought with motives of faith and not with hate or bloodlust.

6o Here Michael inserts a fragment of a letter written on the second day of Pentecost, 1670. This day Maria understood that God wanted her to pray for Louis XIV. 
etiam cum lacriimis quatenus de- / ..... mala et scandalosa uita et perueniat...... ueram et ....am uitae emendationem mihi / ....... et ... ..... quod ipse causat........ / $(\ldots . ..) / /$

[1] anima a Dilecto commendatur, ut pro illa orem, hoc subito et quasi in instanti apprehendit meum cor / animum et affectum, instar scintillae ignis in fomite, et manet ibi scintillare, nec extinguitur; quod dum per- / cipio, sum quasi certa, quod ista sit mihi data, et pertinebit ad me. /

Die 4 maii 1672 renouabatur mihi memoria, quod a duobus annis uel circiter Dilectum ualde instan- / [5] ter rogauerim pro Rege Galliae, quando tam male uiuebat, et postulabam a Dilecto hanc animam, ut illam mihi / uellet donare, quam ipse mihi etiam promittebat; et de facto mihi dabat: atque intelligebam, quod praesens ipsius / bonus zelus instar seminis seu scintillae, iam in corde ipsius caeperit scintillare et operari. /

Orans Jesum ut benedicat exercitui Gallorum iubetur illi etiam dare benedictionem / ut sponsa et compar Jesu: materno corde est pro illis sollicita, et utitur ad hoc / [10] obsequio Angelorum. /

Quando semel Dilectus meus ualde familiariter mecum agebat sicut amantissimus sponsus cum sua / charissima sponsa, multa et multiplicia ad ipsum habebam alloquia, quae omnia annotare est mihi impossibile. / Inter alia ipsum orabam, ut exercitui Gallorum uellet dare suam benedictionem; et ipse uicissim mihi dicebat / Da tu etiam illis tuam benedictionem, quia tu es consors mea, et uolo tibi iuxta me facere istum honorem: tunc / [15] dicebam cum Apostolo Petro; Dilecte in uerbo tuo id faciam et illis benedicebam in hunc modum omnipotentia / patris, sapientia filii et amor spiritus sancti sit uobiscum ad superandos ecclesiae hostes, amen. $/$

Die 26 maii 1672 et diebus praecedentibus, fruebar subinde intima tranquillitate, subinde etiam ...... / spiritu orandi, cum libero accessu et confidentia ad Dilectum quasi materno corde occupata .... / exercitu Regis Galliae, ne ipsis deficiunt necessaria uel animi ad persequendum, et prospere exequendum id 
heart to pray for him even with tears, in as far as ... the bad and scandalous life ... would come to ... an improvement of life for me ... and that he causes ...

The soul is commanded by the Beloved to pray for those things. Straightway and as if at that instant my heart gained courage and feeling, like a spark in the fireplace, that remains shining and does not go out: While I perceive that I am nearly certain that this is given to me and will affect me.

On the 4th of May 1672 my memory was renewed, that for about two or three years I have prayed to the Beloved very urgently for the King of France, when he lived so badly, and I commended that soul to my Beloved, so that he would want to grant to me what he himself promised me. And in fact he gave it to me. And I understood that there was fine zeal in him like a seed or a spark, that already began to glow and operate in his heart.

While praying to Jesus that He might bless the French army she is commanded to give them also her blessing as the bride and equal of Jesus. With a maternal heart she is concerned about them and hence she uses the obedience of the angels.

When once my Beloved spoke very familiarly with me like a most loving bridegroom with his dearest bride, I had many and varied conversations with him, of which it is impossible for me to write them all down. Among other things I prayed to him that he might give the army of the French his blessing. And he in turn said to me: "You give them your blessing, because you are my equal, and I want you to be with me in making that honour." Then I said with the Apostle Peter: "Beloved, on your word I will do that". ${ }^{11}$ And I blessed them in this way: "The omnipotence of the Father, the wisdom of the Son and the love of the Holy Spirit be with you so as to overcome the enemies of the Church. Amen." ${ }^{62}$

On the 26th of May 1672 and the previous days, I enjoyed then an intimate tranquillity, then also ... the spirit of praying, with free access and confidence to the Beloved, as with a motherly heart concerned ... about the army of the King of France, so that they might not lack the necessary things or the courage to persevere and to bring to a successful end what they already had begun to

\footnotetext{
61 Cf. Mt. 14,28.

62 Unknown blessing.
} 
quod / [20] iam aggredi coeperant in Hollandia: ad quod utebar obsequiis Sanctorum Angelorum accepta ad hoc fiducia, / et certa confidentia, etenim spiritus amoris manet ad hoc stabiliter inclinatus, ut pro ipsis sit sollicitus / pro illis oret etc eo quod id adeo concernat maiorem Dilecti mei honorem, gloriam et beneplacitum / salutem plurimam animarum. /

Videtur sibi esse grauida omnibus animabus in Hollandia conuertendis quas / [25] quasi a Dilecto concepit, ut sit illarum mater sicut ipse est Pater, quas Christo / parturit materno affectu distribuendo illis dona gratiarum. /

Postridie Ssmae Trinitatis 1672 uidebatur mihi, quod essem quasi spiritualiter impregnata orbus animabus / in Hollandia ad fidem Catholicam conuertendis uidebatur omnes illas in corde meo habere conclusas, et quod hoc / sensu illas ut fetus spirituales a Diuino amatore meo concepissem, et ipse me uellet facere spiritualem ..... / [30] matrem sicut ipse erat earum Pater. /

Confirmatio uidebatur iterum esse renouata quod essem consors Dilecti, et de facto haberem ..... haer.... / et praetenerum affectum erga omnes istas animas --------------- ut eas Gro......... / amoris erat ualde fluidus amabilis ....... et uigorosus in operando .....ebantur ex........ / ...mae in ...... est ab animis praeferrem / [35] Sentiebam quasi mihi dari confidentiam a Dilecto perire diuinos .......... / domum fidei et alia dona spiritus sancti pro libitu distribuenda infidelibu....... / decreuerat illuminare dono et lumine toriae fidei; sed illud opus non ......... / amabilem in auxilium, seu potius ut ipsa dignaretur ista dona distribue.......... / ut sic omni optatum melius sortinentur effectum, utpote cum hoc.......... / [40] cui ego uelut eius ancilla illas animas adferrem. /

Hoc procedit cum mire amicabili confidentia uiua spe .......... / [di]gnatio sit a . //

$39 v$

[1] Acta spiritu amoris confidenter agit cum Dilecto ut eius consors de conuersione animarum / istarum, ut se sponte subdant Regi Galliae, ut mittantur operarii boni, occupatur circa / illas, ut uera mater, ut pariat, nutriat etc. Dilecto eam ad hoc animante./ 
attack in Holland. Thereto I used the obedience of the holy angels, the faith that I had received up to now and the certain confidence, for the spirit of love remains stably inclined towards this, so that there is concern about them and prayer for them etc., because it concerns so much the greater honour of the Beloved, his glory and pleasure ... the salvation of very many souls.

It seems to her that she is pregnant with every soul in Holland in order to convert them, whom she as it were has conceived of the Beloved, so that she is their mother like He is their Father, and to whom she has given birth with a maternal affection while bestowing on them the gifts of grace.

The day after the feast of the Holy Trinity ${ }^{63} 1672$ it seemed to me that I was as it were spiritually impregnated so that I might convert all parentless souls in Holland to the catholic faith, and it seemed that I had all of them in my heart, and that with this feeling I had conceived them like spiritual offspring of the divine lover, and that He wanted to make me their spiritual ... mother like He was their Father.

The confirmation seemed to be renewed again, that I was the companion of the Beloved and that I in fact had ... and a tender feeling towards all those souls ... of love was very fluid, loving ... and vigorous in operating ...

I felt like some confidence was given to me by the Beloved ... the divine ... the house of faith and other gifts of the holy spirit to be freely distributed among the unbelievers ... decreased to illuminate with the gift and light of ... the victory of faith. But that work not ... loving to the help, or better so that she is deemed worthy to distribute those gifts ... so that they sort out the effect wished by all, as with this ... to whom I bring those souls like his servant. This proceeds with an extraordinary, loving confidence, with vivid hope ...

\section{$39 v$}

After the spirit of love had spoken she speaks confidently with the Beloved as his companion about the conversion of those souls, so that they voluntarily surrender to the King of France, so that good workers are sent. She is concerned about them, like a real mother, to give birth to them, to feed them etc., while the Beloved enlivens her in this.

63 I.e. the 12 th of June 1672 . 
Spiritus amoris tunc miscet cum Dilecto multa et sponsali confidentia plena colloquia uelut cum suo / [5] consorte, ut omnia necessaria ordinentur et disponantur pro istis apparenter conuersis et conuertendis / animabus uerbi gratia ut cito conterantur et emolliantur, nec maneant obstinatae, et obduratae, ut se facilius / subiiciant Regi Galliae, ne alioqui tam multi in sua infidelitate et erroribus moriantur etc. /

Item ut illi complaceat mittere idoneos et zelosos operarios in hanc suam uineam, quos donis spiritus sancti / decorare et aptare dignetur ut pauco tempore multa opera praestent et copiosos fructus adferant, tunc / [10] nihil uidetur mihi recusari; sed omnia ad uotum concedi, nam ipsemet Dilectus meus excitat in me haec / zelosa, blandientia seu urgentia desideria, plena materna sollicitudine et dilectione, ut sic eum amorose / cogam prouidere de omnibus ad animas istas spiritualiter pariendas et ad salutem educandas necessariis: ad / hoc dat mihi Dilectus persuauem confidentiam seu potius ipse me ad hoc uidetur allicere ut materno meo corde / et erga istas animas affectui dem libertatem. /

[15] Quando spiritus amoris hoc percipit, facit maternum cor quasi dilatari cum suaui amicabilitate et amore / easdem quasi supercomprehendendo et superamplectendo ac cum aliqua diuina uirtute attractiua (quae / tunc ....i conceditur) easdem sic congregando et concludendo in meo amantissimo corde, cum intentione zelo / .........siterio illis incubandi, eas calefaciendi, enutriendi et praeseruandi ab omnibus earum salutem impe- $/$ dientibus uel retardantibus eodem modo sicut gallina cum pullis suis, tunc eius spiritus ueraciter / [20] habet indolem et inclinationes gallinae erga pullos suos. /

Agitur efficaci spiritu orandi pro conuersione peccatorum et Rege Galliae, Dilectum / quasi urgendo et cogendo et uidetur Dilectus correspondere uotis. /

Spiritus orandi plerumque est ualde uigorosus et efficax tam pro conuersione animarum, quam pro adiutorio / Regis Galliae, spiritus subinde habet quasi fortem, et efficacem, attractionem et impulsionem usque in cor diuinum / 
The spirit of love exchanges then with the Beloved many conversations full of bridal confidence like as if to his companion, so that all necessary things are ordered and disposed for those who are apparently converted and for the souls who must be converted, e.g. that they might be quickly exhausted and weakened and not remain obstinate and persistent, that they might easily submit to the King of France and that not so many might die in their infidelity and errors etc. 64

Likewise it pleases Him to send suitable and zealous workers to this vineyard, whom he deems worthy of decorating and honoring with the gifts of the holy spirit, so that they in no time do many works and bring forth copious fruits. ${ }^{65}$ Then nothing seems to be refused to me, but all is granted to me in accordance with my prayer. For my Beloved himself arouses in me these zealous, charming or urgent desires, full of maternal concern and love, so that I urge them lovingly to take care of all things necessary so as to give birth to those souls spiritually and to nurture them to their salvation. To this end the Beloved gives me a pleasant confidence or rather He seems to attract me so that I give free rein to my maternal heart and affection towards those souls.

When the spirit of love perceives this he causes my maternal heart to be extended with pleasant friendship and love, embracing and surrounding them and by some divine attracting power (which then ... was permitted) and gathering and enclosing them in my very loving heart, with the intention, zeal ... to watch over them, to warm them, to nourish them and to protect them against all that might hinder or retard their salvation like a hen with her chicks. Then of course his spirit has truly the natural ability and inclination of a hen towards her chickens. ${ }^{66}$

She is led by a strong spirit of praying for the conversion of the sinners and for the King of France, as it were urging and forcing the Beloved, and the Beloved seems to answer her prayers.

The spirit of praying is mostly very vigorous and strong both for the conversion of souls and for the help of the King of France. The spirit has as it were a strong and powerful attraction and impulse to the divine heart. This happens through

64 It should be noted that Maria Petyt is not so much praying against the Spanish soldiers and against the people in Holland, but is instead praying for the conversion of those souls, to bring them back to what she sees as the true Catholic Church. She even hopes that they will not die before being converted.

65 Cf. Mt. 9,37-38; 20,1-16; Lc.10,2.

66 Cf. Mt. 23,37; Lc. 13,34. 
[25] hoc fit per aggressiuum, fortem, uigorosum amorem, qui ualde subtiliter et spiritualiter operatur in fundo animae / magis infusus quam ipsemet operatiuus. /

Est ipsemet ignis amoris, qui tunc ardet in fundo, et hanc attractionem seu appressionem facit usque in cor diuinum / tunc est in anima praemagna propinquitas et intima perceptio seu experientia diuinae praesentiae intus / in me absque ullo medio, quasi apprimendo etc. /

[30] ..... o hoc sit tunc percipere et experiri seu intime comperire licet aliquis diuinae praesentiae effectus / ..... ut quas, correspondet isti expressioni animae uotis annuendo ac se ad animam inclinando, quasi ipsi / .............. mplectendo, et insinuendo per concordiam mutuorum desideriorum, per conuenientiam suam / .tum. /

liquo tempore in absorptione et unione cum Deo attamen subinde ex /

[35] dilectione euigilando iterum incipit se occupare in ista uigorosa appressio do- /

liquum ad quiescendum in se in puria solitudine spiritus et tranquilitate / loquando erinttiterius spiritum id locarinota ubi est necessitas spiri- / .rtum de illa ....xit ad uarios effectus / uc alios in me habet effectus, ..o quod speciali uirtute ac uehementia/ [40] .oca procul rer....a uerbi gratia ad praedictum exercitum Gallorum uel alio / animarum spiritus

$($.........) $/ /$

40r

[1] Hoc agitur, uel fit in me non per modum naturalium cogitationum uel imaginationum, sed quasi spiritus eo trans- / portaretur per impulsum amoris eodem modo, sicut glans ferreus e tormento bellico propellitur ui ignis et pulueris / tormentarii ad loca remota, et ibi operatur miros et peregrinos effectus, nam eodem modo spiritus tunc per / uolentiam extraordinarii ignis amoris, et diuinae uirtutis expellitur, seu emittitur; quae diuina spiritus comitatur / [5] spiritum in operando, quasi unanimiter simul cum spiritu cooperando; et quidquid, tunc spiritus attingit uel / ubicumque approquinquat ibi quasi exit ab ipso quaedam uirtus se ipsam communicando. /

Hanc experientiam et deprehensionem quomodo haec uirtus exeat ex spiritu, et quomodo ipse sese communicet, non possum / aliter explicare; nisi quod experior, quod quasi quaedam uirtus de me exeat, quocumque tunc spiritus aduenerit uel / quidquod attingerit, quo tempore benedicerem cum Jesu, quando illa mulier ipsum tetigerat, quis me tetigit; quia uirtus / [10] de me exiuit. / 
an aggressive, strong, vigorous love, that operates very subtly and spiritually in the depths of my soul, more infused than self operated. It is the fire of love itself, that burns then in the depths of my being, and causes this attraction towards or pressure upon the divine heart. Then there is in the soul a very great proximity to and intimate perception of the divine presence inside me, without any medium, as it were impressed in me etc.

... this is then to perceive and experience or intimately sense, although some effect of the divine presence ... corresponds with that expression of the soul that grants the prayers and inclines to the soul, as it were him ... and penetrating through the concord of mutual desires, through his agreement ...

... some time ... in the absorption and union with God still immediately out ...

... by love awakened begins again to occupy itself in that vigorous pressure ...

... to the rest in itself in pure solitude of spirit and tranquility ...

$\ldots$

40r

This is done or happens in me not in a natural way of thoughts and imaginations, but as if the spirit is transported there by an impulse of love in the same way as a iron bullet is shot out of a cannon by the power of fire and gunpowder to faraway places, and there miraculous and strange effects are brought about. For in the same way the spirit then, by the violence of an extraordinary fire of love and of divine virtue, is poured out and sent forth. That divine spirit accompanies the spirit in operating, as it were unanimously working at the same time with the spirit. And whatever the spirit then accomplishes or approaches, there, as it were, some power comes out of it that communicates itself.

This experience and grasping how this power comes out of the spirit and how it communicates itself I cannot explain otherwise. Except that I experience that as it were some power comes out of me, and wherever then the spirit arrives or whatever it touches, at that same time I blessed with Jesus, as when that woman had touched Him: "Who has touched me, because a power has come out of me." ${ }^{67}$

67 Cf. Mc. 5,30; Lc. 8,45-46. 
Dilectus ponit Regem Galliae in eius corde tamquam filium; Rex Hispaniae quasi alienatus / pro aliquo tempore, et eius regnum quasi obscuratum in eius animo, postea Rex Hispaniarum / iterum intromissus in eius corde ambo sustunti et quasi gemini eius filii. /

Dilectus intromisit Regem Galliae in corde meo et spiritus amoris aliquando habet multa agenda cum illo / [15] uelut cum meo filio, quae confido per Christum in Christo rege misse. /

Rex Hispaniarum circiter duobus mensibus fuit alienatus a meo spiritu amoris et eius regnum aliqualiter / obtenebratum in animo meo; quod me parum mouebat, et sentiebam compassionem cum illo, quia timebam ... esse / signum alicuius displicentiae dei uel mali successus, uel futurae punitionis regno eius imminentis .... / [u]erum necdum in uno uel in alio sum omnino certificata, sed intilenis rex uidetur iterum intromissus .. cor.. mea / [20] [e]t spiritus amoris uidetur hos duos reges ualde amicabiliter circumplecti, ut eos simula..... et ..... / ...uicem iuuat; sed quando et quo modo haec unio in ipsis fiat necdum uideo, nec intelligo ambo sunt aeque / suaues et amabiles in mente mea, quasi duo gemini filii, qui sunt mei et ad me pertinent. /

Isti modi orandi et operandi sicut cum collusione partis sens....ae suo directione / spiritus secundum lumen diuinum quo fit, ut ubique occuratum ... diuinae essentiae /

[25] Omnes hi modi orandi et operandi spiritus amoris fiunt cum uiuacitate et cooperatiue ...entiarii sensi / ....ruarum et simul rationalium; attamen illae potentiae non operantur plus uel uiuacius quam spiritus eorum / [o]bsequio iudigeat; spiritus manet suprema ...., illas impedendo et dirigendo secundum exigentiam et / [p]lacitum; unde omnes animae potentiae manent [ben]e ordinatae et regulatae dilita ...ndordinatione ad spiritum/ principalem et quo spiritus subiectione erga Deum uel sub nirmid uotionae directione etc. diuinae ............... / [30] in anima lucentis. / [Ab]iecta, quae tunc animae proponuntur uerbi gratia ambo illi reges, illorum regnum exercitu ............. / [s] ensibilia corpora et in speciem multiplicia uerumtamen .......ndo spiritus sic est / diuino lumine, tunc statim ... /

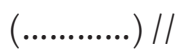


The Beloved places the King of France in her heart like a son. The King of Spain seems to be alienated for some time, and his kingdom is as it were obscured in her mind. Then the King of the Spaniards is let in to her heart again, and both Kings are lifted up and are like her twin sons.

The Beloved sends the King of France into my heart and the spirit of love sometimes has many things to do with him like with my son. I trust that they have been sent to the King through Christ and in Christ. The King of the Spaniards has been about two months alienated from my spirit of love and his kingdom was somewhat obscured in my mind. That did move me a little, and I felt compassion for him, because I feared ... to be a sign of some displeasure of God or of a bad outcome or future punishment that threatened his kingdom ... but I am not yet totally assured of the one or the other, but ... the King seems to be sent in again ... my heart ... and the spirit of love seems to embrace those two Kings in a very friendly way, so that ... them ... and one another... helps. But when and how this union in them will happen I do not see nor understand. Both are equally pleasant and friendly in my mind, like two twin sons, who are mine and belong to me. ${ }^{68}$

Those ways of praying and operating like with the collusion of a part ... in his direction, the spirit according to the divine light, by which it happens that everywhere occurred ... to the divine essence.

All these ways of praying and of operating of the spirit of love happen with vivacity and cooperatively ... and at the same time rational. Nevertheless those powers do not work more or more vividly than the spirit of them ... The spirit remains supreme ..., impeding them and directing them according to the demand and the agreement. Therefore all powers of the souls remain well ordered and regulated ... to the principal spirit and with which the spirit by the subjection to God or under ... direction etc., divine ... in the soul of the one who enlightens

68 It is clear that she longs for some kind of union between the two Kings of France and Spain. She wants them both on the same side, to strive together for the Kingdom of God on earth. 
40v

[1] Accipit spiritum orandi adhuc nobiliorem a diuino spiritu, qui simul cum / eius spiritu orat modo inenarrabili. /

Sabbato post festum Sanctissimi Sacramenti, accepi spiritum orandi ualde diuersum a praecedenti; etc. / meo iudicio est multo nobilior, sublimior, et perfectior, nec etiam minus efficax, immo potius / [5] efficacior, eo quod diuinus spiritus meo spiritui unitus, hanc orationem ipsemet operatur, et fere omnia / in me, mecum et per me faciat. /

Etenim diuinus spiritus uidetur me tunc possidere, in me uiuere, et per me orare modo ineffabili, tunc / uenio in notitiam istius quod ait Apostolus de oratione diuini spiritus in nobis, ipse spiritus postulat in nobis / $\mathrm{g}$ emitibus inenarrabilibus; per quod Apostolus non uult dicere uel significare, quod spiritus gemebunde / [10] oret uel quod illius gemitus sint tam multiplices, ut sint innumerabiles, et ineffabiles, sed uult dicere, quod / modus orationis, quo spiritus in nobis orat, sit inenarrabilis. /

Atque hoc uerum est, quia quando me deprehendebam a spiritu Dei sic possessam, singulariter coram, directam / et intime cum illo unitam, et quod diuinus spiritus in hac cum meo spiritu unione inciperet orare, raro etc. / numquam antea probato modo, tunc aperte intelligebam, quod hi essent gemitus inenarrabiles spiritus, de / [15] quibus l<oqui>tur Apostolus. /

Dictus modus orandi fit per eleuationem spiritus ante faciem Dei; tunc / spiritus Dei unitus spiritui eius orat pro Rege Galliae quem spirituali / modo uidet in Deo, ut in speculo. /

O qu........ ille modus orandi, quid adferam, ut de illo aliquid dicam Reuerentiae Vestrae faciam quod potero / to committam ....ta oratio fiebat in aliqua ..ertatione spiritus, semel sub recitatione ho- / [20] faceram communionem; uidebatur mihi quod in hac eleuatione spiritus starem ante / faciem Dei ........ erius operationis, aut perceptionis animae, nisi uisionis seu intuitus Dei; hoc / uiuere hoc int..... amare et orare modo ineffabili; et spiritus Dei meo spiritui unitus id in me / faciebat se illud .......ere amare, orare seu ipse aspicerebat, amabat et orabat. / 


\section{V}

She receives from the divine spirit a spirit of prayer that is more noble, that prays together with her spirit in an ineffable way.

On Saturday after the feast of the holy Sacrament ${ }^{69}$ I received a spirit of praying very different from the previous etc. In my opinion it is much more noble, sublime and perfect and not less efficient, on the contrary rather more efficient, because the divine spirit is united with my spirit. He himself operates this prayer and does almost everything in me, with me and through me.

And indeed the divine spirit seems to possess me then, and live in me and pray through me in an ineffable way. Then I become known by what the Apostle said about the prayer of the divine spirit in us: "The spirit himself intercedes in us with ineffable sighs." ${ }^{\prime 0}$ With that the Apostle does not want to say or signify that the spirit prays sighing or that his sighs are so multiple that they are uncountable and ineffable, but he wants to say that the way of praying, with which the spirit prays in us, is ineffable.

And this is true, for when I found myself possessed by the spirit of God, singularly directed to Him and intimately united with him, and that the divine spirit in that union with my spirit began to pray, in a strange etc, and never before experienced way, then I understood clearly that these were the ineffable sighs of the spirit, of which the Apostle speaks.

The aforementioned way of praying happens by the elevation of the spirit before the countenance of God. Then the spirit of God united with her spirit prays for the King of France, whom she sees in a spiritual way in God, like in a mirror.

O how ... that way of praying, that I do, so that I may say something about him to Your Reverence, and do whatever I can ... entrust ... prayer happens in some ... of the spirit, once under the recitation of the Hours ... I received communion. It seemed to me that in this elevation of the spirit before the countenance of God ... of the operation or of the perception of the soul, unless of the vision or sight of God. To live that, to ... to love and to pray in an ineffable way. And the spirit of God united with my spirit did that in me that he ... to love, to pray or He saw, loved and prayed.

\footnotetext{
69 The feast of the holy sacrament was on the Thursday after the feast of the holy Trinity. In 1672 this was on June 16,1672 . The Saturday after that was June $18,1672$. 
.uero eram ad ...... abstracta, et absque imaginationibus omnium quae sunt extra Deum; ego nihil aspi- / [25] .....eram nihil cogni............dium, id pro quo spiritus orabat, erat Rex Galliae, pro adiutoria et assistentia / ....ipsius in sua....... ciene reducendi Hollandiam ad fidem Catholicam; huius rei habebat spiritus / ...........ssima.......quam ....... tiam quasi sine corpora, uel imaginaria repraesentatione uel cogitatione / ........quod ...... tiua hic non cooperaretur, et consequenter ipsa non haberet corpoream / ...........ligu...m seu repraesentat .... imaginariam istius Regis aut alterius rei; sed intellectus passiuus / [30] ...... conuerger..... contemplans et simul ille intellectus passiuus uidebat et / quod spiritus ......... in Deo, in nuditate cogitationum seu imaginationum seu/ cogitationibus ..non possum ... explicare./

mihi caten........sicut aliqua ......ea duntur, et uidentur in speculo / per hoc a uisione contemplation Dei medietur aut ullatenus im- / [35] repraesentatio Regis et proposie ....................erum in diuina essentia ........in speculo mationem...........gratias dicto Regi conferri / seu interati ipsius erabit omnino/ ........................orum in diuina essentia ................... sratias dicto Regi conferri / in speculo manifestatum et reprae- / . /

[1] Videbam et percipiebam quod ista oratio haberet magnos effectus, et ui illius isti Regi affluerent multae / gratiae diuina auxilia, et diuinae cooperationes in presequendo et exequendo ipsius proposito et intento; / clare etiam intelligebam quod Deus illi uellet largiri istas gratias, et diuina auxilia subministrare ac ad / intentionem Regis cooperari mediante tali oratione, et non aliter, et quod Deus ad hoc assumeret et elegeret / [5] aliquas paruas et humiles ac simul puras et Deum sincere amantes, ut pro illis orent inter / quas paucas uidebatur sua maiestas me indignam etiam uelle impendere, audere autem dicere quod / Dilectus mea solius opera uel oratione ad hoc uelit uti, uideretur mihi intollerabilis praesumptio, quamquam / interna Dilecti alloquia, amicabilitas, et exhibita beneuolentia aliquid simile uiderentur testare; uerum / hoc satius reiicitur. /

[10] Independenter a relatione aliorum, in Deo intelligit uictorias et prosperitatem/ Regis Galliae uarie agitur, ut pro illo oret gratias agat etc. /

Etiamsi nullus mihi quidquam diceret de uictoriis, quas reportat Rex Galliae in Hollandia, non ideo / minus scirem; nam habeo de illis quasi spiritualem Echo, et certam cognitionem, quod faciat progressus, et / habeat uictorias, eo quod 
... truly I was to ... abstracted, and without imaginations of all things that are outside of God. I saw nothing, thought nothing ... for which the spirit prayed, was the King of France, for the help and assistance ... of him in his ... of leading Holland back to the catholic faith. Of this case the spirit had ... than ... as if without a body or an image, representation or a thought ... that ... this doesn't cooperate and therefore she has no corporeal ... nor represents ... image of that King or of some other thing. But the passive intellect ... contemplating and at the same time that passive intellect saw that the spirit ... in God, in nakedness of thoughts or imaginations or ... with thoughts ... I cannot ... explain. ${ }^{71}$

411

I saw and perceived that that prayer had great effects and by its power many graces flowed to that King, along with divine help and divine cooperation in carrying out his plan and intention. Clearly I understood that God wanted to grant him those graces and provide him the divine help and by such prayer and not otherwise cooperate with the intention of the King and that God for this purpose took and chose some small and humble and at the same time pure and sincerely God-loving women, to pray for them, and among these few His Majesty seemed to want to use me unworthy as I am. But to dare to say that the Beloved only wanted to use my work or prayer alone to this end, it seemed to me an intolerable presumption, although the internal conversation with the Beloved, the friendliness and the demonstrated benevolence seemed to prove something similar. But this should better be rejected.

Independent of the accounts of others she understands in God the victories and prosperity of the King of France. She is led to pray for him, to give thanks etc.

Even if no one had said anything to me about the victories, that the King of France achieves in Holland, then I would not have known it any less. For I have about them as it were a spiritual Echo and a certain awareness, that he makes progress and has victories, because I see in the spirit and feel that God is with him and because the Beloved brings me certainty about them in some spiritual

$71 \quad$ Here she speaks about the intellectual prayer which is without her own thoughts, images etc. and yet from the other side, i.e. from the side of the Beloved she receives the prayer for the French King, so it is a passive kind of prayer. 
uideam in spiritu, et sentiam quod Deus sit cum illo, et quia Dilectus spirituali / [15] quodam et intimo modo me de illis reddat certiorem; sicuti dicente Apostolo, ipse spiritus testimonum / reddit spiritui nostro quod sumus filii Dei, sic etiam diuinus spiritus testimonium perhibet spiritui meo / quod ille Rex prosperetur et uictorias reportet de inimicis suis. /

Aliquando etiam aliquod diuinum lumen in spiritu resplendens me excitat ad orandum, uel ad ......um / actionem, ut Deum de illa prosperitate et successu armorum, laudem, benedicam et glorific....... / [20] ut Regem Deo commendem. /

Duobus uel tribus diebus, postquam dictus sciendi modus in me fuisset, Dilectus mihi con.... / unum alium, uti mihi uidetur, sicuti antehac descripsi, et Reuerentiae Vestrae tradidi, de aliqua uisione in spiritu. /

Conatur explicare quomodo dicta oratio pure fiat in $\mathrm{sp}[\mathrm{iritu}]$..... spiritus / Dei ipsi unitus orat, et Deus se ipsum uidet, et amat et .... anima facit / [25] per gratiam quod Deus facit ex natura./

Procul digressa sum ab eo quod caeperam dicere, n. quomodo iam sit spiritus orandi diuersus a praecen- / denti, nempe quomodo haec oratio fiat omnino in spiritu, sine illa cooperatione potentiarum inferiorum / et sensitiuarum, etiam sine perceptione illarum; nam in praedicto aspectu Dei anima est abstracta a se ipsa / et est pure spiritus unitus diuino spiritui. /

[30] Est mirabile et uix intelligibile, quomodo dicam me esse unum in Deo, et quomodo in hac unio[ne] / Deum uideam; nam nostro modo loquendi, cum eo quod uidemus non sumus unum; est aliquid aliud <quod > / uidemus, et aliquid aliud quocum sumus unum; nam unum est unum, et aspicere sonat....... / et illud quod aspicitur; uerum .... aliter se rei habet in hac contemplatione...... / spiritus de qua loquor. /

[35] Hoc momento mihi indicit quomodo id sit, et quomodo id possim explic[are] ....... / piciat se ipsum cognoscat se ipsum, ac complaceat sibi ipsi diligat se $\mathrm{ipsu}[\mathrm{m}]$....... / essentialissime secum et in se ipso unitus et unus est, sic etiam ........ /

Anima facta unus spiritus cum Deo ............ / est unum esse, unum operari, intelligere ....... //

41v

[1] Eodem modo Deus dat animae per gratiam id quod ipse est per naturam, quam diu n. haec unio durat, / ipsa est unus spiritus cum Deo, unum operari, 
and intimate way. Like the Apostle said: "The spirit itself bears witness to our spirit, that we are sons of God."72 So also the divine spirit bears witness to my spirit, that King prospers and obtains victories over his enemies.

Sometimes also some divine light shining in the spirit excites me to pray or to ... action, so that I praise, bless and glorify God for that prosperity and success with weapons ... so that I entrust them to the care of God.

Two or three days after the aforementioned way of praying had been in me, the Beloved ... me some or other, as it seems to me, like I have described before, and have reported to Your Reverence, about some vision in the spirit.

She tries to explain how the aforementioned prayer happens purely in the spirit ... the spirit of God united with her prays and God sees himself and loves and... the soul does by grace what God does by nature.

I have far departed from what I began to say, that is how different this spirit of praying is from the previous, yes how this prayer happens totally in the spirit, without that cooperation of inferior powers and senses, also without the perception of them. For in this sight of God that has been mentioned the soul is abstracted from itself and is purely spirit united with the divine spirit.

It is amazing and hardly intelligible how I can say that I am one in God and how in the union I see God. For in our way of speaking we are not one with what we see. What we see and what we are one with are different. For one is one, and beholding sounds ... and what is beheld. But ... different ... has in this contemplation.... the spirit about which I speak. ${ }^{73}$

This moment he shows me how this is and how I might explain this ... knows himself and pleases himself and loves himself ... very essentially with him and in himself is united and one, also ...

The soul is made one spirit with God ... is one being and one operating, understanding ...

$41 \mathrm{~V}$

In the same way God gives to the soul by grace what He is by nature, as long as this union lasts. It is one spirit with God, one operating, one understanding,

$72 \quad$ Rom. 8,16.

73 Clearly language here cannot express exactly the union with God that Maria Petyt has experienced. 
unum intelligere, unum uelle, unum diligere / ipsa non nouit differentiam uel distantionem inter ego et meum, omnia plane unum sunt et in uno quae- / cumque cognoscit uel intelligit. /

[5] Quocirca quando ipsa orat, est spiritus Dei qui orat in illa; quando ipsa contemplatur et diligit Deum / est Deus qui se ipsum in illa contemplatur et diligit. /

Hic status unionis in se comprehendit bene aliam puritatem, simplicitatem, intimitatem, et sublimitatem / spiritus, quam praecedens; quando enim tunc spiritus amoris operabatur et dirigebat meas animae potentias / tunc multum cooperabar, licet acta et directa per gratiam, et per ignem amoris; tunc etiam magis perci- / [10] piebam me ipsam, uel aliqua alia, licet tamen in Deo; sed non eram sic plane unum cum Deo, sicut modo / habebam cooperationem simul cum gratia seu spiritu Dei; at iam uideor totaliter esse unum cum Deo, et in / ipsum mutata, spiritus Dei hic fere facit omnia ipsum; sine gustare sine experiri, et sine distinctione, / potentiarum inferiorum et superiorum. /

Quidquid in Deo aspicio, gusto, experior, percipio, id totum est absorptum in unitate diuinae essentiae ipsi... / [15] in hoc statu nullo modo sum idonea ad externam locutionem uel occupationem, sed anima mea tendit ad / summum tranquillitatem, omnes meae potentiae sunt arrestatae et suspensae in Deo, et attractae in sublimi- / tate sp[irit] us, existentes ibi in suo centro, quamdiu hic tractus, seu status unionis durat; quidquid est / extr.... centrum, est mihi taediosum et causat nauseam. /

Dicta oratio diuini spiritus fit sine uerbis, sine instantiis, per aspectum ad Deum / [20] haec oratio est efficacior altera, utraque tamen a Deo datur; neutra est in / hominis potestate. /

Quando hic spiritus orationis in me operatur, tunc haec oratio non fit loquendo, uel per uerba nec / cum blandis instan[tiis] pressionibus etc. sed solummodo, cum uno intuitu ad Deum, et cum ardente amoris / affectu; qui tam su<aui>ter et intime in anima operatur, ut ipsamet uix percipiat; eo quod eius intuitus et / [25] tota attentio sit, adeo arrestata, et fixa in Deo: hoc diligere, hoc aspicere ad Deum, siue hic intuitus, haec / [d]ilectio Dei, notificant Deo, quid ipsa desideret, et postulet, u.g. prosperitatem faelicem progressum / armorum Regis Galliae contra Haereticos in Hollandia, anima scit et intelligit hoc sic esse, ideo in / hoc tranquillo intuitu anima multo plus facit, quam si formaret expressa uerba; nam mihi / uel unus nutus sufficit. /

[30] E[xper]ior quod spiritus multo efficacius oret in hoc tranquillo et amoroso aspectu Dei, quam cum multis / <bla>ndis supplicationibus et 
one wanting, one loving. It does not know any difference or distance between I and my, all is clearly one and in that one it knows and understands all.

Therefore when the soul prays it is the spirit of God that prays in it. When it contemplates and loves God, it is God who contemplates and loves himself in the soul.

This state of union comprehends in itself well another purity, simplicity, intimacy and loftiness of the spirit, more than the previous. For when the spirit of love operated and directed the powers of my soul then I cooperated much, although I was led and directed by grace and by the fire of love. Then also I perceived myself more, or something else, although still in God. But I was not so clearly one with God, as if I had now a cooperation at the same time with grace and with the spirit of God. And already I seemed to be totally one with God and changed into Him. The spirit of God now made almost everything Him. Without tasting, without experiencing and without the distinction between inferior and superior powers.

Whatever I behold in God, and taste, experience, perceive, that is totally absorbed in the unity with the divine essence itself ... in this state I am in no way capable of any speaking or occupation outside of Him, but my soul tends to the highest tranquillity, all my powers are resting and residing in God, and are attracted to the sublimity of the spirit, being there in his centre, for as long as this attraction or state of union lasts. Whatever is outside ... the centre is for me disgusting and causes nausea.

The mentioned prayer of the divine spirit happens without words, without intercessions, but through the sight at God. This prayer is more effective than other prayer, although both are given by God. None of them is within human power.

When this spirit of prayer operates in me, then this prayer does not happen in speaking or by words or with sweet intercessions and pressure etc, but only with one beholding of God, and with a burning feeling of love. That operates so sweetly and intimately in my soul, that the soul itself hardly perceives it, because its gaze and total attention is so much held and fixed in God. This loving, this beholding of God, or this look, this love of God, notifies to God, what the soul desires and begs, e.g. prosperity, a happy progress of weapons for the King of France against the heretics in Holland. The soul knows and understands that this is so, therefore in this peaceful sight the soul does much more than if it had formed expressed words. Because for me one gesture is sufficient.

I experience that the spirit prays much more forcefully in this quiet and loving sight of God, than with many sweet prayers and intercessions ... still the 
instantiis ..tamen siue unum, siue aliud neuter modus orandi est in mea / .um uel alium meum uiri...... possum assequi, uel causare etiamsi ad id adhiberem omnem / sed ambo debent mihi concedi utrumque operari spiritus Dei siue eius / ferentur accommodare / [35] loco quando mihi gratiose eo difsiue uno siue alio modo cum sancta libertate / quendo spiritus et illi locum dando

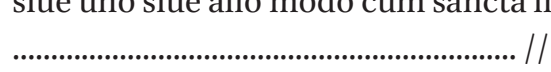
us operari dignatur. /

$42 r$

[1] Redit iterum spiritus orandi in fauorem Regis Galliae, in spiritu / per spiritum, ante faciem Dei, essentiali modo notificand[o] Deo / sua desideria etc. /

Die 21 Nouembris 1672 , post sacram communionem rediebat spiritus orandi pro / [5] prosperitate armorum Regis Galliae, quando spiritus eleuatur ad contem- / plationem Dei, communiter mihi aduenit spiritus orandi, modo iam saepius dicto, / aliquando diu durat, aliquando tantum ad unum miserere, uel circiter; potest / nominari spiritus passiuae orationis, quae solummodo fit in spiritu, per spiritum in / magna sublimitate et distantia ab omnibus his inferioribus. /

[10] In hoc modo orandi numquam sunt cogitationes, uerba, imaginationes, spe- / cies aut formae aliquarum rerum, quas eloqui possumus; spiritus orat non / formando cogitationes; quantum possum assequi, quando spiritus sic stat ante / diuinam faciem, et orat, tunc omnes instantiae, desideria, appressiones, affectiones, / et cognitiones animarum, pro quibus orat, sunt occulte conclusae, et impercep- / [15] tibiliter operantur in, et per istum aspectum spiritus Deum intuentis, per / quem aspectum anima essentiali modo Deo notificat sua desideria, et Deus / illam intelligit sine cogitationibus, uerbis, uel imaginationibus circa illa, pro / quibus orat; quia spiritus tunc stat apertus ante Deum uelut clarum spe- / culum, et etiam omnia, quae Deus actualiter operatur in spiritu, sc. istam / [20] orationem, quae omnia sunt Deo nota, quia actualiter fluunt ex Deo in ani- / mam, et iterum refluunt ex anima in ipsum. /

Tunc tantum est unus simplex intuitus animae, seu spiritus ad Deum, et secreta / seu tacita notificatio suorum desideriorum; quod fit cum tanta tranquillitate / et abstractione in spiritu per spiritum, ut ipsamet uix sciat uel 
one or the other, neither way of praying is in my ... or my other ... I can follow or cause even if thereto I applied all ... but both must be granted to me, each of both ... operate the spirit of God or his ... place when to me graciously ... differ to accommodate ... the spirit and giving place to it in one or other way with holy liberty ... deems worthy to operate. ${ }^{74}$

\section{$42 r$}

Again ${ }^{75}$ the spirit of praying returns in favour of the King of France, in the spirit, through the spirit, before the countenance of God, in an essential way notifying God of his desires.

On the 21th of November 1672 after holy communion the spirit of praying for the prosperity of arms of the King of France returned, when the spirit was elevated to the contemplation of God. In general the spirit of praying comes to me in a way that I have mentioned more often, sometimes lasting for a long time, sometimes only as long as one Miserere or thereabout. This can be called the spirit of passive prayer, that happens only in the spirit and through the spirit in a greatly sublime way and distance from all these inferior powers.

In this way of prayer there are never thoughts, words, images, sights or forms of things, that we can describe. The spirit prays while not forming thoughts. As far as I can fathom, when the spirit stands like that before the divine countenance and prays, then all intercessions, desires, pressures, feelings and thoughts of the souls, for whom he prays, are included in a hidden way and work imperceptibly in and through that sight of the spirit that is finding God, through which sight the soul notifies God in a essential way of its desires. God understands it without thoughts, words or images concerning that for which it prays. Because the spirit stands then open before God like a clear mirror and also all that God at the moment operates in the spirit, namely that prayer, all of that is known to God, because it flows at the same moment from God into the soul and reflows again from the soul into Him.

Then there is only one simple movement of the soul or of the spirit to God and a secret or silent notification of its desires. That happens with such tranquillity and abstraction in the spirit and through the spirit, that the soul self

74 Two ways of praying are discussed here, both of which are passive kinds of the prayer. The prayer that she describes here which is without words, intercessions etc seems to be a kind of prayer from the state of a unio mystica.

Here begins the third part of the document. It follows on fol. 33 . 
postea .....niscatur; / [25] hoc intelligit anima esse, adorare Deum in spiritu et ueritate si.......ebus, / imaginationibus, aut formis. /

Dicto modo dicit intelligi dum dicit se aliqua in.....dere / intelligere etc, sc. ista fieri sine uerbis, sine speci[ebus] corporeis; / uidet creaturas in Deo ut unitas diuinae essentiae. /

[30] Hoc modo debet Reuerentia Vestra intelligere multas differentes inoperationes, quando / facio mentionem, quod aliquas alias operationes uideam in Deo, intelligam / in Deo alicuius rei in Deo meminerim uel aliquas alias operationes spiritus, / siue orare, siue aliquid aliud praecipue istud orare tempore unionis, siue / sublimis contemplationis, nimirum, quod similia semper fi.... sine imaginatio-/ [35] nibus, sine uerbis, sine cogitationibus, sine ullis specieb[us] ....um corporearum / quia nullae cogitationes; aut species corporeae etc. pe.... spirit...... / nam spiritus ea uidet, ea comprehendit solummodo in ...... / ueritate, et unitate, quae Deus est; omnia autem quae in Deo ...... / telliguntur, cognoscuntur, sunt Deus in Deo, quia in Deo ni........ / [40] et quamuis ibi sit aliqua reminiscentia aut cognitio alicuius ........ / Deo, non uidetur, nec cognoscitur ut creatura, sed ut unita .... / in diuina essentia, et ut unum cum illa. /

Quidem uerum est, quando Deus aliquid manifestat ........ /

Galliae, eius intentum, eius exercitum, eius progressum ...... /

[45] absoluta indistinctio, quam in sola simplici, informi eius / ...icio; est aliqua distincta indistinctio in ill.... que a...... //

$42 \mathrm{~V}$

[1] cognoscuntur conclusa et unita in informi unitate diuinae essentiae; ideo nullae ima- / ginationes possunt incidere in intellectum, ut aliquid distincte de illis dicamus, / uel formemus; solummodo retineo obscuram cognitionem et confusam memori- / am aliquorum, quae Reuerentiae Vestrae scripto explico, quam optime possum. /

[5] Haec reuera bene potest uocari oratio passiua, ad quam de nostro nihil possumus / addere, ut illam assequamur, uel ut diutius continuemus; nihil ibi de meo est inter- / mixtum, nec potest intermisceri; quando uero aliquid de meo accedit, et si tan- / tum simplex aduertentia, uel reflexio ad illam, ilico intermittitur, uel minuitur / ista inoperatio, et anima deorsum demittitur in se ipsam. /

[10] Aliud est, quando spiritus amoris orat, et confidenter agit cum Dilecto / tunc enim miscetur aliquid plus de meo, ibi tolerantur actus fidei, spei, 
hardly knows or afterwards ... understands that this is: to adore God in spirit and in truth without ... images or forms.

In this way she says to be understood, while she says that she some ... understands etc, namely that this happens without words, without corporeal images. She sees creatures in God as a unity of the divine essence.

In this way Your Reverence must understand the many different operations, when I make mention of some other operations that I see in God, and understand in God and remember something in God or some other operations of the spirit whether praying or something different, in particular this praying in a time of union, or of extraordinary contemplation, certainly that similar things always happen ... without images, without words, without thoughts, without any sights of corporeal ..., because no thoughts or corporeal sights etc ... the spirit ... for the spirit sees them, comprehends them only in ... truth and unity, which is God. But all that in God ... is understood, known, is God in God, because in God ... and although there is some reminiscence or thought of some ... God, is not seen and not known as a creature, but as united ... in divine essence, and as one with it.

It is certainly true, when God manifests something ... of France, his intention, his army, his progress ... absolute confusion, how in only simple, unformed ... of him ... ... there is some distinguished confusion in that ...

\section{V}

They are known concluded and united in an unformed unity with the divine essence. Therefore no images can end up in the intellect, so that we might say or form something distinct about them. I only keep an obscure thought and a confused memory of some things, that I explain to Your Reverence in my writing, as well as I can.

Indeed this might well be called a passive prayer, to which we cannot add anything of ourselves to attain it or to continue it any longer. Nothing of myself is intermingled in it, nor can it be intermingled. But when something of myself approached, even if it were just a simple turn or reaction to it, then suddenly this operation would be interrupted or diminished and the soul would be thrown back down on itself.

It is different when the spirit of love prays and speaks confidently with the Beloved, for then something is mixed of myself, and there acts of faith are 
chari- / tatis etc, ac cogitationes et imaginationes secundum exigentiam istius / orationis et cum Dilecto conuersationis: attamen etiam sic omnia diriguntur, / et proueniunt ab influxu diuinae gratiae, cui anima tunc respondet, quam inse- / [15] quitur, et quacum simul operatur, secundum quod tractus, motio et influxus / gratiae uidetur manuducere, et dirigere. /

Docetur spiritum amoris sequi modo simpliciori, quasi uno / nutu uel ictu oculi ad Dilectum, ad Angelos cum sola / ultronea ebullitione amoris. /

[20] Dixi antecedenter, quod uiderer instructa, quod spiritum amoris parcius / sequi debeam; nunc doceor, quomodo liberius eum insequi liceat praesertim / extra orationem, sed modo tranquilliori, nobiliori et spiritualiori, nempe sine / multis discursibus, aut expressis multiplicibus uerbis, aut alloquiis ad Dilec- / tum ... ad sanctos Angelos, sed solummodo per tranquillam ebullitionem / [25] teneri ... [s]uauis amoris, quasi uno nutu, aut amoroso oculo ad Dilectum, / ei propo...do, et notificando id quod spiritus amoris dictat, u.g. de auxilio, / de protectione etc concedenda Regi Galliae, uel exercitui illius, de donis gra- / tiarum impertiendis animabus conuertendis etc. /

Operationes et accessus amoris interius ultro ebullientes ad hoc, uel illud / [30] in Deo dilectum etc, tantum debent fieri ....asi cum breuibus excursibus / spiritus, non se ulterius uel uiuacius extendo uel dispergendo extra limites / simplicitatis: ignis amoris bene potest scintillare in corde, imo etiam flam- / mare, sed totum cum tranquillitate, quasi quiescendo, et euanescendo in / fundo: unde h...ndo aliqua uerba amoris, suaues affectus, uel etiam aliquis / [35] zelus ad ....ore.. Dilecti, uel salutem animarum ebulliunt, oportet illa it / .......uiuaciter actiue ab .qu.. reflexione, uel aliqua stabili de illis / .......e, ac sine additione aliqua ex parte nostra. /

....ur habere unionem cum intellectu diuino in quo uidet /

......a, quae scripta combusserat, ut iterum scribat: uitem /

[40] ....ilecti, ut zelet eius gloriam. /

.ris 1672, euigilans, et postea iterum in oratione, uidebar /

......unionem cum intellectu diuino; per quam multa, quae / erum et combusseram (uti Reuerentia Vestra scit) iterum renoua- / abantur, et uiuaciter in memoriam reducebantur // 
tolerated and of hope, love etc. and thoughts and images according to the requirements of this prayer and of the conversation with the Beloved. Nevertheless also in this way all is led by and stems from the influence of divine grace, to which the soul then responds, which it follows and with which it operates at the same time according to which the need, the movement and the influence of grace seem to guide and to direct.

She is taught to follow the spirit of love in a more simple way, as with a wink or a nod to the Beloved, to the angels with only a voluntary outburst of love.

I have said before, that I seemed to be instructed that I had to follow the spirit of love more sparingly. Now I was taught how it is permitted to pursue it more freely especially outside of prayer, but in a more quiet, noble and spiritual way, yes even without many dispersions or many expressed words or talking to the Beloved ... to the holy angels, but only by the quiet simmering of a tender ... sweet love, like with one wink or with a loving eye to the Beloved, to him ... and noting what the spirit of love dictates, e.g. about the help, the protection etc, which should be provided to the King of France or to his army, about the gifts of grace which are granted to the souls which should be converted etc.

The operations and tendencies of love which spontaneously boil up inside or what is loved in God, just have to happen ... with short digressions of the spirit, not extending or spreading out further or more vividly outside the limits of simplicity. The fire of love may well sparkle in the heart, yes even flame, but all with quietness, like resting and vanishing into the depths. Hence ... some words of love, sweet feelings or even some zeal to ... of the Beloved, or the salvation of the souls boil up, it should be that it ... vividly, actively, without reflexion or some stable ... about them, and without any addition from our side.

... to have union with the divine intellect in which she sees

... which writings she had burnt, like she wrote again: ...

... of the Beloved, so that she strives for his glory.

... 1672, waking up, and then again in prayer, I seemed

... union with the divine intellect. By that many, that

... and I had burned (as Your Reverence knows) again renewed

... and vividly were brought back to memory. 
[1] demonstratione, et suasione, ut rursus exscriberem, (sed id adhuc parum differo, / donec spiritus me magis urgeat). /

Item mihi significabatur, quod Rex Galliae occupabat Hollandiam; hoc mihi / uidebatur omnino certum: Item certificabar, omnes operationes, quas spiritus / [5] amoris ab octo uel nouem mensibus et postea in me, et per me operatus est / quoad Hollandiam, fuerint diuinae; qui spiritus iterum resumit suas opera- / tiones, sicut tunc; et sentiebam me quasi fuissem charissima consors Dilecti / mei, tota zelosa pro augenda gloria eius, in lucro animarum cordi habendo, / primo eas perducendo ad ueram fidem, deinde ipsis prouidendo de omnibus / [10] gratiis ad salutem necessariis et utilibus. /

Eodem die ante et post sacram communionem incipiebat spiritus amoris, et / spiritus orationis me ualde efficaciter inuadere, qui mihi uidebatur quasi uim / inferre, et mihi uelle praeualere, sed me statim accommodabam, et sequebar, / quo ipse me impellebat, et ubi erat impetus illius, illuc gradiebar; uidebar/ [15] interius intelligere; sponsa mea non semper est tempus quiescendi, me in / tranquillitate fruendi, et dormiendi somnum amoris; sed in illis etiam, quae / mei honoris et gloriae sunt, oportet te esse, et occupari; euigila et surge, et dis- / pone te ad operandum. /

Statim eram parata, sed intelligebam, quod Dilectus me non uellet extra- $/$ [20] here ex mea solitudine; quia illa mihi est omnino necessaria ad diuinum / eius propositum et intentum; sed solummodo uolebat, ut darem locum spi- / ritui amoris; et ecce statim omnes meae potentiae inferiores uidebantur se / insolito quodam diuino modo aperire, et expandere, ut quasi apprehenderent / et haurirent spiritum diuinum, eique locum praeberent, qui spiritu[s]... [in]cipiebat / [25] in me operari hoc modo; spiritus uidebatur quasi circumplecti .... christi- / anismum rara dilectione, et praetenero affectu, ad salutem ....., quos / Deus praelegit ad salutem; pro ut alibi fusius praeduxi. /

Renouatur in illa tener affectus erga Regem Galliae ut a / Deo et in Deo dilectum, et instanter pro eo orat; unde putat / [30] eum non esse tam malum, uti multi eum reputant. /

Quando spiritus amoris sic in me operatur, tunc renouatur in me iste tener / amoris affectus, et sensibiliter spiritualis inclinatio erga Regem Galliae, uti / antehac, uelut erga aliquem a Deo et in Deo Dilectum [imp]etus spiritus, quo / 
(...) the demonstration and persuasion, to go back to writing (but I postpone that still a bit, until the spirit urges me more).

Likewise it was signified to me, that the King of France occupied Holland. That seemed to me completely certain. Likewise I was assured that all the operations, which the spirit of love had operated in me since eight or nine months ago, and afterwards had operated in me and through me with regard to Holland, had been divine. That spirit resumed again his operations like then. And I felt myself like I was the most beloved companion of my Beloved, totally zealous to increase his glory, and to have the profit of souls at heart, first by leading them to the true faith, then by providing them with all graces that are necessary and useful for salvation.

The same day before and after holy communion the spirit of love and the spirit of prayer began to invade me very forcefully, that seemed as if to bring me strength and to want to prevail upon me, but I suddenly conformed and followed, where he urged me and where his attack was, there I went. I seemed to understand inside: "My bride, it is not always time to rest, to enjoy me in quietness and sleep the sleep of love. But also in those things, that are to my honour and glory, there you should be and be occupied. Be vigilant and arise, and prepare yourself for work."

Immediately I was ready, but I understood, that the Beloved did not want to extract me from my solitude. Because that is for me entirely a necessity for his divine plan and intention. But He only wanted that I give place to the spirit of love. And see, at once all my inferior powers seemed to open themselves in an unusual somewhat divine way, ${ }^{76}$ and to spread out, so that they would apprehend and take in the divine spirit, and give place to it. That spirit ... began to operate in me in this way. The spirit seemed as it were to embrace ... Christianity with a strange love and very tender affection, to the salvation ... whom God has elected for salvation, as I have suggested elsewhere.

In her a tender affection towards the King of France is renewed as if loved by God and in God, and instantly she prays for him. Hence she believes that he is not as bad as many regard him to be.

When the spirit of love operates so in me, then that tender feeling of love is renewed in me, and sensibly I can feel a spiritual inclination towards the King of France, like before, as towards someone who is beloved by God and in God.

76 See n. 15 . 
erga eum feror, est magnus et rarus, quia ex natura .... non sum inclinata / [35] erga homines, nec sum amatiua hominum (uti Reuerntia [Vestra] .... motio- / nem gratiae; sentio me quasi tutam pro ipso, n. in eius fauorem ..... / Instantiae, et amorosae postulationes, quas spiritus facit pro ips..... / Dilectum, apud Matrem amabilem, et sanctos Angelos, sunt millae et ..... / quae omnes a spiritu amoris dictantur et pronuntiantur per int..... / [40] ebullitiones amoris. /

Haec in me deprehendens non possum credere mala, quae de isto Rege .... / guntur; ab aliquot diebus ueniebat me aliquis inuisum, qui hunc .... / depingebat tam turpiter, quasi fuisset notorius scurra et nebul........ / multum uulnerabat, et eum totis uiribus defendebam; quia ........ / [45] apparet in animo meo, quam homines ipsum diiudicant; . $/ 1$

$43 \mathrm{~V}$

[1] nequam, et tam impius, ac peruersus traducitur, non possem eum adeo / in Deo diligere, nec essem adeo stabiliter bene ad illum inclinata; secun- / dum naturam non habeo ad hoc ullam rationem, aut motiuum, sed potius / econtrario. haec scripsit 9 Decembris $1672 . /$

[5] Propter dicta de mala Regis uita conatur se ab illo auertere / sed in oratione discit plane contrarium, cum inclinatione ad / illum, et certitudine, quod Deo placeat; et erit uictoriosus / orat pro illo contra aduersarios illius. /

Quia praedicta persona tam multa mihi referebat ad confirmationem, quod / 10 dictus Rex esset nequissimae et perditae uitae, et ideo omni benedictione in- / dignus, adeoque merito Deo sic disponente, perdidisset conflictum, et habu- / isset cladem magnam, in punitionem praeteritae suae, et adhuc, ut dicebat / praesentis scandalosae uitae; idcirco conabar me ab isto Rege alienare, omnem / affectum abstrahere, spiritum pro ipso orandi repellere, omnem meam inte- / [15] riorem experientiam, et testificationem abiicere, et diffiteri; uelut meram / fraudem et deceptionem, non sine sensu praemagnae afflictionis, et interna / praessura. /

Uerum cum me dedissem orationi, Dilectus me iterum faciebat sentire / et intelligere plane contrarium, cum tali interna certificatione ueritatis, / [20] cum tali confortatione, cum tali illecebra, amore et beneuolo affectu / 
The force of the spirit, by which I am brought towards him, is great and strange, because by nature ... I am not inclined towards men, and I am not a lover of men (like Your Reverence ...) ... movement of grace. I feel like I am being saved for him, for in his favour ... Intercessions and loving prayers, which the spirit does for him... the Beloved, in the presence of his loving Mother, and the holy angels are thousand and ... that all are dictated by the spirit of love and are pronounced by ... simmering of love.

Discovering these things in me I cannot believe the bad things that are ... about that King. Since some days ago someone came to me unseen, who ... depicted him so shamefully, as if he was a notorious criminal and ... wounded him much and I defended him with all my strengths. Because ... appears in my mind, like men judge him ...

$43 \mathrm{v}$

... wicked, and so impious and perverse is transferred, I could not love him so much in God, and I would not be so stably well inclined to him. According to nature I have no reason or motive for this, but rather the contrary. These things she wrote on 9 December 1672.

Because of the things that are told about the bad life of the King she tries to turn away from him, but in prayer she learns clearly the contrary, with the inclination to him and the certainty that he pleases God, and that he will be victorious. She prays for him against his opponents.

Because the afore-mentioned person told me so much as confirmation, that the King of whom I am speaking had a very wicked and corrupted life, and therefore was unworthy of all blessing, and as God had disposed with good reason he had lost the conflict and had suffered a great defeat as punishment of his former and, as it is said, still presently scandalous life. Therefore I tried to alienate myself from that King, and to withdraw all affection and to repel the spirit of praying for him, and to reject and deny all my inner experience and proof. As if it were mere fraud and deception, not without the feeling of great affliction and internal pressure.

But when I had given myself to prayer, the Beloved made me feel again and understand clearly the opposite, with such an inner certainty of the truth, with such comfort, with such allurement, love and benevolent affection towards 
erga hunc Regem, ut pro illa ueritate bene uoluissem mori, quod ipse / esset a Deo dilectus, et quod haberet uictoriam in Hollandia; nam / zelus, et spiritus, qui mihi pro tunc de nouo iterum infundebatur, coö- / perab[atu]r simul cum spiritu Dei, ut exercitum haereticorum, et etiam nostr- / [25] um ex[ercitu]m, qui ipsis uenerat in subsidium, delerent, profligarent, ipsorum / robur et potentiam eneruarent etc. /

In dictis precibus a Gubernatore Patriae pro successu contra / Gallos ante Caroloregium, ipsa dicit omnes preces fore inefficaces / et unam exaudiendam contra omnes: uidet spiritum Dei ferri/ [30] super exercitum Gallorum. /

Hoc tempore quo Patriae Gubernator comes de montereii requisiuerat, / ut indicerentur preces communes, et omnis clerus, ac totius Patriae Reli- / giosi omnisque [p] opulus orarent ad optatum successum sui boni propositi, / et intenti (uti di[ce]bat) quod erat, ut cum omni suo exercitu coniunctis / [35] [c]opiis hae....... obsideret Caroloregium, et alias Ciuitates in fauorem / .........xis Auriaci; hoc ego audiens, eram prae zelo fere in interna motione / ........ae, et dicebam, subridendo intra me; orate uos omnes, orate, orate, quam / ......uultis, cum omni uestra oratione nihil obtinebitis; nam latet alicubi / ......humilis anima abscondita in angulo, quae a Deo accepit potestatem / [40] ........bendi omnes orationes tam multorum, et impediendi, ne a Deo ex- / audiantur, quia bene scit, quod exauditio istarum orationum tenderet, et / ........contra Dei honorem et gloriam, et contra promotionem Sanctae Eccle- / [siae]..... nes orant, nescientes, quid orent, n. qui suam intentionem for- $/$..... conformabant intentioni supradictae. /

[45] ........ parua et humilis anima erat illuminata et instructa de //

$44 \mathrm{r}$

[1] ueritate et orabat contrarium, quam alii, acta et impulsa per in- / stinctum et impetum spiritus sancti, et huius humilis et abiectae animae ora- / tio fuit exaudita contra omnes, prout postea ex effectu secuto patuit, / quando nostri 
this King, that I would have wanted to die for that truth, that he was loved by God and that he had the victory in Holland. For the zeal and the spirit, that was poured into me then anew, cooperated at the same time with the spirit of God, so that they would destroy and defeat the army of the heretics and also our army that had come to help them, and would weaken their strength and power etc.

In the prayers that have been mentioned by the Governor of this country for success against the French before Charleroi, ${ }^{77}$ she says that all prayers will be powerless and that one must be heard against all. She sees that the spirit of God is brought to rest over the army of the French.

In this time when the Governor of this country, the Count of Monterrey ${ }^{78}$ requested that common prayers be proclaimed and that all clergy of the country and all people would pray for the desired success of his good plan and intention (as he said), which was that he with the troops connected with all his army ... would occupy Charleroi and the other cities in favour ... of Auriacum. ${ }^{79}$ When I heard this I was moved internally by zeal ... and I said, smiling inside: "Pray all of you, pray, pray as much as you ... want, with all your prayers you will obtain nothing. For somewhere is hidden ... a humble soul lost in a corner, who receives from God the power to ... all prayers of so many, and to impede that they are heard by God, because He knows well, that the hearing of these prayers tends and ... against the honour and glory of God and against the promotion of the holy Church ... they pray, not knowing, what they are praying for, namely that his intention ... they conformed to the afore-mentioned intention."

... a small and humble soul was illuminated and instructed about ...

$44 \mathrm{r}$

the truth and prayed contrary to the others, led and driven by the incitement and insistence of the holy spirit, and the prayer of this humble and inconsiderable soul has been heard against all, as afterwards is proved by the effect that

$77 \quad$ See n. 16 .

78 Don Juan Domingo Mendez de Haro was married to the 6th Countess of Monterrey and used the titles of his wife for himself.

79 Auriacum is the Latin word for Orange. Perhaps Maria refers here to William III the stadtholder of Holland. 
milites, et haeretici prae inedia et miseria debuerunt rece- / [5] dere cum magno damno et infamia. /

Quid est mirum, quod Galli ita praeualeant et sint adeo uictoriosi in / Hollandia? Deus est cum illis; semel uidi in spiritu, quomodo spiritus Dei / ferebatur super exercitum Gallorum, sicut olim spiritus Dei ferebatur super aquas. /

Possessa a spiritu Jesu agitur zelo animarum, cui resistit ut / [10] suspecto, quia non sequitur exspectatus effectus in Hollandia / iuxta aliquorum relationem, quam a Dilecto intelligit esse / falsam. /

Uideor percipere, quod aliquando sim possessa a spiritu Jesu, qui in me / producit sitibunda desideria salutis animarum, qualia Jesus habuit, dum/ [15] uiueret, et adhuc iam in uita sua gloriosa, hic spiritus mihi heri die 16 / Decembris 1672, subito quasi infundebatur; cui sub initium nonnihil reluc- / tabar, quasi illum reprobando; cogitans ad quid seruiunt istae operationes spi- / ritus amoris? quid inde prouenit? solummodo habeo desideria, et affectus, sine / ulterioribus affectibus; prout patet quoad Regem Galliae in Hollandia, ubi / [20] spiritus amoris adeo continuo, et quidem tam singulari modo operatus / fuit cum apparente bono successu, et iam ista bona apparentia quasi inuertitur, / et omnia susque deque uertuntur, et totaliter intricantur. /

Sic mihi ab uno aut altero referebatur, quod uictoriae Regis Galliae tota- / liter inuerterentur, quod illi iterum aliquot Ciuitates in Hollandi[a ar]mata / [25] manu essent ereptae, sed fuerunt mendacia. /

Item quando noster exercitus simul cum haereticis Caroloregium obsidebat, et / mihi multa dicebantur de illorum uictoriis, quae erant falsa, et omnino contraria, / quia cum confusione prae inedia et miseria coacti sunt soluere obsidionem, et / recedere ad sua praesidia; ita ut passim potuerint aduertere, quod male- / [30] dictio Dei fuerit super illos. /

Item quando Reuerentia Vestra mihi scribebat Boxmera, quod ibi multum timeretur, / quod Galli succumberent, et caederentur, eo quod Hispani et Caesariani magnas / haereticis darent suppetias, ita ut humanitus loquendo, absque speciali Dei assistentia/ Galli undique expellerentur, et haeretici praeualerent, quo .... negocium Religi- / [35] onis ibi ualde male cederet, Religiosi, et Catholici eii...... omnes hae/ apparentiae faciebant me multum 
followed, when our soldiers and the heretics, because of starvation and misery, had to withdraw, with great damage and disgrace.

No wonder that the French prevail, and have so much victory in Holland! God is with them. Once I saw in the spirit how the spirit of God was brought to rest over the army of the French like once the spirit of God was brought to rest over the waters. ${ }^{80}$

Possessed by the spirit of Jesus she is animated by zeal for souls, to which she resists as to a suspect kind of zeal, because the expected effect in Holland doesn't follow according to the story of some. But of the Beloved she understands that these stories are false.

I seem to perceive, that sometimes I am possessed by the spirit of Jesus, who produces in me thirsty desires for the salvation of souls, such as Jesus had while He lived, and still now has in his glorious life. This spirit was suddenly as it were poured into me yesterday on the 16 th of December 1672 . To which I resisted from the beginning somewhat, as if I rejected it, thinking: to what purpose do those operations of the spirit of love serve? What comes forth from it? I only have desires and feelings, without further feelings. Like it appears in regard to the King of France in Holland, where the spirit of love has operated in such a continuous and even such a particular way with apparent success, and yet that good appearance is sort of inverted and all is turned upside down and is totally confused.

This way it was told to me by the one or the other, that the victories of the King of France are totally inverted, that some cities in Holland were recaptured with an armed force, but those stories were lies.

Likewise when our army together with the heretics occupied Charleroi many things were said to me about their victories, which were false, and entirely the opposite, because with the confusion in the face of starvation and misery they were forced to renounce the occupation and withdraw to their garrisons, so that they could observe everywhere that the curse of God would be over them.

Even so when Your Reverence wrote me from Boxmeer, that there was great fear that the French would succumb and fall, because the Spaniards and the Imperials gave great support to the heretics, so that humanly speaking, without the special assistance of God, the French would be expelled from everywhere and the heretics would overpower them, ... the case of religion would yield there very badly, the Religious and Catholics ... all these appearances

$80 \quad$ Vg. Gen. 1,1. 
diffidere de ueritate illorum, qui mihi / interius uidebantur reuelata, pro aliquo tempore, donec Dilectus mih[i].... / de istis daret confirmationem. /

Deus sibi complacet in operationibus spiritus amoris, et illas / [40] remunerat, etsi effectus sperati non sequantur; quod etiam sanc.. / Gertrudi reuelatum est. /

Dum haesitarem in praedicta ambiguitate, et differentia de bono spiritu pro ..... / cessus expectationi meae contrarios, uidebatur mihi interius responderi .... / ficari, permitte amorem operari, da illi plenam agendi libertatem, non .... / [45] iendo, an aliqui effectus, seu fructus sequantur, nec ne; istae operationes ....//

$44 \mathrm{~V}$

[1] mihi complacent, sunt mihi pergratae, et tibi meritoriae, ac fructiferae, eodem / modo, acsi omnes illas animas de facto mihi lucrata fuisses, et ad me reduxisses. / Ex quo sequebatur ulterior cognitio, quod Dilectus illos affectus, et fer- / uentia desideria uellet remunerare, uelut facta, etiamsi effectus non semper, / [5] nec in omnibus sequatur; sicuti Concionatores, Confessarii, et alii operarii in / uinea sanctae Ecclesiae, non frustrantur meritis, et mercede laborum suorum, / quos exentlant ad lucrandas animas, etiamsi de facto paucas Deo lucren- / tur; dummodo tantum faciant, quantum in se est, operando et laborando cum / sincera, et pura ad Deum intentione, cum zeloso conatu, solummodo acti di- / [10] recti, et impulsi motiuo charitatis Dei et proximi ibi, enim sic procedendo habeat / plenam mercedem suae perfectae uoluntatis et dilectionis: hoc ualde clare in- / telligebam cum magna assecuratione et certificatione ueritatis. /

Ad maiorem certificationem mihi etiam reducebatur in mentem id, quod / Dilectus semel respondebat S. Gertrudi in simili casu suam querimoniam/ [15] ipsi deponenti, quod non semper uideret actuales fructus sequentes ex huius- / modi zelosis desideriis, feruentibus amoris affectibus, et similibus amorosis / operationibus spiritus amoris, quo subinde agebatur; ipsi enim interius dice- / batur; etiamsi ex illis non uidear desideratos pullulare fructus, mihi in / illis complaceo, et meam inde haurio iucunditatem, uidendo sic ista bona / [20] desideria, et motiones amoris operari. / 
made me doubt much about the truth of those things, that seemed to be revealed to me inside, for some time, until the Beloved gave confirmation about those things.

God is pleased with the operations of the spirit of love, and He rewards them, even though the desired effects do not follow. All this is also revealed to the holy Gertrudis. ${ }^{81}$

While I hesitated in the aforementioned ambiguity and doubt about the good spirit for ... contrary to my expectations, it seemed that I was answered inside ... permit love to operate, give it full freedom to act, not ..., or some effects or fruits follow, or not. Those operations ...

\section{$44 \mathrm{~V}$}

please me, are pleasant to me and meritorious to you and fruitful, in the same way like you have won all those souls in fact for me and have led them back to me. From there followed a further thought that the Beloved wanted to reward those effects and fervent desires as if they were achieved, even though the effects did not follow always in and in all. Just as the Preachers and Confessors and other workers in the vineyard of the holy Church were not frustrated by their merits and by the wages for their labors, which they ... to win souls, even though in fact few are won for God. As long as they do as much as they can, operating and laboring with a sincere and pure intention for God, with zealous effort, only driven, directed and motivated by love for God and their neighbor there, for proceeding so he has gained full wages for his perfect will and love. I understood this very clearly with great assurance and certainty of the truth.

With greater certainty it was brought back to my mind what the Beloved had once responded to St. Gertrudis in a similar case when she placed her complaint before him, that she didn't always see the actual fruits that followed from her zealous desires of that kind, from the fervent feelings of love and from the similar loving operations of the spirit of love, by which she was led directly. For it was said to her inside: even though I seem not to bring forth fruits from those things, I am pleased in them and it gives me delight when I see that those good desires and movements of love are operated so.

$81 \quad$ I.e. Saint Gertrude of Helfta. 
Spiritus amoris habens libertatem mire in ea operatur, et / subito ab ea exit uirtus ad omnes mundi partes, in Hollandiam, / ..d exercitum Gallorum. etc. /

Statim ....[sp]iritui amoris dabam locum, ipse incipiebat ualde ingeniose industrie, / [25] et amorose operari modo tam suauifluo, quasi intus et foris diuino influxu / fuissem possessa; omnia, quae erant intra me, cooperabantur huic amori; / omnes . animae potentiae, cor et animus, quasi dissoluebantur, aperiebantur; et / in libertatem afferebantur, modo quodam, quem nescio explicare; omnis / sanguis, et corporis uenae etiam uidebantur amori cooperari. / [30] Tunc uidebatur subito et subtiliter uirtus aliqua de me exire, quae in / instanti sese uidebatur dispergere, et peruolare omnes mundi partes, ubi / ...... aliqua .... itas animarum, quas Deus uolebat iuuare et aliqua gra- / tia .....re. / Hab........ in animo, qui diuersimode egebant gratia Dei, spi- / [35] [ritus] ..... amicabiliter excipiebat, sonebat, amplexabatur etc. unum / ......que suo modo, secundum exigentiam necessitatis, in qua erant constituti / .....cuti amantissimae, suauissimae, et amabilissimae Matres solent facere. /

In Polonia, in Hollandia, in exercitum Gallorum etc inueniebat spiritus / amoris abun..., quod ageret, in multis maestis desolatis, derelictis pusillanimis, / [40] ........us, et miserabilibus animabus: haec omnia fiebant, cum uelocitate, etce- / .......... te uolando ulterius de uno ad alium, quasi ab aliquo deductus cum / .........tione personarum, in quibus operari oportebat; nam amor est uelox in / [op]erationibus, dum ei cum libertate spiritus licet operari.

haec scripsit / ........mbri 1672. //

$45^{r}$

[1] Post multos mysticos agones diuina gratia superatos, dat locum / igni amoris, qui in corde et spiritu ardens aliquando uidetur / sursum trahere omnes animas extra Deum in natura, et in / peccatis uiuentes. /

[5] Die 17 dicti mensis, post diuersas animae dispositiones, post multos agones et / mortes amoris, qui uno die diuersimode accidunt et adueniunt, ex parte maligni / spiritus, et partis inferioris, a quibus spiritus frequenter oppugnatur, et uariis / insidiis, et laqueis circumuenitur, ut sic in sua pura, intima, et 
The spirit of love having its freedom works in her and suddenly a strength comes out of her and spreads to all parts of the world, to Holland, to the army of the French etc.

At once ... I gave place to the spirit of love, it began to operate very ingeniously, industriously and lovingly in such a sweetly flowing way, as if I was possessed inside and outside by a divine influence. All that was inside me cooperated with this love. All powers of the soul, heart and mind, were sort of dissolved, were opened and brought to freedom, in a way that I cannot explain. All the blood and veins of my body also seemed to cooperate with love. Then suddenly and subtly some strength seemed to come from me, that seemed to spread instantly and fly to all parts of the world, where ... some ... of the souls, which God wanted to help and some grace ...

... in mind, that miss in different ways God's grace, the spirit ... received friendly, sounded, embraced etc. one ... in his way, according to the requirements of necessity, in which were constituted ... very loving, sweet and charming mothers use to act.

In Poland ${ }^{82}$, in Holland, in the army of the French etc. the spirit of love found abundantly ..., which acted, in many sad, desolate, abandoned, pusillanimous ... and miserable souls. All these things happened quickly, etcetera ... flying further from the one to the other, as it were drawn down with ... of persons, in whom it should operate. For love is quick in her operations, while she is permitted to operate with freedom of the spirit.

These things she wrote on ... 1672

\section{$45^{r}$}

After many mystical struggles in which she was overcome by the divine grace, she gives place to the fire of love that, burning in the heart and in her spirit, seems to draw all souls that live outside God in nature and in sin.

On the $17^{\text {th }}$ of that month after various dispositions of the soul, after many struggles and deaths of love, which happen and arise in any one day in different ways, from the part of an evil spirit and of an inferior part, by which the spirit is frequently attacked and is also surrounded by various treacheries and traps, so that in this way he is diverted and hindered in his pure, intimate and

82 Probably Maria refers to the Polish-Ottoman War (1672-76). 
immediata ad / Deum conuersione diuertatur, seu impediatur, ipse spiritus diuina uirtute, et / [10] gratia Dilecti adiutus, et confortatus transcendit omnia, et dat locum, ac age- / ndi libertatem igni diuini amoris, qui insolito, nobili, spirituali, et simul sensibili / modo, in corde et spiritu accenditur, et ardet cum stabili sursum-flammatione / ad Essentiam increatam, cum tranquillitate, et simplicitate, et tamen uiuaciter / et efficaciter, non intime. /

[15] Aliquando nonnihil impetuose, cum simultanea secum et sursum attractione / omnium animarum, quae extra Deum uiuunt in peccatis, in natura; in sensualita- / tibus, et inordinatis ad creaturas affectionibus: atque iste impetus amoris, et / zelus animarum uidetur etiam esse bene regulatus secundum inoperationem / diuini spiritus. /

[20] Docetur in dicta dispositione attendere, ut istum ignem amoris / passiue sinat ardere, sine propria operatione. /

Uidebar interius instrui, quod in huiusmodi dispositione, solummodo debeam atten- / dere, ut illum ignem amoris sinam passiue sursum-flammare et ardere quatenus / sic melius in me possit consumere omnem subtilem mixtionem, fu......ntum, / [25] uel adhaesionem ad aliquid extra Deum, uel quod Deus non est, uel .....Deiforme, / etiam ad dona, et fauores Dilecti, ne aliquid uel minimum spiritum a Deo / mediet, uel impediat. /

Item, quod debeam aduigilare, ut nihil accedat de propria operatione, uel / aliquid a parte inferiore ingestum, ut sic ille ignis amoris in sua puritate et / [30] nobilitate conseruetur, et sinatur operare secundum modum actualis tractus / Dilecti, cum plena libertate spiritus, dando amori plenum ..iirum /

Porro quando iste ignis amoris de nouo in me accenditur et operatur, tunc / iterum renouatur in me spiritus supradictae faecunditati... animarum, pro- / pensio, et effusio amoris erga easdem, qui amor ex am[an]te corde meo pro- / [35] fluens est mirabilis et ineffabilis. /

Uidetur tunc quod omnia interiora mea, et uiscera nihil sint aliud, nisi / oleum suauifluum effusum, seu balsamum diuinae benignitatis, clementiae / misericordiae, et dilectionis u.g. ad animas in Hollandia uel alibi conuerten- / das, ad desolatos consolandos, ad pusillanimes confortandos, ad miseros / [40] subleuandos in exercitu Gallorum, ad omnes animandos, et ad Deum / perducendos etc, idque cum insatiabili fame et siti, ut omnes Deo pariter / et Christo lucrifaciam. /

Spiritus amoris supercomplectitur, et supercomprehendit illos omn[es]/ [ta]nta charitate, amabilitate, zelo et feruore, ut prae teneritudine ... // 
immediate conversion to God. The spirit itself is helped and comforted by divine strength and the grace of the Beloved transcends all and gives place and freedom of acting to the fire of divine love, that is ignited in an unusual, noble, spiritual and at the same time sensible way in the heart and the spirit, and burns with a stable upward flame towards the uncreated Essence, with quietness and simplicity and yet vivaciously and forcefully, not intimately.

Sometimes somewhat impetuous, with a simultaneous attraction to itself and to on high of all souls which live outside God in sin, in nature, in sensualities and disordered feelings towards creatures. And that attack of love and zeal for souls seemed to be also well regulated according to the operation of the divine spirit.

She is taught in the aforementioned disposition to make sure to let that fire of love burn passively without her own operation.

I seemed to be instructed inside, that in a disposition of this kind, I only had to make sure that I let that fire of love flame upwards passively and burn so that it could better consume in me every subtle mixture, ... or attachment to anything outside God, or what is not God of ... Godlike, even to gifts and favours of the Beloved, so that not anything, even the smallest might repel or impede my spirit from God.

Likewise I must watch that nothing is added of my own operation or something applied by an inferior part, so that the fire of love is preserved in its purity and nobleness and is left to operate by way of and the actual drawing of the Beloved, with full freedom of the spirit, giving to love the full ...

Further when that spirit of love is ignited again in me and operates, then again the spirit of the aforementioned fertility is renewed in me ... of the souls, the propensity and effusion of love towards them. That love which flows from my loving heart is miraculous and ineffable.

It seems then that all my interior and my entrails are nothing but sweetflowing oil poured out or balm of divine goodness, clemency, mercy and love, e.g. to convert souls in Holland or elsewhere and to console those who are desolate, to comfort those who are pusillanimous, to support those who are in the French army, to animate all and to lead them back to God etc., and that with an insatiable hunger and thirst so as to win them all for God and for Christ.

The spirit of love includes and embraces them all with so much love, friendliness, zeal and enthusiasm that by reason of the tenderness ... 
[1] fere deficiam, et liquefiam; cor agitatur quasi cum spirituali quadam inqui- / etudine, absque tamen interruptione internae pacis, quietis, et tranquillitatis / animi. /

Renouatur in ea spiritus amoris erga Regem Galliae, qui, uti / [5] et Rex Hisp., sunt illi, ut duo filii, sed magis Rex Galliae, pro / quo periclitante iubetur diuinitus orare./

In mense februario 1673 , renouabatur in me spiritus amoris, et spiritualis / inclinatio nis, ac unionis erga Regem, et cum Rege Galliae: hic erat positus / in corde meo, et etiam Rex Hispaniarum, quasi ambo fuissent mei filii: spi- $/$ [10] ritus amoris habebat multa agenda cum Rege Galliae, sed non multum / attrahebat Regem Hispaniarum; uidebatur illum ex parte relinquere / inaduertenter, uelut filium, seu puerum dormientem. /

Item quadam nocte inter horam 12mam et 1am, ab aliquo quasi excitabar, / qui mihi dicebat, ora pro Rege Galliae; eodem tempore infundebatur mihi / [15] spiritus orandi; aliquo tempore post incidebam in somnum; circa horam 2am / iterum excitabar, et dicebatur, ut ante, ora pro Rege Galliae; aliquam diu post / rursus obdormiebam, et pro za uice excitabar, et mihi dicebatur, ut uidebatur, cum / maiori auctoritate, ora incessanter; unde suspicabar, et colligebam, quod Rex / uel eius exercitus esset in aliquo periculo. /

[20] Perseuerabam in oratione, circiter usque ad medium septimae matutinae, quando / uidebar intelligere, quod periculum transiisset, ex his uerbis: iam cessat peri- / culum, et non poteram postea amplius orare; hoc erat circa tempus, quo Ciuitas / N.... nsis erat obsessa a Gallis. /

.....r spiritu amoris et orationis pro Rege Galliae, ut Deus illum / [25] dominum harum Prouinciarum, cum spe successus; et / uidet S. Ludouicum amicabiliter inclinatum ad hunc Regem. /

Circa idem tempus semel tenerrimo ferebar amore, et beneuolentia erga hunc / Regem, eo quod cum tanto zelo suam uitam et coronam Dilecto obtulisset ad / Hollandiam reducendam ad fidem catholicam; multum mouebar, ut supplicarem / [30] Dilecto meo, quatenus hunc Regis erga se zelum et amorem uellet per aliqui / remunerare et .... orare, n. ut ei complaceret istum facere 
(...) I fall and melt. My heart is driven as it were by some spiritual restlessness, still without an interruption of the inner peace, quietness and tranquility of my mind.

In her the spirit of love towards the King of France is renewed. He and the King of Spain are like sons for her, but particularly the King of France, for whom she is commanded to pray when he is in danger.

In the month February 1673 the spirit of love was renewed in me along with the spiritual inclination and union towards and with the King of France. He was placed in my heart and the King of the Spaniards also, as if they both were my sons. The spirit of love had much to do with the King of France, but did not so much attract the King of the Spaniards. He seemed to leave him mostly neglected, like a sleeping son or boy.

Likewise one night between 12 and 1 o'clock, I was awakened by something that said to me: "Pray for the King of France". In that same moment the spirit of praying was poured into me. Sometime later I fell asleep. About 2 o'clock again I was awakened and it was said like before: "Pray for the King of France". Sometime after that I fell asleep again and for the third time I was awakened and it was said to me, as it seemed with greater authority: "Pray incessantly". So I suspected and found that the King or his army was in some danger.

I persevered in prayer, until about the middle of the seventh hour in the morning, when I seemed to understand that the danger had subsided based on these words: "Already the danger is subsiding". And I could not pray after that. This was at about the time that the city ${ }^{83}$... was occupied by the French.

... by the spirit of love and of prayer for the King of France, so that God ... him lord of these Provinces, with the hope of success. And she sees St. Louis ${ }^{84}$ amicably inclined towards this King.

About the same time I was once moved by a very tender love and benevolence towards this King, because he had presented his life and crown to the Beloved with such zeal to lead Holland back to the catholic faith. I was so moved that I begged my Beloved, in order that he might wish to reward this zeal and love of the King towards him with something ... and to pray, namely so that it might

83 Unknown city.

84 I.e. Louis IX, King of France (1226-1270). 
Dominum et Regem / ........Prouinci....., in quem finem agebar, ut accederem ad sacram commu- / nionem ...... desiderati successus. /

In m.... Augustus 1673, in festo S. Ludouici Regis Franciae, in oratione / [35] ...umtum memini, post sacram communionem, percepi in spiritu, quomodo / ...e sanctus Rex offenderet aliquam amicabilem propensionem huic mo- / derno Regi; id quod me faciebat sperare aliquid magnum super illum, et de illo. /

Intelligit plures esse pro Rege Galliae, quam contra; iubetur / maledicere aduersariis Gallorum; uidet Deum iratum Impera- / [40] tori et Hispanis ob suppetias datas Hollandis. /

.....lud tempus, quando per hanc Ciuitatem transibant multi milites /

......ut irent in subsidium haereticorum, multum inde contristaba.... /

......nt impeditur (;) pium et deiforme .....litum praedicti Regis ..... //

$46 r$

[1] mihi dicebatur interius consolata etc, quia plures sunt pro Rege, quam / contra Regem. /

Alio tempore, quando ob praedictum finem adhuc transibant milites, uide- / batur mihi mandari, ut illis maledicerem, et uerba maledictionis in illos / [5] pronunciarem, a qua suggestione multum perhorrescebam, et illam reiicie- / bam quasi a maligno spiritu prouentientem; uerum quanto magis reiiciebam / et reprobabam, tanto magis urgebar; ideo ad Dilectum meum conuersa, di- / cebam maesto et afflicto corde; Dilecte, si tu illis maledicas, ego etiam male- / dico, sed rogo, ut illa maledictio tantum cadat super corpora, et non super ani-/ [10] mas illorum; sic cessabat pressura, nec urgebar amplius, et manebam quieta. /

Circa istud tempus, semel mane euigilans, sentiebam mentem meam om- / nino turbatam, eo quod Dilectus meus, sese per impressiones in anima mea / ostenderet ualde offensum et iratum, quia Imperator mittebat tot copias mili- / tum in subsidium haereticorum, et quantum in se erat, uolebat impedire honorem / [15] et gloriam Christi, et salutem tot animarum. /

Dilectus uidebatur ipsi minari aliquas plagas, non quidem ipsius personae, sed / ipsius regno, aliquam illius diuisionem per aliquos eius aduersarios, et quod / Hispania etiam participaret: habebatur etiam adscriptum hoc modo; non sum / certa, quod hae omnes fuerint illuminationes supernaturales; eo 
please Him to make him lord and King ... Province ... to which purpose I was led, so that I might go to holy communion ... of the desired success.

In the month of August 1673, on the feast of St. Louis the King of France, ${ }^{85}$ in prayer ... I remembered after holy communion, I perceived in the spirit how ... the holy King experienced a friendly propensity towards this modern King. This made me hope for something great for him and from him.

She understands that there are more in favour of the King than against him. She is commanded to curse the opponents of the French. She sees that God is angry with the Emperor and with the Spaniards because of the support they have given to the Dutch.

... that time, when through this city went many soldiers

... they went to the help of the heretics, therefore was much saddened ...

... was hindered ... pious and Godlike ... of the aforementioned King...

$46 r$

was said to me consoled within etc., because there are more in favour of the King than against the King.

Another time, when because of the aforementioned purpose soldiers still passed, it seemed that I was asked to curse them and pronounce curses against them, by which suggestion I began to shiver much and I rejected that as if it came from an evil spirit. But the more I rejected it and disapproved of it, the more I was urged. Therefore turned towards my Beloved, I said with a sad and afflicted heart: Beloved, if you curse them, I also curse them, but I ask, that that cursing fall only over their bodies and not over their souls. So the pressure ceased and I was no longer urged and I remained quiet.

About that time, once awakening early, I felt my mind totally disturbed, because my Beloved showed himself by impressions in my soul very offended and angry, because the Emperor sent so many military troops to the help of the heretics, and as much as he could, he wanted to impede the honour and glory of Christ and the salvation of so many souls.

The Beloved seemed to threaten him with some misfortunes, not only to his own person, but also to his empire, some division of it by some of his opponents, with Spain also participating. It was added in this way. I am not certain that all these things were supernatural illuminations, because natural reason

$85 \quad$ See n. 84 . 
quod ratio / [20] naturalis facile possit formare argumentum ex apparentiis externis, et de / iudiciis, quae ratio potest inuestigare et assequi de aliquibus rebus, quas uidit, / audiuit, et considerauit, u.g. quia ratio facile potest iudicare, quod I[mper]ator / etc operaretur contra Deum, et quod Deus id non relinqueret impunitu[m]./

Uidet in Deo conflictum duorum exercituum, et [Gall]os / [25] habere uictoriam, et occupaturos Hollandiam. /

Circa idem tempus, cum uacarem oratione, uidebar esse rapta in spiritu, et in / Deo uidere, et (ut dicitur) legere, quod duo exercitus contra inuicem appro- / pinquarent, et inter se configerent, et quod Galli in hoc conflictu reportarent / uictoriam, et quod Rex Galliae occupabit Hollandiam. /

[30] Haec uisio huius rei futurae, in Deo, erat talis, qualis in Prophetis, quando / aliqua futura prouidebant, prout ab anno, uel circiter [quas]i fuit demonst[ra] / tum, et insinuatum, quomodo futura uideantur, et sciant, ...ut ...ntia, quae / procul dissita, ut propinqua; quia .... Deo omnia praeterita et futura sunt / praesentia, atque Deus est nobis proximus et ualde intime praesens, ergo omnia / [35] quae sunt in Deo, sunt etiam hoc sensu nobis proxima, et intime praesentia, atque / ut sic immediate uidentur et cognoscuntur in Deo uelut uitrum, quod a splen- / dore solis ab omni parte est pellucidum, et penetratum etc. /

Intelligit Deum ualde male capere, quod Religiosi grauentur / gabellis, et pecunias illis potius obfuturas, uti suo tempore patebit. /

[40] Alias, quando Domini statuum Patriae Religiosis auferebant sua priuilegia et ... / ciebant illos contribuere et soluere uecticalia, sicut saeculares, et quadam / spernebant orationes religiosorum pro prosperitate nostri Regi ... / .... in..et pecuniis etc, magis fidendo .... //

$46 v$

[1] contra ius cogebat illos soluere, quam orationibus etc, mihi per intimas im-/ pressiones, et alias perceptiones internas uidebatur significari quod 
could easily form an argument from external appearances and from judgments, which reason can investigate and understand from the things, that it has seen, heard and considered, e.g. because reason can easily judge that the Emperor etc. operates against God and God cannot leave that unpunished.

She sees in God the conflict between the two armies, and that the French will have the victory and will occupy Holland.

About that same time, when I was devoted to prayer I seemed to be seized in the spirit, and to see in God and (as it is said) to read, that the two armies drew nearer to each other in battle and pierced one another and that the French in that conflict brought back the victory and that the King of France would occupy Holland.

This vision of this future event, in God, was such as it was in the Prophets, when they foresaw some future things, like one year ago or thereabout, as if it had been demonstrated and insinuated how the future would be, and they know ... that ... which are far away, like they are near. Because ... in God all past and future things are present and God is very near to us and very intimately present, so all things that are in God are also in this sense very near to us and intimately present, and like that, they are seen and known immediately in God like in a glass that by the splendor of the sun is transparent and accessible from each side etc.

She understands that God takes it very badly that the Religious are overburdened by taxes, and that the money they handed over will rather in its own time injure them.

Another time, when the Lords of the states of the Country took from the Religious their privileges and ... them to contribute and pay taxes like seculars ${ }^{86}$, and somewhat rejected the prayers of the religious for the prosperity of our King ... in ... and money etc, rather trusting ...

$46 v$

against the law forced them to pay, which by prayers etc, by intimate impressions and other inner perceptions seemed to be signified to me, that the

86 Perhaps Maria refers here to an ordinance announced by Count de Monterrey on the 1st of June 1672, see the Derden placcaet-boeck van Vlaenderen (1685) 37. 
Dilec- / tus id ualde male caperet, mihi significando, quod ista pecunia ipsis non / prodesset, uel ad aliquid proficeret, sed potius obesset, et noceret; prout patebit / [5] suo tempore, quando uidebunt, quantam benedictionem et uictoriam / Deus dabit Regi Galliae, eo quod ipse maiorem fiduciam posuerit in orationibus / famulorum et famularum Dei, illas humiliter et desideranter postulando / ad suum pium intentum; quod illi a Dilecto concessum est, prout ab effectu / satis patet, et mihi notum est, quomodo Deus aliquas animas moueat, et / [10] specialiter inoperetur, ut hunc Regem per suas orationes iuuent in suis / armis, et qualem ipse inde habeat prosperitatem, et quales progressus faciat / quia magis Deiformiter agit, et Religiosos, ac statum Ecclesiasticum magis / reueretur, quam hi nostri Domini modo faciunt. /

Multipliciter, mirabiliter et diuine agitur, et monetur ut / [15] oret pro Rege Galliae. /

Ego misera peccatrix debui illo tempore multum orare pro Rege Galliae, / et adhuc debeo modo orare pro prospero successu armorum ipsius / tunc temporis spiritus Dei, singulariter in me operabatur quemdam orandi modum / quem hic refero; spiritus meus uidebatur sursum eleuatus et attractus ante / [20] faciem Dei, et procumbebat pronus ante pedes diuinae maiestatis (nostro / humano modo loquendi et intelligendi) nam Deus non habet manus, uel / ped[es], uel aliquam speciem, aut formam, sicut homines, aut aliquid aliud. /

.....ut melius dicam, meus spiritus erat depressus, et demersus in / aliqu..... li profunditate, amictus lumine, seu Clara notitia essentialis / [25] suae m....tis coram incomprehensibili maiestate Dei; et una accensus / feruente [et a]rdente amore, absque formatione uerborum, uel sensus, faciebat / assiduas instantias ad cor diuinum, illud urgendo, quasi Deus permisisset se / a meo spiritu superari, et amorose cogi; non eram ego, quae sic orabam, sed / spiritus Dei in me. /

[30] Aliae particularitates istius orationis iam mihi non occurrunt, quia / iam circiter a octo mensibus ista contigerunt. /

Aliquando ..... ista oratio per uehementem et uigorosam appressionem / seu imp...... itat ad cor diuinum, non cum propria actiuitate, uel / per pro..... nem, sed ad hoc actus, seu diuinam inoperationem / [35] ........atiens; et ideo talis oratio me numquam fatigabat, etiamsi durasset / integris diebus /

Ob tristia nuncia de uictoria Hollandorum contra Gallos, tota deso- / lata, quasi sine spe etc spiritu rapitur in Deo, et toto die intime / spiritu et corpore roborata fruitur ferculis ex mensa sanctorum. / 
Beloved took it very badly, indicating to me that that money would not benefit them, or be of any use, but would rather in its time injure them, as in time will be clear, when they will see what blessing and victory God will give to the King of France, because he has placed more confidence in the prayers of the male and female servants of God, asking them humbly and earnestly for this pious intention. That is granted to him by the Beloved, as is clear enough from the effect and it is known to me how God moves some souls and especially operates in such a way that with their prayer they help this King with his weapons and with the kind of prosperity he has from that and the kind of progress he makes, because he acts in a more Godlike way and respects the Religious and the state of the Church more than our people do at the moment.

In many ways, miraculously and divinely she is led and admonished to pray for the King of France.

I poor sinner had to pray at that time much for the King of France and still I must pray so for the prosperous success of his weapons. Then at the time the spirit of God operated in a particular way in me with some manner of praying that I refer to here. My spirit seemed to be elevated upwards and attracted before the countenance of God and knelt down low before the feet of the divine majesty (in our human way of speaking and understanding), for God has no hands or feet or any appearance or form like humans, or anything else.

... that I rather say, my spirit was depressed and sunk in some ... depth, clothed with light or with a clear knowledge of his essential ... in the presence of the incomprehensible majesty of God. And at the same time ignited by a fervent and burning love, without the formation of words or senses, my spirit made constant intercessions to the divine heart, urging that, as if God had permitted that he could be lovingly coaxed and overcome by my spirit. It was not I, who prayed like this, but the spirit of God in me.

Other details of that prayer do not occur to me anymore, because those things happened already about eight months ago.

Sometime ... that prayer by a severe and vigorous pressure or impact ... on the divine heart, not through its own activity, or by ..., but led to this or ... a divine operation ... and therefore such prayer doesn't ever fatigue me, even if it should last for whole days.

Because of the sad reports about the victory of the Dutch against the French, totally desolate, as it were without hope etc, she is swept up in God and the entire day intimately strengthened in spirit and body she enjoys the dishes from the table of the saints. 
[40] ...... uigilia purificationis D. uirginis 1673 , quando Reuerentia Vestra mihi referebat /......ta tristia et mala nuncia de Hollandia, quomodo haeretici cum Caesar- /.....intercepissent Ciuitatem monasteriensem, Groeningam etc, et om... /..........lans crudeliter mactassent, uel pessime tractassent .......... |................... /|

$47 \mathrm{r}$

[1] absque ulla spe, quod Galli occuparent Hollandiam iuxta quod mihi uidebatur / promissum; eo quod humanitus loquendo, hoc iam uideretur esse extra omnem / apparentiam propter potentem trium exercituum resistentiam. /

Ipso festo D. Uirginis, incipiendo ab oratione matutina, erat meus spiritus / [5] introsumptus in Deo, et toto illo die manebat ualde intime tractus cum / actuali quiete in Deo; totum illum diem transigebam in continua oratione / quietis, et introtractionis, facile quinque horis consequenter, absque ulla fa- $/$ tigatione corporis aut animae, econtrario corpus et anima per illam orationem / quasi nutriebantur, et confortabantur, magis quam aliquis ex opiparo / [10] conuiuio; eo quod mihi apponerentur aliqua fercula de mensa sanctorum, / quae fercula uerbis exprimere nequeo; fruebar etiam nutritiua quiete et / nutritiuo amore, cum exigua perceptione dispositionis corporalis. /

Intimius introtracta fruitur praesentia Dilecti, qui eam amplexatur / et consolatur, assecurans sparsa nuncia esse falsa, et Regem Galliae/ [15] triumphaturum in Hollandia, in quem finem accipit spiritum orandi. /

Ante et post sacram communionem, aliquo tempore adhuc profundius in- / troducebar, et introtrahebar; ubi praetenere, ualde intime, suauiter et proxime / fruebar praesentia Dilecti, modo singulari, qui me ualde amicabiliter uide- / batur tractare, amorose amplexari et dulciter consolari, de dolore, afflic- / [20] tione, et uulnere amoris, quo pridie propter praedicta nuncia fueram sau- / ciata et angustiata. /

Dilectus mihi dicebat (tamen sine strepitu uerborum) per instinctum, seu / notificationem ualde intimam, et occultum, sponsa mea, sis c[ertifica]ta / 
... on the eve of the purification of the Virgin of God $1673^{87}$, when Your Reverence referred to me ... sad and bad reports about Holland, how the heretics with the imperial ... have taken the city of Münster, Groningen ${ }^{88}$ etc, and all ... have slaughtered cruelly or have treated very badly ...

\section{$47 \mathrm{r}$}

without any hope that the French might occupy Holland according to what seemed to be promised to me. Because humanly speaking, this seemed to be already beyond all appearance because of the powerful resistance of three armies. $^{89}$

On the same feast of the Virgin of God, beginning with morning prayer, my spirit was drawn into God and the entire day it remained very intimately centred with quietude in God. I passed that entire day in continuous prayer of quiet and inwardness, easily five hours consecutively, without any tiredness of body or soul, on the contrary, body and soul were as it were nurtured through that prayer and comforted, more than someone might be by a sumptuous banquet. Because some dishes were placed before me from the table of the saints, which dishes I cannot describe in words. I enjoyed also the nutritious quietness and nutritious love, with only a small perception of my corporeal disposition.

More intimately drawn inwards she enjoys the presence of the Beloved, who embraces and consoles her, reassuring her that the reports that have been spread are false and that the King of France will triumph in Holland, for which purpose she receives the spirit of praying.

Before and after holy communion, I was still for some time led deeper and drawn inwards. There, very tenderly, intimately and amicably, he embraced me lovingly and consoled me pleasantly for the pain, the affliction and the wound of love, by which I had been wounded and frightened because of the aforementioned reports.

The Beloved said to me (still without the sound of words) by an intuition or a very intimate and hidden notification: "My bride, be assured, your son the

\footnotetext{
$87 \quad$ 2nd February

88 The Bishop of Münster besieged the city from 21 July till 17 August 1672.

89 Probably Maria refers to the armies of the German Emperor, the Spanish and the Elector of Brandenburg.
} 
filius tuus Rex Galliae triumphabit in Hollandia; et mihi uideb...., quod / [25] mala nuncia superius relata non essent uera, praesertim de .....te mo- / nasteriensi; habebam omnino aliam cognitionem, et melius ...e testimo-/ nium, cum magna securitate et pace. /

Aliquot diebus postea, Reuerentia Vestra mihi rursus confirmabat praedicta nuncia / utpote non melius informata; quare deposita mea opinione, diffidebam prae- / [30] tactae internae testificationi, ac cognitioni; sed accedens ad orationem, iterum / continuabar sicut ante, quod ista non essent uera. /

Die quinta eiusdem mensis, sub oratione uespertiua mi..... bito aboriebatur / insolitum magnum lumen, et diuina claritas, quae me ......i unde ........ / ...lustrabat, et circumfulgebat, ac me ponebat in ........, et / [35] assecuratione, quod Rex Galliae triumpharet in Hollandia .... omnibus, / qui illi resistebant; adueniebat mihi etiam spiritus orandi pro faelici $\mathrm{p}[\mathrm{ro}-\mathrm{r} /$ gressu, et illius assistentia cum uehementi ardore diuini amoris. /

Spiritus orabat ualde efficaciter et feruenter cum magna reuerentia, / amore, et humilitate inclinatus, et prostratus coram diuina maiestate, una / [40] etiam agebar spiritu Deum laudante et benedicente, eo quod tam mirabi.... / uelrer cum hoc Rege cooperari ad promotionem S. Ecclesiae et salutem [ani-] / marum. /

Sic ibam cubitum; mane euigilans, sentiebam cor ualde accensu.... / ...ns in diuino amore, modo mirabiliori, quam umquam. //

\section{$47 \mathrm{~V}$}

[1] Possidetur a spiritu Dei, qui eius spiritui unitus incipit miro et / supernaturali modo cum eo occupari in fauorem Regis Galliae in / eius exercitu, dispergens se super totum exercitum. /

Secundum omnem apparentiam et experientiam, possidebar tunc a spiritu / [5] Dei, quod fiebat quasi per suauem et simul potentem superationem et / absolutam introsumptionem mei spiritus in spiritu Dei, spiritu me sic uoluntario / possesso; incipiebat spiritus Dei in illo, et cum illo mirabiliter cooperari, / modo raro, numquam antea probato, et supernaturali, n. pro assistentia et / adiutorio Regis Galliae in eius exercitu, ad confortandos milites etc, in quem / [10] finem distincte percipiebam, quod diuinus spiritus cum meo coniunctus et / unitus (nam hi duo tunc tantum erant unus spiritus, et unum esse sine 
King of France will triumph in Holland." And it seemed to me ... that the bad reports which were given before, were not true, especially about ... of Münster. I had a totally different knowledge and rather ... testimony, with great certainty and peace.

Some days later, Your Reverence confirmed the previously mentioned reports for me again, although they were not better informed. That is why, after having laid aside my opinion, I doubted the previously experienced inner testimony and cognition. But going into prayer, again it continued in me like before, that those things were not true.

On the fifth day of the same month, ${ }^{90}$ during Vespers suddenly the uncommon great light and the divine clarity disappeared from me, that ... me ... from there ... enlightened and shone around me and placed me in ... and the assurance, that the King of France would triumph in Holland ... all, who resisted him. Also the spirit of praying for the fortunate progress and assistance of him came to me with an intense glow of divine love.

The Spirit prayed very fervently, very effectively and with great respect, love and humility bowing and prostrating himself before the divine majesty. At the same time I was also led by the spirit that praised and blessed God, because so miraculously ... to cooperate with this King for the promotion of the holy Church and for the salvation of souls.

So I went to sleep. Early in the morning awakening, I felt my heart aflame... in divine love, in a more miraculous way than ever.

\section{$47 \mathrm{~V}$}

She is possessed by a spirit of God, that united with her spirit begins in a wonderful and supernatural way to be occupied in favour of the King of France with his army, spreading themselves over the entire army.

According to all appearance and experience I was possessed then by a spirit of God. This happened as by a sweet and at the same time powerful overcoming and total drawing of my spirit into the spirit of God, after the spirit had possessed me so voluntarily. The spirit of God began to cooperate in him and with him miraculously in a strange and supernatural way, never before tested, coming namely to the assistance of the King of France in his army, to comfort the soldiers etc., to which purpose I perceived distinctly that the divine spirit connected and united with mine (for these two were then only one spirit and one 
dif- / ferentia uel distinctione) se inclinaret, et dispergeret super istum exercitum, / ipsis communicando, in ipsos influendo, et effundendo aliquid diuinum, quantum / existimo, fortitudinem, sapientiam, et dilectionem. /

[15] Intelligebam, aliquod attentatum, uel conflictum esse prae manibus, et , ut / mihi uidebatur, de facto esse in fieri, eo quod Deus mecum, et ego cum Deo / tunc tam efficaciter cooperaremur multiplicibus modis, cum tam uiua per- / ceptione et certitudine, quod illae operationes spiritus essent diuinae, et quod / Deus esset cum isto Rege, et consequenter, quod in suis attentatis, assultibus, con- / [20] flictibus obtineret uictoriam, ut pro ista ueritate bene permisissem me comburi. /

Sperat per omnia prosperum successum istius Regis, quia spiritus / mire pro eo orat, et diuinam uirtutem illi et exercitui communicat, / ac a Deo iubetur illis benedicere, et aduersariis maledicere. /

Ista ... perceptibilis diuini spiritus meo spiritui uniti inclinatio ad illum exercitum / [25] faciebat me magna, bona attentata, et uictorias sperare, eo magis, quod spiritus tunc tam / singulari [m]odo in me oret, et ex Deo et ex me tam diuina uirtus exeat, et effluat in / Gallos; ..fien..i propter multiplices benedictiones, quas per internam directionem spiritus / illis frequenter impertior, apprecor, et illis a Dilecto etiam ultro concedi postulo, / econtra maledictiones secundum corpus imprecor aduersariis illorum, Deum depre- / [30] cando, ut ab illis auferat potestatem, sapientiam, animos et fortitudinem, neque ego / sum, quae sic oro, et postulo, sed spiritus Dei in me, per me, eo quod aduersarii Regis Galliae/ agant contra Deum; nam Dilectus commendauit, et donauit mihi Hollandiam. /

Durante eius a Deo possessione redit dispositio Reginae mandantis / cum potes[ta]te sibi a Dilecto concessa; tunc mandat Angelis, ut / [35] iuuent Dilectum ponere in regno suo, et iuuent Regem Galliae / qui se paratos. /

Quando eram in supradicta possessione, seu possessa a diuino spiritu, mihi iterum ad- / ueniebat ille animus, seu animae dispositio quasi Reginae mandantis, cum potestate, et / autoritate mihi a Dilecto infusa et concessa, imo cum suaui, et amicabili quasi / [40] ad hoc coactione, ita ut non uiderer aliter posse, prae uehementia spiritus, prae ex- / uberantia ardentis diuini amoris, prae spirituali ebrietate etc, quae tunc in me in- / ueniuntur. / 
being without difference or distinction) inclined and spread himself over that army, communicating to them, flowing into them and pouring out over them, as I believe, some divine force, wisdom and love.

I understood that some attack or conflict was pending and, as it seemed to me, that in fact was happening, because God with me and I with God cooperated then so strongly in multiple ways, with such a vivid perception and certainty that those operations of the spirit were divine and God was with that King and consequently that he would obtain victory in the attacks, assaults and conflicts, so that for that truth I allowed myself fully to be consumed.

Throughout all she hopes for the prosperous success of that King, because the spirit prays miraculously for him and extends divine power to him and his army, and by God she is commanded to bless them and to curse their opponents.

That ... perceptible inclination of the divine spirit united with my spirit to that army made me hope greatly, for good attacks and victories, the more because the spirit prayed then in such a particular way in me, and from God and from me went out a divine power that flowed into the French. ... because of the many blessings, which I through inner direction of the spirit frequently give them and pray for them and ask from the Beloved that those are also granted to them, and, on the contrary, I pray for malediction for the body for their opponents, asking of God that from them all might, wisdom, courage and strength be taken, and it is not I who is praying like that, but the spirit of God in me, through me, because the opponents of the King of France act against God. For the Beloved has entrusted and given Holland to me.

While she was possessed by God the disposition of a commanding queen returned with power that was granted to her by the Beloved. Then she commands the Angels that they help to place the Beloved in his kingdom and help the King of France, who ... ready.

When I was in the above-mentioned possession, or possessed by a divine spirit, again that spirit or disposition of the soul came to me as of a commanding queen, with might and authority infused and granted to me by the Beloved, yes even with a sweet and friendly sort of coercion, so that I seemed not to be able to do anything else, because of the heaviness of the spirit, because of the exuberance of the burning divine love, because of the spiritual inebriation etc., which were found then in me. 
Quo tempore cum singulari animi confidentia, et libertate, ago cum sanctis Angelis / ... mandando, ut fortiter agant, generose cooperentur, interceptas Ciuitates custo- / [45] ...nt, attentata et conceptus aduersariorum detegant, euertant etc, et omnia / .....disponant, prout res exigit, et est necessarium, ut Dilectus meus ibidem perfec- / .......stituatur, et stabiliatur in regno suo; ipsi Angeli exhibebant se ad into... / ....... zelosos, et promptos etc, mihi promittentes prosperitatem, et progr[essum] / .........um Regis Ga[lliae] //

\section{$48 r$}

[1] Dilectus dignetur mihi ignoscere, si in his errem, et de defectu sincerae humilitatis, / et de uana praesumptione sim culpabilis, audendo similia credere, et eloqui; ali- / quando simile quid uel solum cogitando, erubesco prae uerecundia, et humiliatione, / nempe, quando ista inoperatio transiit; sed spiritu redeunte, et iterum operante, / [5] ista formido, et erroris suspicio, ac uerecundia euanescit, quasi omnia essent bene. /

Iubetur a Dilecto annotare, quod Angeli apparuerint, ut iuuenes / accincti in corporali specie, et intelligit multa mala nuncia contra/Gallos esse falsa. /

Antecedenter sponte defui, et omisi scribere, quod modo ex parte Dilecti mei, uidetur / [10] mandari, ut scribam; quia eram nonnihil ambigua de ueritate, an imaginatio, et soler- / tia naturalis ibi non tantisper collusisset; uerum hodie uidebar aliter certificari, / nempe, quod Sancti Angeli sese exhibuerint promptos ad parendum meis mandatis / praetactis , et uiderim illos in specie Iuuenum, quasi accinctos ad iter: hae sunt primae / uices, quibus eos uidi in specie humana, et sic cum illis egi; ista uisio non diu durabat, / [15] ut mihi uidetur, non ultra duo Pater noster. /

Postea per diuersos intellexi, quomodo plura mala nuncia essent mendacia, et / econtra Galli fere occupauerint unam integram Prouinciam in Hollandia: sum / certa, quod Sancti Angeli ipsis praestent magnam assistentiam, et multum auxilientur / sed an sit uerus rumor de magna illa uictoria, non scio, nam de illa in spiritu / [20] nihil percipio.

haec in Februario 1673. /

Constituitur quasi Regina mandans a latere Dilecti, et mandat / angelis, ut assistant Regi Galliae, et eius exercitui in Hollandia. / 
In that time with a particular self-confidence and freedom, I speak with the holy angels ... ordering that they act forcefully, cooperate generously, watch over the conquered cities ... uncover and overthrow attacks and plans of the opponents, and dispose all ... insofar as it is required and necessary, so that my Beloved at the same place ... and is established in his kingdom. Those angels offered themselves to ... zealous and ready etc, promising me the prosperity and progress ... of the King of France.

\section{$48 \mathrm{r}$}

May the Beloved deign to forgive me, if I am mistaken in these things and would be guilty of the weakness of sincere humility and of vain presumption, daring to believe such things and to speak them out. Some time when I only even think something, I blush with shame and humiliation, namely when this operation has passed. But while the spirit returns, the suspicion of error and shame vanishes, as if all were good.

She is commanded by the Beloved to note that the angels have appeared like young men with a physical appearance and she understands that the many bad reports against the French are false.

Previously I have of my own accord failed and neglected to write what now seems to be demanded of me from the side of the Beloved that I write. I was somewhat ambivalent about the truth, due to imagination and natural ingenuity joining together. But today I seemed otherwise to be reassured, namely that the holy angels had offered themselves ready to obey my previously mentioned orders and I saw them in the form of young men, as it were girded for a journey. These were the first times that I have seen them in a human form and so I have spoken with them. That vision didn't last long as it seemed to me, not longer than two Our Fathers.

Then of different people I have understood how the very many bad reports were mendacious and that the French on the contrary had occupied one complete province in Holland. I am certain that the holy angels have given them great assistance and have much helped, but if that rumour about that great victory was true I don't know, for about that I perceive nothing in the spirit.

These things she wrote in February 1673.

She is placed like a commanding queen at the side of the Beloved and commands the angels to assist the King of France and his army in Holland. 
Quando diuinus spiritus me assumebat, infundebat spiritui meo diuinam quamdam / uirtutem, et alias cum ipso similitudines, et sic simul in unum, uidebatur diuinus / [25] spiritus et meus spiritus obumbrare Regem Galliae, et ipsi infundere aliquam / diuinam uirtutem, et alia dona, eumque sub suo comprehenso assumere. /

Uidebar iterum constituta in isto animo et dispositione Reginae mandantis; / cum perceptione, pro tempore ualde modico, circiter unius medii Aue, quod a Dilecto ... / uarer in spiritu, et ponerer iuxta eius latus, prout in anterioribus scriptis habetur. / [30] Inde iterum incipiebam mandare sanctis Angelis, ut Regi eiusque militibus / auxiliarentur, et praestarent assistentiam in promouendis negociis in Hollandiam, ad / honorem et gloriam Dilecti mei, et ad salutem animarum: o qualem confidentiam, / quantam spiritus libertatem experitur tunc anima mea in hoc negocio assumendo, / et prosequendo, quasi ad me pertinente, et mihi commisso! alie...e tamen magna / [35] perfundor uerecundia, et profunde demergor in nihilo meo cum adnihilatione / et stupore, quod Deus taliter mei meminisci, ac in me sic operari dignetur, quae ipsi / sum adeo infidelis in multis, et sum omnium indignissima. /

Haec dona nihil faciunt, nisi me deprimere, et profundius descendere in abyssum / uilitatis et nihileitatis meae; atque sic profundus descensus iterum causat maiorem / [40] eleuationem in Deo; quanto altius, tanto demissius, et quo demissius, eo altius; / tunc etiam mihi in memoriam reducebantur multae alteriores gratiae, uti dictu / est, cum securitate et certificatione ueritatis illarum. /

Dilectus ostendit se iratum Regi Galliae ob peccata dissimulata, et ... / minatur subtrahere manum auxiliutricem in Hollandia, quem i...../ [45] conatur placare, sed ipse renuit: ac uidetur cessare fauor caeli pr..... / 1673 et aliquot diebus praecedentibus, habui in spiritu multa ..... //

$48 v$

[1] impressiones, et alias perceptiones, quomodo Dilectus ostenderet male contentum / et iratum contra Regem Galliae, eo quod in suis subditis tolerasset et dissi- / mulasset multa mala, et grauia peccata, nec impediuisset, nec puniuesset; / intelligebam quod in his secutus fuisset humanas suas passiones, neglecto et / [5] seposito lumine gratiae, sibi a Deo concesso, ut illud sequendo, 
When the divine spirit took me up, he poured some divine power into my spirit and other similar things with that, and so at one and the same time the divine spirit and my spirit seemed to overshadow the King of France and to pour divine power into him along with other gifts, and to take him in their protection.

I seemed to be placed again in that mind and that disposition of a commanding queen, with the perception for a very limited time, about one and a half Ave Marias, that I was ... by the Beloved in the spirit and was placed at his side, as it is maintained in previous writings. After that I began again to order the holy angels to help the King and his soldiers and provide him with assistance in promoting his business in Holland, to the honour and glory of my Beloved and for the salvation of souls. $\mathrm{O}$ what confidence and how much freedom of spirit my soul is then experiencing in taking up this business and proceeding with it, as if it is -pertaining to me and entrusted on me! ... still I am plunged in great disgrace and deeply sunk in my nothingness with annihilation and stupor, that God deigns to remember me so and work in me in this way, who am so unfaithful to him in many things and most unworthy of all.

These gifts do nothing but dishearten me and lower me deeper into the abyss of my unworthiness and nothingness. And so the deep descent causes again a greater elevation in God. How much higher that much deeper and how much deeper, that much higher. Then also many deeper graces were brought back to my memory, as it is to say, with certainty and certification of the truth of those things.

The Beloved shows himself angry with the King of France because of his concealed sins and ... threatens to withdraw his helping hand in Holland, which ... tries to appease, but he refused. And the favour of heaven seems to cease for ...

... 1673 and some previous days, I have had in the spirit many ...

$48 v$

Impression and other perceptions, how the Beloved showed himself unhappy and angry with the King of France, because he had tolerated and concealed many serious and weighty sins among his subjects and had not impeded or punished them. I understood that he had followed his human passions, while the light of grace, that God had granted him, was neglected and set aside, so that if he had followed that light, he would have preserved among his people 
in populo suo ser- / uaret sanctum quemdam uehendi modum, secundum exemplam S. Ludouici Regis Galliae. /

Uidebatur Dilectus uelle subtrahere manum auxiliatricem in prosequendis uic- / toriis in Hollandia, quasi Rex se illa manu auxiliatrice indignum redderet. /

Id summopere sentiebam prae teneritudine affectus in amore Dilecti confide- / [10] rando in hoc eius interesse etc; magnopere occupabar, et me totam impendeba.. / ut Dilectum super hoc placarem, et isti Regi propitium redderem per actus contri- / tionis, per orationes, per gemitus, et intimas lamentationes nomine istius / Regis, quatenus Dilectus ipsi hanc noxam dimitteret, et eum dignaretur assu- / mere, sicut prius; sed Dilectus uidetur se exhibere quasi implacabilem, quasi / [15] renueret exaudire, sed spiritus orandi econtra non cessat illum deprecari. /

Circa hoc tempus amisit ille Rex conflictum in mari contra haereticos, etsi / de eo nihil scirem, dum praedicta in me transibant, nisi aliquo tempore post, quando / illud referri audiebam; de quo non mirabar, nec turbabar, quia nihil minus / exspectabam, attentis comminationibus Dilecti. /

[20] Adhuc aliquoties pro ipso oraui, magis ex proprio meo spiritu quam aliter, / ide..que sine efficacia, sine accessu, sine confidentia, et sine exauditione; uidebar / pulsare ad fores unius surdi, et quasi cortina aliqua fuisset interposita, ne/ uiderem, uel perciperem aliquid boni, uel aliquid pro ipso fauorabile apud Di- / lectum; omnis bona apparentia, et prosperitas, ac fauor caeli uidebatur inuersus / [25] et auersus; in quo debebam me uoluntarie resignare, totum diuinae dispositioni / committere, et annihilare in uoluntate Dei. /

Agitur miro spiritu orandi pro Rege Galliae, et Dilectus facit / eam pro illo pati, sicut alias pro illo fecit orare. /

... aliquam ualde penalem dispositionem, iterum percepi spiritum Dei in me / [30] ...ari, et tunc etiam incipiebat ille spiritus in me orare pro Rege Galliae, supra / [om]nem modum, et intellectum, sine uerbis et sine cogitationibus. /

Hic orandi modus est plane absconditus, et paucis notus; anima nihil ibi addi... / .... suo, sed solum .... titur, et sinit spiritum Dei in se orare; tantummodo debet attend[ere] / ut eum non inte.... et, aliquid de suo miscendo; sed se in sancto otio, ac in tranquil- / [35] litate .......... illi dare libertatem agendi. / 
some holy way of acting according to the example of St. Louis, the King of France.

The Beloved seemed to want to withdraw the helping hand he gave in the preceding victories in Holland, as if the King had shown himself unworthy of that helping hand.

I felt this above all because of the tenderness of the affection in the love of the Beloved trusting in this interest of his etc., I was very occupied and felt that it all depended on me to appease the Beloved over this, and to give the favour back to that King by acts of contrition, by prayers, sighs and intimate lamentations in the name of that King, in order that the Beloved would let go this transgression of his and would deign to take him up, like before. But the Beloved seemed to hold himself implacable as if he refused to hear, but the spirit of praying on the other hand did not cease to pray to him.

About this time that King lost the battle at sea against the heretics, ${ }^{91}$ though I knew nothing about that, while the above-mentioned things were going on in me, except some time after, when I heard the report. About that I did not wonder nor was I disturbed, because I expected nothing less, after I had heard of the threats to the Beloved.

Still several times I have prayed for him, more from my own spirit than otherwise ... without force, without access, without confidence and without being heard. I seemed to knock on the door of someone who is deaf, and as if some curtain had been placed between us, so that I could not see or perceive anything good or anything favourable for him in the Beloved. Every good appearance and prosperity and favour of heaven seemed to be inverted and turned away and so I had to resign voluntarily and commit myself totally to the divine disposition and become nothing in the face of the will of God.

She is led by a wonderful spirit of praying for the King of France, and the Beloved makes her suffer for him, like he has made others pray for him.

... some very painful disposition, I have perceived again the spirit of God in me ... and then also that spirit began to pray in me for the King of France, beyond every way and intellect, without words and without thoughts.

This way of praying is obviously hidden and known to few. The soul ... there nothing ... but only ... and let the spirit of God pray in it. It only has to take care that it ... him not ... and something of itself intermingling. But itself in holy rest and in quietness ... giving to him the freedom to act.

\footnotetext{
$91 \quad$ Maria refers here to the naval Battles of Schooneveld on 7 June and 14 June 1673.
} 
Quando hoc sic fit, tunc anima a spiritu Dei possidetur; spiritus superior animae / ..... diuinam illuminationem instructus separat se a spiritu inferiore, et uni- / to cum spiritu diuino, et ita orant simul in uno; haec oratio erat pro Rege Galliae / sed durabat modico tempore. /

[40] Mane euigilans, inueniebam me denuo in interiori afflictione, pressuris, an- / [gu]stiis etc quasi perfusam, post aliquantulum temporis incidebat mihi quidam / [inst]inctus cum illecebrosa cognitione, sicuti praeterito anno pro isto Rege orasti, ita / .... pro illo debes pati, a me quasi requirendo bene essem parata pro illo / .....sustinere, ad quod me statim praesentabam, me offerendo ad omne D... / .....ne placitam, etiam ad tolerandos poenas ... afflictiones infer...... /

[1] Agitur spiritu orandi pro Rege Galliae, quasi cogendo Dilectum, / ut eum iunet, cum fiducia exauditionis. /

Ab illo tempore uidebatur mihi interius accrescere suauior quaedam confidentia, / et fiducia, postulandi a Dilecto assistentiam et auxilium pro isto Rege, ut posset / [5] suis aduersariis resistere, et praeualere. /

Ante et post sacram communionem, cum essem spiritualiter Deo unita, id est / tota in spiritu, et abstracta ab omni sensu, in pura unitate, et nuditate, incipiebat / spiritus premere, et urgere Dilectum, imo quasi cogendo aggredi, ut uellet exten- / dere potentem manum suam ad iuuandum istum Regem, quatenus promissio a / [10] Dilecto mihi facta plenum sortiretur effectum; spiritus dicebat: Dilecte mi, / tu debes id facere, et mihi uidebatur, quod non amplius tergiuersaretur, uel / abnueret, et ex parte ad meam postulationem auscultaret, dando quasi confiden- / tiam perseuerandi in oratione, et in faciendis instantiis; ex quo sequitur praedulcis / fiducia instantis uictoriae. /

[15] Agitur spiritu orandi, et penitendi pro Rege Galliae, ut placet Dilectum, / cum impressione, quod conuertetur a suis peccatis. /

Die 28 Junii 1673, post sacram communionem sentiebam aliquam confidentiam, / et fiduciam ad deprecandum pro Delictis Regis, et Dilectum illi propitiandum; Item / agebar spiritu paenitentiae, contritionis, et confessionis eius nomine Dilecti faciendae, / [20] instar matris pro suo filio, cum praesentatione 
When this happens in this way, then the soul is possessed by the spirit of God. The superior spirit of the soul ... instructed by a divine illumination, separates itself from the inferior spirit and is united with the divine spirit, and so they pray together in one. This prayer was for the King of France, but lasted a short time.

Awakening early I found myself anew in inner affliction, pressures, anxieties etc, as it were overshadowed, after a little time some intuition fell on me with a seductive thought: "Like you prayed the previous year for that King, so ... you must suffer for him", requiring of me as it were that I be ready to sustain him ..., to which I presented myself at once, offering myself to all ... pleasing, also to tolerate punishments ... afflictions ...

\section{$49 \mathrm{r}$}

She is led by the spirit of praying for the King of France, as it were forcing the Beloved to help him, with the belief of being heard.

From that time on some sweeter confidence and faith seemed to grow within, to ask of the Beloved assistance and help for that King, so that he could resist and overcome his opponents.

Before and after holy communion, when I was spiritually united with God, that is completely in the spirit and abstracted from every sense in pure unity and nakedness, the spirit began to press and urge the Beloved, yes almost to approach him forcefully, so that he would extend his mighty hand to help that King, and so that the promise made to me by the Beloved would have full effect. The spirit said: "My Beloved, you must do that." And it seemed to me that he no longer turned his back on me or denied it, and from his side listened to my request, giving as it were confidence to persevere in prayer and in making intercessions. From this came a very sweet faith in the impending victory.

As it pleases the Beloved, she is led by the spirit of praying and of doing penance for the King of France, with the impression that he is converted from his sins.

On the 28th of June 1673 after holy communion I felt some confidence and faith to ask forgiveness for the offenses of the King, and to make reparation to the Beloved for him. Likewise I was led by the spirit of penance, contrition and confession made in the name of the Beloved, like a mother for her son, with 
pro ipso satisfaciendi utpote interius / ultro ad hoc mota, mere et pure ex zelo promouendi commune sanctae Ecclesiae bonum; / Item mihi infundebatur spiritus offerendi passionem, uulnera, et sanguinem Jesu/ ad placandum Deum, sicut mater solet agere causam filii apud Patrem, et delinquentem / filium offenso Patri studet reconciliare: fit etiam mihi quaedam quasi impressio, quod / [25] ille Rex deuenerit ad agnitionem, contritionem, confessionem, et sui ipsius humiliationem. /

Quando haec sunt transactae, et iterum ponor in paupertate, et carenti ..... omnium / perceptibilium, et sensibilium donorum Dei, in tenebris, in doloribus, [pr] essuris, et / angustiis, in parte inferiore; tunc excidunt mihi omnes praeteritae operationes .... / sic de isto Rege scriptae, omnia mihi tunc uertuntur in dubia, quod forte ..... / [30] proueniant ex naturali solertia, uel ab aliquo peregrino spiritu; eo magis, qu......... / postea me quasi sentio alienam ab isto Rege, et cum aliquali auersione ab illo, a ..... / ulla teneritudine affectus, uel amoris erga illum inclinatione, quae solummo[do] ...... / tam diu durat, quam diu illa operatio amoris etc in me est. /

$\mathrm{Ab}$ alia parte etiam mihi incidit, quod Dilectus meam praesentationem, et / [35] animi promptitudinem ad satisfaciendum pro illo, ratum habu[er]it et acceptauerit / et in istum finem me constituat in tam paenali animae statu; cum t...i suspensione / omnis sensibilitatis, gustus, solatii etc. secundum pariem superiorem et inferior[em] ... / et relinquar in totali et omnimoda derelictione, ualde dura, sensibili, eo magis ... / quia Dilecto permittente, pars inferior tunc est adeo sensibilis, et tam tenera ... / [40] aliquid sustinendum; ita ut uel minima contrarietas alicubi in aliqua re, uel / in aliquo obuia sit quasi uulnus in corde meo. /

Angustiae etiam et pressurae sunt tam sensibiles, ut mihi aliquando sudor eru.... / et ex re possim respirare, prae maerore, non sciendo, quare; quid sit de ueritate .... / Dilecto; uerum Lumen haec dispositio uidetur mihi ualde peregrina, quod sine .... / [45] ten........ sensibilis, usque ad ....criimas; uidetur mihi quod tunc sim posita .... / ................................................................................... //

49v

[1] Lumen fidei ad me exercendum in praesentia Dei, est plane spiritualis et a sen- / sibus abstractum. / 
the willingness to give satisfaction for him, as if I was voluntarily moved to this inside, merely and purely out of zeal to promote the common good of the holy Church. Likewise the spirit of offering the passion was poured into me, the wounds and the blood of Jesus to appease God, like a mother uses to plead the case of her son with the Father, and seeks to reconcile her wrongdoing son with the offended father. It happens also to me as if I also got some impression, that the King had come to acknowledgement, contrition and confession of his sins and some humiliation of himself.

When these things are done, and I am placed again in poverty and the missing ... of all perceptible and sensible gifts of God, in darkness, in pains, in pressures and anxieties, in an inferior part, then all the previous operations fail me ... so written about that King, all is turned into doubt for me, that strongly ... come forth from a natural ingenuity or some strange spirit. The more ... afterwards I felt sort of alienated from that King, and with some kind of aversion towards him, by ... some tenderness of feeling or inclination of love towards him, which only ... lasts as long as that operation of love etc. is in me.

On the other side it also occurred to me, that the Beloved had approved and accepted my willingness and the readiness of my mind to give satisfaction for him, and to that purpose he had placed me in such a painful state of soul, with the ... suspension of all sensibility, taste and solace etc. just like the upper and lower wall ${ }^{92} \ldots$ and I was left in total and complete abandonment, very hard, sensible, the more ... because while the Beloved permits it, my inferior part is then so sensible and so tender ... to sustain something, so that even the least contrariety, anywhere, or in anything, or in any matter comes to me like a wound in my heart.

I could feel the anxieties and pressures so much, that sometimes I broke out in sweat ... and I could just gasp out of sadness, not knowing why. What is the truth ... in the Beloved. But the Light seems in this disposition very strange to me, because without ... sensitive, to the point of tears ... it seems to me that I am placed then ...

49v

The light of faith that must be shone on me in the presence of God, is clearly spiritual and abstracted from the senses.

92 See article of Elisabeth Hense, 252-265. 
Ostenditur ei in spiritu malum imminens isti Regi, et exercitui illius, / quali Deus illis uellet maledicere, quod ipsa conatur deprecari, ac intelligit / [5] Deum isti Regi placatum, et eum adiuturum ad nouas uictorias. /

Die 29 Junii, festo Ss Apostolorum Petri et Pauli 1673 habui in spiritu aliquas / tristes repraesentationes de Rege Galliae, uidebatur capiti illius et toti exercitui / imminere ingens malum, perinde acsi quaedam maledictio super eum fuisset / comminata, nam Deus, imo totum caelum uidebatur faciem suam ab illo auertere, / [10] unde multum turbabar, consternabar et contristabar; confugiebam ad passionem, / ad uulnera et sanguinem Christi, ut possem comminatum, et mihi ostensum malum / deprecari. /

Post aliquid tempus apparebat in meo interiori quoddam diuinum bonum, seu / diuina maiestas, et accipiebam quasi confidentiam, et illecebram ad eamdem ado- / [15] randam; spiritus meus prouoluebat se ante pedes huius maiestatis, pronus super/ faciem suam in terra (nostro modo loquendi) et incipiebam cum magna humilitate / et amore, longo tempore exorare, supplicare, et postulare remissionem pro hoc / Rege, cum intimis gemitibus inenarrabilibus, Deo demonstrando omnia mala/ quae ex illa maledictione etc prouenirent; Item ut Deus dignaretur ipsius misereri / [20] et oculo misericordiae respicere ad omnem effusionem tam copiosi sanguinis innocentis / quem uidebam profundendum, casu quo commitrata maledictio fuisset sortita suum / plenum effectum; et ut Deus uellet misereri tot animarum, quae per hoc aeternalit.... / perirent; ut saltem uellet exaudire praetiosum sanguinem Unigeniti sui filii etc. /

Qui[b]us peractis, percipiebam pacem inter Deum et istum Regem esse factam, et / [25] Regem esse Deo reconciliatum; per diuinam quamdam irradiationem seu illumi- / nationem in fundo animae meae, pro certo cognoscebam, quod Rex deinceps iterum / haberet uictorias; non obstante, quod iam aliquo tempore passus fuisset cladem, / multos milites amisisset, et uideretur esse extra humanam spem, et apparentiam / ..... amplius obtinendi uictorias. /

[30] Fertur spiritu amoris erga Regem, et exercitum ante Traiectum, quam / ciuitatem clare uidet in Deo, cum assecuratione, quod Rex illam intercipiet / ministerio Angelorum, quorum auxilio postea intelligit eam interceptam. /

Rediebat mihi teneritudo amoris et maternus affectus erga istum Regem, sicuti anno / praeterito ; spiritu amoris iterum aderam Regi, et eius exercitui in 
To her is shown in the spirit the evil that threatens that King and his army, with which God wanted to curse them, because she tries to ask for their forgiveness and she understands that God is appeased concerning that King and that he will help him with new victories.

On the 29th of June on the feast the holy Apostles Peter and Paul 1673 I had in the spirit some sad representations about the King of France. It seemed that some huge evil hung over him and his entire army, as if some curse was threatening him, for God, yes even the whole of heaven seemed to turn away his face from him, therefore I was very confused, dismayed and grieved. I took my refuge in the passion, the wounds and the blood of Christ, so that I could avert the threat and the evil that was shown to me.

After some time inside me there appeared some divine good or divine majesty, and I received as it were a confidence and incitement to adore that same thing. My spirit hurried to the feet of this majesty, flat on its face on the ground (in our way of speaking) and I began with great humility and love to pray for a long time and to beg and ask remission for that King, with intimate and ineffable sighs, demonstrating to God all the evil that would result from that curse. Likewise that God would deign to remember him and look back with his merciful eye to all the spilling of so much innocent blood, which I saw that would be shed, in which case the threatened curse would have had its full effect. And that God wanted to have mercy on so many souls, who by this eternally ... perish. That he at least would hear the precious blood of his only begotten Son etc.

After these things had been completed I perceived that peace had been made between God and that King and that the King was reconciled with God. Through some divine irradiation of illumination in the depths of my soul, I knew for certain, that the King immediately again had lost many soldiers and it seemed to be beyond all human hope and appearance ... to obtain more victories.

She is animated by the spirit of love towards the King and the army before Maastricht, which city she sees clearly in God, with the assurance that the King will occupy it with the ministry of the angels, by whose help she understands later that that city is occupied. ${ }^{93}$

The tenderness of love and maternal affection towards that King returned to me, like in the previous year. With the spirit of love I stood again with the King

93 See n. 29. 
conflictu ante / [35] ciuitatem Traiectensem, ad eos inuandos, non dubitans, quin eam occuparent. /

Eodem die post meridiem uidebam in Deo, uelut in speculo, quod Ciuitas illa breui / traderetur; Deus ostendebat mihi istam ciuitatem in se cum tali claritate, sicut aliquid / uidetur in speculo, cum plena certitudine, quod Rex illam interciperet. /

Sequenti die, ultimo mensis, mane hora sexta, cum essem in uia ad templum, mihi / [40] subito oboriebatur aliquod extraordinarium lumen diuinum in supremitate spiritus / per modum stantis fulguris corruscantis, quod durabat circiter ad unum Aue / Maria, et sic disparebat. /

In hoc lumine, et per hoc lumen intelligebam et percipiebam Sanctos Angelos / ....isse in adiutorium et assistentiam Regis, cum praemagna certificatione / [45] [uer]itatis, et assecuratione, quod deinceps iterum haberet bonum successum / /.....o laetabar, et laudabam Dei misericordiam. // 
and with his army in the conflict before the city of Maastricht, with the invading troops, not doubting that they would occupy it.

On that same day in the afternoon I saw in God as in a mirror, that the city would be soon delivered. God showed me that city in him with such clarity, like something that is seen in a mirror, with full certainty, that the King would occupy it.

The next day, the last of the month, early in the sixth hour, when I was on my way to the church, suddenly some extraordinary light arose in the sublimity of the spirit in the form of a standing bolt of lightning, which lasted about one Ave Maria, and disappeared just like that.

In this light and through this light I understood and perceived that the holy angels ... to the help and assistance of the King, with a very great certainty of the truth and assurance, that he would immediately enjoy good success ... I was pleased and praised the mercy of God. 